UNIVERSIDADE DE SÃO PAULO

Faculdade de Filosofia, Letras e Ciências Humanas

BENIVALDO JOSÉ DE ARAÚJO JÚNIOR

\title{
As passivas na produção escrita de brasileiros aprendizes de Espanhol como língua estrangeira
}

Orientadora: Profa. Dra. Neide T. Maia González

São Paulo

2006 
A Beni e Tetê, meus pais. 


\section{AGRADECIMENTOS}

A Neide T. Maia González, que me guiou com sabedoria e segurança ao longo deste trabalho.

A Maite Celada, pela inestimável contribuição em sugestões e referências bibliográficas.

A Adrián Fanjul e Claudia Jacobi, cujas sugestões foram relevantes para a minha pesquisa.

Aos professores e alunos do Español en el Campus que possibilitaram a implantação do Banco de Dados/EEC ou contribuíram com esse projeto.

A Silvio Sato, amigo e companheiro, pela confiança e apoio. 
As construções passivas no Português Brasileiro e no Espanhol apresentam tanto tendências comuns, quanto assimetrias. Este trabalho tem o propósito de investigar os efeitos desse fenômeno na aquisição/aprendizagem de Espanhol por estudantes brasileiros. Inicialmente, propõe-se uma descrição das construções passivas nas duas línguas. Em seguida, faz-se uma análise contrastiva dessas construções no Português Brasileiro e no Espanhol. Finalmente, investiga-se o comportamento das construções passivas (sobretudo as perifrásticas e as lexicais) na produção escrita de brasileiros aprendizes de Espanhol língua estrangeira. Os resultados obtidos na análise dos corpora sugerem algumas hipóteses sobre os fatores que possivelmente influenciam a preferência dos aprendizes por determinadas construções em detrimento de outras.

Palavras-chave: construções passivas, análise contrastiva, lingüística de corpus, papéis temáticos, funções pragmáticas. 
Las construcciones pasivas en Portugués Brasileño y en Español presentan tanto tendencias comunes como asimetrías. Este trabajo tiene el propósito de investigar los efectos de dicho fenómeno sobre la adquisición/aprendizaje de Español por estudiantes brasileños. Inicialmente, se propone la descripción de las construcciones pasivas en ambas lenguas. En seguida, se hace un análisis contrastivo de dichas construcciones en Portugués Brasileño y en Español. Finalmente, se investiga el comportamiento de las construcciones pasivas (sobre todo las perifrásticas y lexicales) en la producción escrita de estudiantes brasileños de español lengua extranjera. Los resultados del análisis de los corpora sugieren algunas hipótesis sobre los factores que possiblemente influyen en la preferencia de los aprendices por determinadas construcciones en detrimento de otras.

Palavras clave: construcciones pasivas, análisis contrastivo, lingüística de corpus, papeles temáticos, funciones pragmáticas. 
Passive constructions in Brazilian Portuguese and Spanish present both common tendencies and assimetries. The aim of this project is to investigate the effects of such phenomenon on Spanish acquisition/learning process by brazilian students. Initially, a description of passive constructions is proposed for both languages. After that, a contrastive analysis is made of those constructions in Brazilian Portuguese and Spanish. Finally, the behavior of passive constructions is analyzed in the written production of brazilian students who learn Spanish as a foreign language. Results from corpora analysis suggest some hypotheses on the factors which possibly influence learners' choices for certain constructions to the detriment of others.

Keywords: passive constructions, contrastive analysis, corpus linguistics, thematic roles, pragmatic functions. 
SUMÁRIO

INTRODUÇÃO

009

OBJETIVO DO TRABALHO

013

\section{CAPÍTULO I}

As passivas no Espanhol e no PB .............................................. 014

I.1. Considerações preliminares .................................................... 014

I.2. Acerca das passivas no Espanhol ............................................... 018

I.3. Acerca das passivas no PB ...................................................... 032

I.4. As passivas no PB e no Espanhol: análise contrastiva $\ldots \ldots \ldots \ldots \ldots \ldots . . . . . . . .042$

I.4.1. Sobre a proposta de análise ............................................ 042

I.4.2. As construções predominantes no PB e no Espanhol ......... 042

I.4.3. A presença vs. ausência de agente na estrutura ................ 044

I.4.4. Paciente [+humano] vs. [-humano] .................................... 049

I.4.5. Caráter temático/ remático do paciente ............................. 050

I.4.6. Função das construções passivas ....................................... 053

I.4.7. Considerações finais ........................................................ 055

\section{CAPÍTULO II}

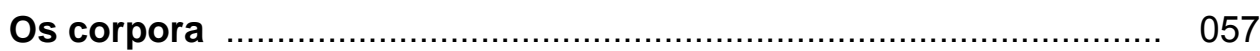

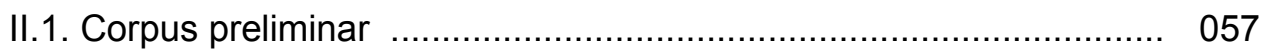

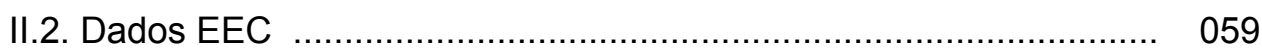

II.2.1. Os informantes ............................................................ 059

II.2.2. As produções ............................................................ 061

II.3. Levantamento das FVP nos corpora ............................................ 063

II.4. Os padrões esperados nos corpora ............................................. 068

\section{CAPÍTULO III}

Os resultados

071 
III.1. Os resultados obtidos e seus padrões de incidência $\quad$.................... 071

III.2. Classificação e inventário das FVP nos corpora ......................... 073

III.3. Análise das FVP de particípio ............................................... 077

III.3.1. O agente ............................................................. 077

III.3.1.1. PRESENÇA vs. AUSÊNCIA .............................. 077

III.3.1.2. AGENTE [+humano] vs. [-humano] ....................... 080

III.3.2. O paciente ............................................................. 082

III.3.2.1. PACIENTE [+humano] vs. [-humano] .................. 082

III.3.2.2. PACIENTE TEMA vs. REMA ............................. 084

III.3.3. A função das FVP .......................................................... 085

\section{CAPÍTULO IV}

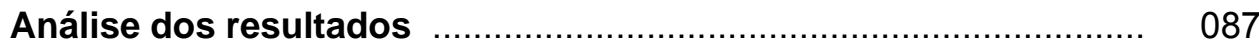

IV.1. Sobre o caráter marcado das FVP ......................................... 087

IV.2. Sobre a preferência dos aprendizes ........................................ 088

IV.2.1. A ordem SV na produção dos aprendizes ....................... 089

IV.2.2. A questão pronominal ................................................... 092

IV.2.3. A nominalização ..................................................... 098

CONCLUSÕES …................................................................. 100

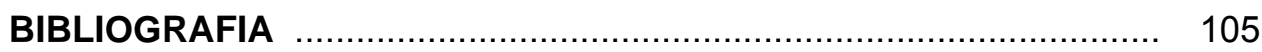

Referências bibliográficas …....................................................... 105

Bibliografia geral ......................................................................... 108

Livros didáticos e paradidáticos consultados .................................... 110

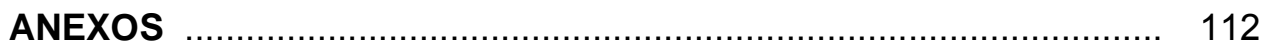

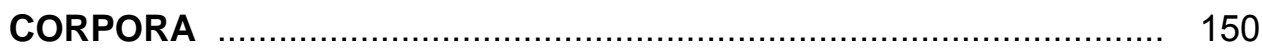

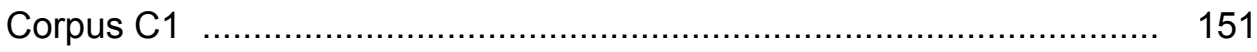

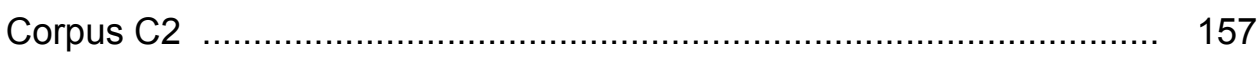


A minha curiosidade acerca das estruturas passivas vem desde a época em que eu era aluno do (hoje) ensino médio. Recordo que o tema aparecia nas gramáticas e nos livros didáticos de língua portuguesa dentro do item "vozes verbais", na seção dedicada à morfologia do verbo. Também era usual que fosse referido na sintaxe, ao tratar-se da oração e seus termos (dentre os quais, o "agente da passiva"). Nos dois casos, a abordagem das passivas era brevíssima e pouco divergia da que hoje está presente em publicações similares disponíveis no mercado brasileiro. Uma consulta a gramáticas (Bechara, 1976 e 1999, Cunha, 1990, Cunha \& Cintra, 2001, Luft, 1996, Sacconi, 1998, André, 1997), livros didáticos para o ensino médio (Neto \& Infante, 2004, Nicola \& Infante, 2004) e para o ensino fundamental ${ }^{1}$ (Cereja \& Magalhães, 2004, Faraco \& Moura, 2004) nos permite sintetizar, com pouquíssimas diferenças ${ }^{2}$, os seguintes dados sobre o assunto:

1. Em geral não se fala de estruturas passivas, e sim de voz passiva, definindo-a como a forma verbal que indica que a pessoa/sujeito recebe a ação verbal, sendo, portanto, seu paciente. Dessa maneira - segundo esses manuais - , a voz passiva surge em oposição à voz ativa, na qual a pessoa/sujeito pratica a ação verbal, convertendo-se em seu agente.

2. A voz passiva é classificada em dois tipos: passiva analítica (ou passiva perifrástica, formada geralmente com verbo auxiliar "ser" + particípio) e

\footnotetext{
${ }^{1}$ A referência completa dessas publicações está na Bibliografia (seção "Livros didáticos e paradidáticos consultados”).

${ }^{2}$ A saber: Bechara (1976:105) diferencia a voz passiva (forma especial em que se apresenta o verbo para indicar que a pessoa recebe a ação: Ele foi visitado pelos amigos/ Alugam-se bicicletas) da passividade (fato de a pessoa receber a ação verbal, o qual também se pode expressar por verbos na forma ativa, porém de sentido passivo: Os criminosos recebem o merecido castigo). Luft (1996:177-8) cita construções passivas com outros auxiliares além do verbo "ser": Ele está/ anda/ vive cercado de amigos; Ele ficou rodeado de amigos; A mala ia/ vinha carregada pelo homem. André (1997:168) também dá exemplos dessas construções e menciona a passiva de infinitivo: O imperador deu a mão a beijar; Que osso duro de roer!
} 
passiva pronominal (com o pronome oblíquo "se", que no caso recebe a denominação de pronome apassivador). Além dessa diferença formal, os comentários adicionais feitos sobre tais variedades são que: a) a passiva analítica pode apresentar o verbo em qualquer pessoa, ao passo que a pronominal só se constrói nas $3^{\text {as }}$ pessoas; b) enquanto na passiva analítica é freqüente a presença do agente, na passiva pronominal ele não aparece.

3. A voz passiva se constrói com verbos transitivos diretos.

Nesse tipo de abordagem fica patente que a ênfase que se dá ao tema recai sobre o aspecto formal, conforme bem o mostram os itens 2 e 3 acima. De fato, os critérios sintáticos presentes nesses itens são importantes para que se reconheça uma estrutura passiva. Mas serão suficientes para a compreensão do fenômeno? A definição dessas construções, no item 1, diznos que não: nela estão os conceitos de agente e paciente, que não pertencem à sintaxe propriamente dita, mas à semântica (semântica de casos, os papéis temáticos, mesmo que não se chegue a falar propriamente dessa perspectiva teórico metodológica). Também a referência à passividade como o "receber a ação verbal" remete mais ao significado que à forma. Daí a necessidade de tratar o tema a partir de ambas as perspectivas, a sintática e a semântica, que para vários autores, entre eles Cançado $^{3}$, guardam uma relação estreita e importante. Outra falha das abordagens da voz passiva encontradas nas publicações didáticas é o "colar" uma forma a um significado: pouco se levam em conta as possibilidades de expressar conteúdos passivos por meio de construções/ padrões lingüísticos distintos ao que se descreve no item 2. Em suma, as abordagens da questão são bem pouco amparadas pelas pesquisas lingüísticas teoricamente fundamentadas e parecem repetir-se, em muitos casos, sem maiores avanços na interpretação.

\footnotetext{
${ }^{3}$ Em Cançado (2000), ao discorrer sobre a teoria generalizada dos papéis temáticos que desenvolveu com Franchi, afirma a autora: “(...) temos evidências de que existem certas propriedades semânticas que são relevantes para a estruturação sintática das línguas, e insistir em um modelo onde o conteúdo semântico dos papéis temáticos é levado em consideração não é uma simples questão de gosto. Isso se deve à existência de alguns dados empíricos que corroboram a necessidade para uma teoria gramatical de se distinguir semanticamente esses papéis. Ou seja, se existem questões de natureza semântica, mais especificamente, questões envolvendo o conteúdo semântico dos papéis temáticos que restringem e/ou ordenam a estruturação sintática das orações, estas devem fazer parte de uma teoria gramatical.”
} 
Ainda sobre o enfoque formal, é certo que este se reproduzia (e se reproduz) também na escola: aprender as estruturas passivas transformava-se em aprender a voz passiva tal como figurava nos livros didáticos e em boa parte das gramáticas (sobretudo aquelas de cunho prescritivo). Bastava dominar as poucas regras apresentadas e exercitá-las por meio de tarefas repetitivas, que consistiam em converter frases ativas em passivas e viceversa. Destacava-se, sobretudo, o processo, a transformação e os artifícios que se usavam para passar de uma forma a outra. Na ocasião, duas questões já me incomodavam: 1) Seriam essas formas equivalentes em sentido?; 2) Que implicações haveria em optar-se por uma ou outra construção?

Para concluir meu raciocínio, ressalto que essa tarefa mecânica de transformar ativas em passivas (e o contrário) acabava por adquirir o aspecto de um jogo ou brincadeira, ao fim da qual muitos estudantes se perguntavam que finalidade poderia ter. É claro, tal aspecto lúdico não seria problemático caso se passasse desse momento a uma reflexão sobre as formas da língua, como funcionam e que sentidos e valores cada uma delas comporta e assume em cada circunstância. No caso específico das construções passivas, pensar, por exemplo, nos efeitos obtidos ao enfatizar-se um sujeito paciente ou omitirse um agente.

Em 1998, durante o meu curso de graduação, estudei novamente as passivas na língua espanhola e de imediato as questões que mencionei voltaram à tona. Mas foi somente a partir do segundo semestre de 2002, como monitor do Español en el Campus ${ }^{4}$, que comecei a observar como apareciam as passivas nas produções escritas (em Espanhol) dos meus alunos. O que mais me chamou a atenção nessas redações foi a alta incidência das passivas perifrásticas e o baixo percentual de passivas pronominais, já apontado por González (1994). Os trabalhos que eu havia lido sobre as passivas no Espanhol (em especial, Barrenechea \& Manacorda de Rosetti, 1979) apontavam exatamente o contrário: que nessa língua havia predileção pela passiva com pronome. Igualmente, os estudos sobre as passivas no Português

\footnotetext{
${ }^{4}$ Doravante EEC. Trata-se de um curso extracurricular de E/LE oferecido pela Área de Língua Espanhola e Literaturas Espanhola e Hispano-Americana — DLM e mantido pelo Serviço de Cultura e Extensão da USP/FFLCH.
} 
Brasileiro (doravante PB) - por exemplo, Duarte (1990) - mostravam a preferência dos falantes nativos pela passiva perifrástica. Portanto, pensando na ocorrência predominante das passivas perifrásticas na produção escrita em Espanhol dos aprendizes brasileiros, identifiquei no fenômeno o que parecia ser uma interferência da língua materna. Então, às questões anteriores somaram-se outras: 1) Que fatores explicariam essa possível interferência? 2) As passivas no Espanhol e no PB tinham somente assimetrias ${ }^{5}$, ou também apresentavam tendências comuns? 3) A preferência dessas línguas por uma forma de passiva podia ser tomada de maneira absoluta, ou havia outros elementos a considerar (funções pragmáticas, gêneros textuais, etc.)?

No meu entender, as respostas a essas perguntas dependiam de um estudo que partisse da investigação detalhada do funcionamento das passivas no Espanhol e no PB, para, em seguida, abordar os fenômenos relacionados às construções passivas na produção dos brasileiros em língua espanhola. É o que busco fazer neste trabalho.

Na primeira parte do capítulo I, sintetizo e comento alguns dos estudos teóricos dedicados às construções passivas, tanto no Espanhol quanto no PB. $\mathrm{Na}$ segunda parte do capítulo, utilizando parte desses estudos, faço uma análise contrastiva das passivas nas duas línguas, na qual se discutem as construções predominantes em cada uma delas, o estatuto teórico e as particularidades dos papéis temáticos envolvidos (Agente e Paciente), as funções pragmáticas (Tema e Rema) relevantes, assim como os usos das estruturas passivas.

No capítulo II, descrevo os corpora analisados na pesquisa, assim como as ferramentas empregadas na obtenção dos resultados.

No capítulo III apresento esses resultados e os discuto no capítulo seguinte, lançando hipóteses sobre os fenômenos que influem na produção de construções passivas, em Espanhol, por aprendizes brasileiros de E/LE. Finalmente, como apêndice deste trabalho, incluo um CD ROM com os anexos e os corpora utilizados.

${ }^{5}$ A noção de assimetria foi utilizada em González (1994), ao descrever o preenchimento vs. não preenchimento das posições argumentais de sujeito e objeto no Português Brasileiro e no Espanhol. 
Mais que analisar como aparecem as estruturas passivas nas produções em E/LE de aprendizes brasileiros, ou fazer um levantamento da freqüência de uso de cada uma delas, meu propósito é investigar que fenômenos lingüísticos levam esses aprendizes a escolher, dentre as possibilidades que a língua espanhola lhes oferece, determinadas construções passivas em detrimento de outras.

Portanto, o objetivo do meu trabalho é responder às seguintes questões:

- Que assimetrias e tendências comuns apresentam o PB e o Espanhol no que diz respeito às estruturas passivas?

- A preferência dessas línguas por um tipo de construção passiva pode ser tomada de maneira absoluta, ou haveria outros elementos a considerar (funções pragmáticas, gêneros textuais, etc.)?

- Há interferência da língua materna na produção em E/LE de aprendizes brasileiros?

- Se houver, que fatores possivelmente explicariam essa interferência? 
CAPÍTULO I

As passivas no Espanhol e no PB

\section{I.1. Considerações preliminares}

Esta investigação tem como ponto de partida o estudo detalhado do funcionamento do Espanhol e do PB com respeito às passivas. No meu entender, esse aprofundamento - tanto na língua materna do aprendiz quanto na língua estrangeira que ora ele estuda - é essencial para compreender o processo de aquisição/aprendizagem de uma língua e intervir nele. É preciso reconhecer, entretanto, que apesar de a língua materna influir de modo inegável nesse processo, conforme vêm demonstrando diversos estudos nesse campo, inclusive de bases epistemológicas diferentes ${ }^{6}$, dele também participam fatores de natureza social e afetiva - os quais, por razões de brevidade, estão fora do escopo deste estudo.

Como fundamento do meu trabalho, também está a necessidade de acrescentar novas reflexões, por mínimas que sejam, ao ensino e aprendizagem de línguas. Isso por reconhecer que, apesar das constantes contribuições dos estudos lingüísticos (em especial a lingüística do texto), as aulas de língua materna na escola ainda estão condicionadas a um enfoque majoritariamente normativo (com poucas exceções) - o que inevitavelmente tem desdobramentos no ensino e aprendizagem de uma língua estrangeira

\footnotetext{
${ }^{6} \mathrm{O}$ papel da língua materna (LM) na aquisição/aprendizagem das línguas segundas foi objeto de muita controvérsia anteriormente, porém hoje é praticamente unânime o reconhecimento, por parte dos estudiosos, de que a LM desempenha um papel importante e é um fator relevante - embora não seja o único - nesse complexo processo; tanto os pesquisadores que trabalham numa linha gerativista — que focalizam cognitivamente a aquisição da gramática das línguas segundas — , quanto os que trabalham numa linha mais discursiva — embasada na psicanálise —, reconhecem, por distintas razões, que a LM é crucial no processo. Entretanto, tal reconhecimento não ocorre no sentido em que a análise contrastiva via o fenômeno: no primeiro dos modelos, a LM intermedeia o processo, quando não, para alguns, substitui a Gramática Universal (GU); no segundo modelo, fala-se sobre o papel da LM na constituição simbólica do aprendiz. Ainda no segundo modelo, fala-se da importância da LM nos processos de inscrição do sujeito nas discursividades da língua estrangeira que está aprendendo.
} 
$(\mathrm{L} 2)^{7}$. Basta citar o que pensam e fazem os professores de L2 quando a questão que se lhes propõe é ter que tratar em classe um item gramatical: mesmo que o docente demonstre considerável grau de reflexão sobre seu objeto (a língua) a partir de outras perspectivas que não o padrão, na hora $\mathrm{H}$ o que normalmente aflora na sua prática é o peso da tradição, ou seja, o aprender/ser ensinado que converte a gramática em algo rançoso, arbitrário, aborrecido, estrito e limitador. Esse modo de proceder corresponde a um imaginário de língua, de gramática, de ensino, que se reproduz na contramão das ditas e apregoadas inovações - o que por vezes as converte em pura maquiagem nos materiais didáticos e na fala do docente ${ }^{8}$. Quanto aos aprendizes, habituados à pouca reflexão sobre determinados usos lingüísticos, acabam incorporando-os indevidamente, não raro por meio do transporte de estruturas da língua materna para a língua estrangeira que estão aprendendo. É voz comum a afirmação de que esse processo será mais freqüente se a L2 for o Espanhol, uma vez que a sua semelhança com o Português faz com que o aprendiz alimente a ilusão de uma comunicação sempre transparente e inequívoca com os hispanofalantes. Mas é preciso deixar claro que não se trata aqui de uma hipótese contrastiva de primeira hora: estaríamos equivocados se pensássemos assim, já que a transferência não se dá de forma simples, termo a termo. Felizmente, essa imagem do Espanhol e do PB como línguas simétricas - ou seja, cujos elementos, estruturas e níveis têm

\footnotetext{
${ }^{7}$ Adoto a forma abreviada L2 para designar a língua estrangeira aprendida em situação formal, fora de um contexto natural. Por oposição, passo a designar a língua materna através da forma L1. Isso não quer dizer que não estabeleça uma clara diferença entre o que se pode entender por segunda língua e língua estrangeira, posto que as condições de aquisição/aprendizagem da primeira é, em geral, muito diferente das condições em que se dá o processo de aquisição/aprendizagem da segunda. Por outro lado, também tenho clara a diferença entre os processos de aquisição de segunda língua, em situações naturais e de imersão, daqueles de aprendizado formal, fora de contextos naturais em que a língua aprendida é a língua de comunicação, situação não contemplada neste trabalho.

${ }^{8}$ Para melhor ilustrar minha afirmação, transcrevo um fragmento da contracapa de Cereja \& Magalhães (2004), obra destinada ao ensino fundamental: "Rompendo com a tradicional abordagem gramatical, que se limitava ao horizonte da frase, o estudo volta-se essencialmente para o texto e o discurso. Não o texto como pretexto para a mera classificação gramatical, mas como objeto e objetivo maior dos estudos lingüísticos; o texto em sua dimensão discursiva, isto é, inserido numa situação concreta de enunciação, servindo a determinado fim, mediando as interações entre os interlocutores.” Entretanto, o que esses autores dizem acerca das passivas nada acrescenta à abordagem tradicional: não se levam em conta outros tipos de construções passivas, nem os papéis temáticos em jogo (Agente, Paciente) e muito menos as funções pragmáticas (Tópico, Foco, Tema, Rema), tão caras ao discurso.
} 
correspondentes exatos de uma língua para outra - vem sendo suplantada por meio de inúmeros trabalhos acadêmicos, como o de González (1994).

$\mathrm{E}$ agora passemos à outra face da moeda: o modo como o tema em questão - as estruturas passivas - aparece nos livros didáticos, paradidáticos e manuais de E/LE. Eu diria que, mais que aparecer, o tema é sistematicamente eludido em grande parte dessas publicações ${ }^{9}$, algumas das quais são das mais adotadas em cursos de diversas naturezas: faz-se uma breve descrição do fenômeno (à semelhança do Português, como voz passiva), classifica-se a estrutura em passiva perifrástica (frase verbal pasiva ou pasiva con ser, formada com o auxiliar ser + particípio) e passiva pronominal (pasiva refleja ou pasiva con se, com o pronome oblíquo se + verbo na $3^{\text {a }}$ pessoa), salienta-se o pouco uso da passiva perifrástica em Espanhol e o conseqüente predomínio da passiva pronominal e, finalmente, vêm os exercícios esquemáticos de conversão de uma forma na outra, conforme já comentei. Existe, é claro, a preocupação de diferenciar a passiva pronominal (refleja) das estruturas impessoais, porém isso é feito em geral unicamente com base na forma $^{10}$. O critério semântico (fundamentado nos papéis temáticos Agente e Paciente), de suma importância na questão, passa nitidamente a um segundo plano, assim como o caráter passivo intrínseco às formas verbais (como em: la sobrina padecía reúma ${ }^{11}$ ). Não se problematiza o fato de existirem outros possíveis papéis temáticos além dos de Agente e Paciente ${ }^{12}$ (na frase la policía es temida por los manifestantes, o constituinte los manifestantes não é um

\footnotetext{
${ }^{9}$ Livros consultados: Planet@, de Cerrolaza et alii: Libro del alumno, vol. 1 (1998), 2 (1999), 3 (2000) e 4 (2000); Libro de referencia gramatical, vol. 1 (1998), 2 (1999), 3 (2000) e 4 (2000); Uso de la gramática española, de Castro, vol. 1 (1996), 2 (1997) e 3 (1997); Claves del Español, de Domínguez e Bazo (1994) e Gramática básica del español, de Sánchez e Sarmiento (2001) (para a referência completa dessas publicações, ver Bibliografia, seção "Livros didáticos e paradidáticos consultados”). É necessário dizer que selecionei apenas alguns manuais dentre os vários disponíveis no mercado brasileiro, e o critério adotado foi a boa aceitação desses materiais nas nossas escolas.

${ }^{10}$ Ressalto que o tratamento do tema varia muito entre um livro e outro. Sánchez e Sarmiento (2001) dedicam dois comentários brevíssimos sobre as passivas, enquanto Domínguez e Bazo (1994) abordam a questão de forma mais distendida e com mais exemplos — é a única obra, dentre as referidas neste item, que fala das passivas em termos de usos e funções.

${ }^{11}$ Alarcos Llorach (1970: 125).

${ }^{12}$ Essa nomenclatura acaba sendo a adotada em muitos estudos devido ao seu uso tradicional — é o "peso da tradição", já mencionado neste item. Entretanto, há lingüistas que propõem classificações mais abrangentes para os papéis temáticos: Cançado (2003), por exemplo, define os papéis temáticos não como noções (Agente, Paciente, Experienciador, Instrumento, Força, etc.) e sim como uma composição de propriedades (Desencadeador, Afetado, Estado e Controle) atribuídas a um dado argumento a partir de acarretamentos estabelecidos por toda a proposição em que esse argumento se encontra.
} 
Agente - como seria esperado na "fórmula" da passiva sintática - e sim um Experienciador), e tampouco a impossibilidade de se construir a passiva com verbos transitivos diretos ${ }^{13}$ em determinadas situações (caso de: los árboles tienen hojas, *hojas son tenidas por los árboles). Em suma, nos materiais didáticos de que dispomos para ensinar/aprender Espanhol, pouco se fala dos usos das construções passivas e dos diferentes sentidos que podem comportar ditas formas.

Levando em consideração as razões apresentadas, acredito que um estudo acurado de como se comportam as construções passivas no PB e no Espanhol, além de elucidar questões referentes ao tema, poderia fornecer subsídios para seu tratamento - tanto nos materiais didáticos quanto no ensino de E/LE - de maneira menos simplista e mais estimuladora da reflexão. É o que faço a seguir, apresentando como hipóteses iniciais:

- As passivas tanto no PB quanto no Espanhol são estruturas marcadas ${ }^{14}$, ou seja, os lusofalantes e os hispanofalantes preferem as construções ativas.

- As passivas no PB e no Espanhol apresentam tanto tendências comuns, quanto assimetrias.

- As passivas tanto no PB quanto no Espanhol se relacionam a determinados fenômenos sintáticos (transitividade), semânticos (papéis temáticos) e discursivos (funções pragmáticas: Foco, Tópico, Tema, Rema).

- A incidência/freqüência de construções passivas na produção em Espanhol dos estudantes brasileiros de E/LE reflete fenômenos existentes na língua materna desses aprendizes.

\footnotetext{
${ }^{13}$ É preciso esclarecer que, em Espanhol, com relação à transitividade, os verbos são classificados apenas em transitivos e intransitivos, conforme a admissão ou não de um objeto direto. Nas palavras de Alarcos Llorach (1994: 280-81): "La posibilidad o imposibilidad de que el verbo admita objeto directo ha sido el criterio de clasificación de los verbos en transitivos e intransitivos. Cuando la actividad denotada por la raíz verbal requiere la especificación aportada por el sustantivo que funciona como objeto directo, se considera el verbo transitivo; en caso contrario, el verbo es intransitivo."

${ }^{14}$ Conforme Crystal (1988: 168), de modo geral, a noção de marcado refere-se à presença ou ausência de um determinado traço lingüístico. É o caso, por exemplo, do traço formal marcando o plural dos substantivos e adjetivos do Português: o plural, portanto, é marcado , enquanto que o singular é nãomarcado. Outras interpretações da mesma noção são encontradas na literatura do assunto, onde o conceito de "presença" versus "ausência" , todavia, não se aplica muito bem. Uma delas focaliza a freqüência da ocorrência e define marcado como menos freqüente; é essa interpretação que adoto neste estudo.
} 


\section{I.2. Acerca das passivas no Espanhol}

A título introdutório, farei aqui um breve apanhado de alguns estudos realizados por gramáticos e lingüistas acerca das passivas - tanto no PB como no Espanhol - , com o qual pretendo representar (embora minimamente) a diversidade de perspectivas adotadas na análise do assunto.

No Espanhol, a controvérsia começa na própria caracterização formal das passivas:

1. Nebrija (apud Lenz, 1935: 112, citado por Fanjul, 1999: 148), afirma que "(...) el latín tiene tres voces: activa, verbo impersonal, pasiva; el castellano no tiene sino solo la activa", ou seja, exclui da língua espanhola a voz passiva.

2. Segundo Bello (1984: 151), “(...) las construcciones en que el verbo tiene un complemento acusativo, se llaman activas. Si este complemento pasa a sujeto, y el participio que se deriva del mismo verbo invierte su significado y concierta con el sujeto, la construcción es pasiva."

3. A partir de um enfoque lógico e psicológico, Gili Gaya (1978: 121-22) afirma que a relação lógica entre o sujeito e seu complemento não se modifica ao mudar-se a forma gramatical (oração ativa ou passiva); o que se modifica é o ponto de vista do falante, ao escolher como sujeito o desencadeador ou o afetado pela ação.

4. Para Alarcos Llorach (1970: 90), a voz passiva é um "accidente" no sistema verbal do Espanhol. Reconhece, porém, que o Espanhol pode expressar conteúdos passivos, embora estes careçam de forma lingüística diferenciada na língua (ibid.: 94). Mais adiante (1970: 127), afirma que o valor ativo ou passivo que se identifica numa expressão não depende de particulares relações formais e gramaticais dentro da oração, e sim de relações léxicas. "Como estructuras oracionales nos encontramos siempre una sola: la de tipo atributivo" (1970: 132).

5. Lázaro Carreter (1981: 61-72), embora elogie a análise procedida por Alarcos Llorach, discorda deste quanto à indistinção gramatical entre 
atribuição e passividade. Segundo Lázaro Carreter, essa indistinção vai de encontro à consciência idiomática do falante-ouvinte, para o qual essas entidades se diferenciam nitidamente. Afirma o lingüista: "Una gramática que no los trate como capítulos separados, tiene que resultarle sospechosa de error, y dudo de que le resulte convincente la explicación de que el análisis 'tiene que' prescindir del significado. En todo conflicto entre formulación gramatical y sentimiento espontáneo de la lengua, es éste el que, por principio, merece mayor confianza."

6. Em análise formal detalhada, Barrenechea \& Manacorda de Rosetti (1969) concluem que "(...) la voz pasiva (en la construcción ser + participio) es, en el sistema español, una categoría gramatical por sus características funcionales". Mais adiante, e segundo critérios semelhantes, demonstram (ibid.: 93) a existência da "pasiva con se". No mesmo trabalho, as autoras criticam a definição da passiva por alguns gramáticos (inclusive a RAE) a partir de um "(...) criterio psicológico, atendiendo a las relaciones entre el actor, el proceso y el objeto" (ibid.: 72).

Lorenzo (1980: 17-20), por sua vez, dá pouca importância à caracterização formal da voz passiva e prefere ressaltar o "(...) rico y matizado inventario de soluciones" (ibid.: 19) de que dispõe o Espanhol para construir expressões de sentido passivo quando se quer designar uma ação sem agente explícito. A seguir transcrevemos as possibilidades que o autor cita (ibid.: 20):

- con verbo auxiliar:

(1) El niño fue abandonado. (alguém o abandonou)

(2) El niño quedó abandonado.

(3) El niño estaba abandonado. (había sido abandonado)

(4) El niño se vio abandonado./ El niño se sintió abandonado. (consciência do abandono; segundo o autor, isso excluiria uma criança pequena)

(5) Los libros vienen/van acompañados de un apéndice.; La venta viene/ va condicionada al pago inmediato. 
(6) Cinco hectáreas fueron inundadas. (implica agente ou intenção); Cinco hectáreas resultaron/quedaron inundadas.

(7) Cinco viajeros resultaron/salieron malparados.

- impersonal activa:

(8) Al niño lo abandonaron./ Abandonaron al niño.

- pasiva refleja:

(9) Se inundaron cinco hectáreas./ Se acompañan los libros de un apéndice.

- pasiva inconclusa:

(10) Van rescatadas cinco víctimas.

- nominal:

(11) La conquista de Roma. (Roma fue conquistada)

As construções com sentido passivo como (4) também são citadas por Fernández Ramírez (1986: $\S 78$ ). Os verbos que constituem essas perífrases (verse, sentirse, hallarse, encontrarse, etc.) são chamados pelo lingüista de verbos de percepción en forma reflexiva. A seguir, dou exemplos dessas construções, recolhidos de Mendikoetxea (1999:1625):

(12) Los pisos más bajos se vieron alcanzados por las llamas.

(13) Los vecinos se sintieron engañados por las autoridades.

(14) Toda la comarca se halla afectada por la sequía.

(15) Los edificios se encuentran dañados por la sacudida.

Para Mendikoetxea (ibid.), as perífrases de particípio com quedar/quedarse e resultar (ver (6) e (7)) enfatizam a condição ou estado de algo como resultado de uma ação ${ }^{15}$. Ainda segundo a autora, as construções com permanecer destacam não um resultado, porém uma condição ou estado vigente:

(16) Permanecen cerrados los colégios ${ }^{16}$.

\footnotetext{
${ }^{15}$ Nesse sentido, Mendikoetxea acrescenta que o uso de quedar tem um significado equivalente a estar em expressões do tipo queda cerrado, queda dicho, etc.

${ }^{16}$ Este exemplo é da autora, assim como os subseqüentes (até o de número 28).
} 
Mendikoetxea (ibid.) também considera com significado passivo as construções de particípio absoluto nas quais o verbo é transitivo ${ }^{17}$ :

(17) Leída el acta, comenzó la reunión.

Concluindo seu repertório, Mendikoetxea (ibid.) cita as construções de infinitivo com sentido passivo, subdividindo-as em três variedades:

a) complemento de um verbo causativo com se (dejarse, hacerse), que inclusive podem ter agente explícito:

(18) Pedro se dejó engañar por su amigo.

(19) El orador se hizo entender por todo el mundo.

b) modificador de adjetivo $(+d e)$, nas quais o agente não figura explicitamente e é interpretado de forma genérica:

(20) El problema es fácil de resolver.

(21) Su comportamiento es digno de notar.

c) modificador de nome $(+a)$, nas quais se permite a expressão do agente:

(22) Una idea a considerar (por los compromisarios).

(23) Un proyecto a realizar (por un grupo de arquitectos).

Apesar das discordâncias quanto à existência ou não de uma forma própria para as passivas em Espanhol, há convergência no que diz respeito à freqüência de uso de tais estruturas: é consenso, entre os gramáticos e lingüistas que consultei, que a língua espanhola tem uma marcada preferência pela passiva pronominal — fato corroborado por diversos estudos quantitativos, como o realizado por Barrenechea \& M. de Rosetti (1977) para a voz passiva no Espanhol falado em Buenos Aires ${ }^{18}$ — , e que o uso da passiva perifrástica

\footnotetext{
${ }^{17}$ Há casos, entretanto, nos quais seriam possíveis duas interpretações, como no exemplo da autora: Hundido el barco, el capitán abandonó el lugar. Para esse enunciado, poderíamos ter uma interpretação passiva (Una vez fue hundido el barco...) ou inacusativa (Una vez se hundió el barco [por sí solo]...).

${ }^{18}$ Considerando que já se passaram quase três décadas desde a publicação desse estudo, é possível que uma reavaliação do fenômeno aponte mudanças na freqüência de uso das passivas no Espanhol portenho. Igualmente, seria necessário um estudo que tivesse em conta o aparecimento dessas construções em distintos gêneros textuais, entre outras coisas.
} 
relaciona-se a determinados efeitos de sentido e gêneros específicos. Kovacci (1977: 147), permanecendo no âmbito da sintaxe, atribui à passiva perifrástica um valor expressivo que advém do interesse em destacar-se o sujeito paciente. Domínguez \& Basso (1994: 131) vão além do afirmado por Kovacci, especificando outros usos e funções das passivas:

1. Aunque el español tiene marcada preferencia por la construcción activa, se utiliza la pasiva en los siguientes casos: a) cuando queremos destacar el sujeto paciente, b) cuando el sujeto agente es desconocido, o bien c) cuando éste ya es conocido y no hace falta identificarlo.

2. La pasiva con ser se utiliza preferentemente en el lenguaje escrito, sobre todo en el periodístico, y en relación con tiempos verbales pasados. El sujeto agente suele mencionarse en estos casos (Ej.: Varios sospechosos han sido detenidos por la policía; La ley de presupuestos fue aprobada por el Parlamento).

Em estudos mais recentes, percebe-se a preocupação de estudar as passivas não apenas do ponto de vista da sintaxe. Mendikoetxea (1999:1621), por exemplo, considera que a possibilidade de formar construções passivas perifrásticas relaciona-se mais com o léxico que com a transitividade:

En realidad el hecho de que los verbos que aparecen en oraciones pasivas perifrásticas sean transitivos se sigue de su aspecto léxico: son verbos que expresan eventos o transiciones, es decir acciones que van de un sujeto nocional a un objeto externo a la acción del verbo. Por ejemplo, un verbo como construir en Los albañiles construyeron esta casa expresa una acción del sujeto los albañiles cuya culminación lógica es la casa costruida. El verbo construir expresa un evento (realización) que es perfectivo y sintácticamente transitivo como consecuencia de su significado léxico.

Como reforço à sua argumentação, Mendikoetxea (ibid.) cita exemplos de construções transitivas cujos verbos possuem objetos $\operatorname{cognados}^{19} \mathrm{e}$, portanto, não admitiriam a passiva perifrástica:

(24) Llorar el llanto de um niño. / *El llanto de un niño es Ilorado.

(25) Cantar canciones. / ${ }^{*}$ Canciones son cantadas ${ }^{20}$.

\footnotetext{
${ }^{19}$ Segundo a autora, esse tipo de complemento é simplesmente uma continuação semântica do verbo. Campos (1999) também cita as denominações objetos internos o objetos tautológicos. A RAE (1973: § 3.5.1c) dá exemplos de complementos diretos extraídos do próprio significado do verbo, identificando nestes um valor estilístico: Morir una muerte gloriosa; Dormir un sueño tranquilo; Vivir una vida miserable.

${ }^{20}$ A autora faz uma ressalva com respeito a cantar: nos casos em que o objeto interno aparece determinado, não há restrições à passiva: Los invitados cantaron la canción con mucha emoción. / La canción fue cantada (por los invitados) con mucha emoción.
} 
Mendikoetxea (ibid.) também destaca a proximidade entre as construções passivas e as inacusativas, de um ponto de vista discursivo-funcional:

(26) Juan cerró las puertas. (transitiva)

(27) Las puertas se cerraron. (inacusativa)

(28) Las puertas han sido cerradas. (passiva)

Em (27) e $(28)^{21}$, o objeto da construção transitiva é o ponto de partida do resto do enunciado, a partir do qual se distribui a informação: é o sujeito (função sintática), o paciente (função semântica ou papel temático) e o tema (função pragmática ou discursiva). O sujeito/agente/tema da construção transitiva passa a uma posição secundária ou é suprimido do enunciado ${ }^{22}$.

Fanjul (1999: 147), em seu trabalho sobre a versão PB-Espanhol, fala dos efeitos de sentido que tem a passiva perifrástica de uma perspectiva discursiva, vinculando-a a determinados gêneros:

La lengua española muestra una marcada preferencia por la pasiva con "se". El uso de la pasiva perifrástica, que en portugués es tan habitual, en español se reduce a contextos muy específicos: titulares de diarios, poesía y otros, y suele tener un matiz dramático que analizaremos más adelante.

Mais adiante (ibid.: 150), amplia suas afirmações e dá exemplos:

Violencia, tragedia, ruptura de una orden, suelen ser concomitantes con el uso de dicha estructura en español para referirse a seres humanos. (...) No casualmente, la pasiva perifrástica, a veces con elisión del verbo auxiliar, es una de las formas preferidas en los titulares y copetes de la prensa sensacionalista: "Familia masacrada por ladrones", "El cadáver de la viuda fue encontrado en el incinerador" y otros por el estilo, resuenan fácilmente en la memoria discursiva del hispanohablante y lo predisponen como receptor para determinados géneros.

Nos trabalhos mencionados a seguir ${ }^{23}$, a análise das passivas está focada em seus aspectos semânticos e pragmáticos. É o caso de Miñones \& Sánchez (1999) que, considerando a passiva perifrástica como uma estrutura com

\footnotetext{
${ }^{21}$ Mendikoetxea (ibid.), embora enfatize a proximidade das duas construções quanto à função que desempenham, chama a atenção para as diferenças de significado entre ambas. O exemplo (27), em sua interpretação inacusativa, expressa na língua uma ação que se produz de forma espontânea sem a intervenção de um agente ou causa externa, "independientemente de que en el mundo real sea posible atribuir uma causa concreta a la eventualidad que expresa la oración.” Por esse motivo, enunciados como (27) são compatíveis com adjuntos do tipo [él/ella] solo/a/os/as, por sí mismo/a/os/as, por sí solo/a/os/as (Las puertas se cerraron por sí solas) e incompatíveis com adjuntos agentivos (*Las puertas se cerraron por el director).

${ }^{22}$ Este processo é denominado detematização do agente. Será retomado oportunamente, quando forem tratadas as funções das passivas.

${ }^{23}$ Todos eles referentes ao Espanhol escrito. Faço um comentário breve destes estudos na presente seção, uma vez que serão retomados mais detalhadamente em I.4.
} 
significado e contextos ${ }^{24}$ de aparição específicos — não compartilhados com a ativa -, realizam uma descrição sintática dessa passiva que permite caracterizar seus referidos contextos. A hipótese das autoras é de que a aparição das passivas perifrásticas se relaciona a determinadas características dos sintagmas nominais (SN) ${ }^{25}$ envolvidos no processo verbal: Paciente (com alto grau de afetação, alta referencialidade à esquerda da estrutura e dotado de traço [-humano]) e Agente (com persistência à direita, abrindo cadeia tópica e possuidor dos traços [+humano] e [+vontade]). Miñones (2000) estuda as passivas perifrásticas sem Agente explícito, a partir dos contextos preferenciais nos quais este é elidido, e também com base em aspectos relacionados à tematização do Paciente. Barbeito \& Miñones (2002) dedicam-se às passivas pronominais (reflejas ou con se), interessadas sobretudo nas características do Paciente nessas construções.

Focalizando os aspectos discursivos relacionados ao se, Serrani (1984) estuda o funcionamento desse pronome em enunciados impessoais. Serrani, nos quatro textos que analisa, preocupa-se com os enunciados "nos quais o agente não está exposto ao destinatário, porém oculto — ou, ao menos, parcialmente oculto - pela generalização que o se 'impessoal' possibilita a nível explícito." Para maior clareza, incluo os textos mencionados e um comentário breve das análises da autora sobre cada um deles:

1) Texto A: fragmento de carta Buenos Aires - Campinas (outubro/1982), enviada à autora por sua mãe. O referente geral desse fragmento é a mudança de colégio do irmão da destinatária:

Terminó la gran pesadilla: saqué a Marce del Liceo. Cuando me aseguré del banco en el otro colegio, busqué a papá. Lo convencí. Fuimos los dos a solicitar el pase. Papi, serio durante todo el tiempo. Él piensa que era bueno para el nene. No se le puede reprochar por el momento. Papi no se puede poner nervioso. [ibid.: 149-150; grifo da autora]

No fragmento em destaque, segundo Serrani (ibid.:151), o se possibilita à locutora uma generalização apoiada no bom senso, cuja finalidade é evitar qualquer reprimenda ou cobrança por parte da destinatária, sob pena de agravar o estado de saúde do seu pai.

\footnotetext{
${ }^{24}$ Termo usado pelas autoras.

${ }^{25}$ No original, FN: frase nominal.
} 
2) Texto B: fragmento de uma canção do autor catalão Joan Manuel Serrat, na qual se reproduzem expressões comuns do discurso cotidiano na relação entre pais e filhos:

Esos locos bajitos que se incorporan/ con los ojos abiertos de par en par, / sin respeto al horario ni a las costumbres,/ y a los que "por su bien" hay que domesticar, / "Niño, deja ya de joder con la pelota."/ (...)/ "Niño, que eso no se dice", / "que eso no se hace", / "que eso no se toca". [ibid.: 152; grifos da autora]

Nas expressões sublinhadas, de acordo com a autora (ibid.:153), o locutor evita coibir seu interlocutor de maneira direta, como autor explícito da proibição: ele o faz por meio do uso de construções se-verbo, as quais exprimem uma generalização de costumes; e por serem esses costumes endossados pela sociedade, torna-se mais difícil para o interlocutor perguntar o porquê, o motivo das proibições. Portanto, de uma perspectiva argumentativa, Serrani (ibid.) considera que as construções eso no se dice, eso no se hace e eso no se toca correspondem, em realidade, a: no digas eso, no hagas eso e no toques eso.

3) Texto C: diálogo entre uma freguesa $(F)$ e uma vendedora $(V)$, ocorrido numa loja de roupas de Buenos Aires (setembro/1982):

F: —Buenos días. Busco un pantalón de paño azul, finito, de corte recto, sencillo...

$V:-$ Ahora se usan éstos.

F: - Sí, pero...

$V:$ - Se llaman baggies.

F: - Sí, ya sé, gracias. Pero yo quería de los más angostos.

V: - (Sem olhar para a freguesa e fixando a vista nas calças baggies) No, no hay. Ahora se usan así. [ibid.: 153; grifos da autora]

Neste caso, o uso das construções se-verbo propiciam à vendedora uma generalização fundamentada na moda. Para Serrani (ibid.: 154), ao argumentar explícita e categoricamente com base na uniformidade do vestir (ahora se usan estos; ahora se usan así), a vendedora não se propõe a uma real interlocução; ao contrário, constitui-se como agente exclusivo, eliminando qualquer possibilidade de resposta por parte da freguesa.

4) Texto D: fragmento de carta, cujas condições de produção coincidem com as de $A$ :

Espero no tomes a mal lo que voy a escribir, pero que no hayas hecho (X) por no haber tenido dinero me preocupó mucho. Que salgas, que disfrutes, te compres cosas y viajes está muy bien, pero que no tengas nada ahorrado está muy mal. La verdad 
que me dolió mucho. Creo que tenías otra escuela en casa. Hasta en los momentos más críticos siempre pudimos responder porque si se gana 20 , se guardan 5 . [ibid.: 154; grifos meus]

Para Serrani (ibid.: 154), a indeterminação do sujeito nas expressões com se não é absoluta, e tem sua extensão semântica delimitada pelo próprio contexto lingüístico: a circunstância de lugar en casa e a desinência verbal em pudimos restringem o hábito à família da autora da carta. A construção com se, segundo Serrani (ibid.), "funciona dando um tom proverbial ao discurso, porque o costume é apresentado como modelo de conduta": caso a destinatária faça uma leitura de acordo com a estratégia argumentativa proposta pela autora da carta, esse modelo dificilmente será questionado.

Serrani (ibid.: 155-156) classifica os discursos presentes nos textos analisados como do tipo autoritário ${ }^{26}$, nos quais as construções se-verbo exprimem generalizações associadas ao bom senso (A), ao costume (B), à moda (C) e a um tom proverbial (D) apoiado na tradição. A autora (ibid.) conclui que o funcionamento discursivo do se nesses discursos elimina a participação do destinatário na constituição semântica dos textos, bloqueando uma real interação por meio da linguagem; em suma, as construções se-verbo analisadas são, na realidade, mascaramentos de ordens que o locutor quer impor ao seu destinatário. Finalizando, é preciso salientar que, em momento algum do seu trabalho, Serrani faz referência à natureza passiva ou ativa dos enunciados que analisou: preocupou-se unicamente com seu aspecto impessoal. Apesar disso, comentei a análise da autora porque alguns dos enunciados que cita e examina poderiam funcionar como construções passivas (por exemplo, Ahora se usan éstos [pantalones] (ibid.: 153)) para as quais seriam válidas, portanto, as conclusões apresentadas.

Alguns dos estudos aos quais me refiro ao longo desta seção fazem referência explícita ao caráter marcado das passivas no Espanhol. E, em se tratando da passiva perifrástica, pode-se dizer que é uma estrutura ainda mais marginal. Entretanto, a mera observação da língua espanhola em funcionamento nos revela que a passiva perifrástica parece ter encontrado um terreno profícuo: os gêneros textuais associados à informação, especialmente

\footnotetext{
${ }^{26}$ Segundo tipologia de Orlandi (1978 e 1980).
} 
aqueles presentes nos meios de comunicação escrita (jornais, revistas, páginas web, folhetos, etc.). Há lingüistas que enxergam no fenômeno uma influência negativa do Inglês no Espanhol, e por isso mesmo recomendam a restrição do uso da passiva nessas situações. É o caso de Lorenzo (1980:19), ao afirmar:

Vistos los hechos como fenómenos supraculturales, es indudable que la preponderancia actual del inglés amenaza, como hemos señalado repetidas veces, el equilibrio funcional alcanzado por estas lenguas que en mayor o menor grado están sometidas a su influencia. Así, en lo que atañe al español, donde la fórmula ser + participio causa serias ambigüedades que no hemos hecho más que apuntar, la ignorancia o el apresuramiento de los traductores (tanto los de libros, como los de cine y televisión) condena al ostracismo o al olvido a una gran parte del rico inventario de soluciones de que dispone el español para reflejar la omnipresente inglesa to be + participio, hasta tal punto, que la reciente fórmula to be + being + participio (the house is being built) que resuelve a menudo la ambivalencia de the house is built, se hace cada día más frecuente en español, que disponía ya de la casa es construida, están construyendo la casa y la casa la están construyendo, se construye la casa, para adoptar el calco la casa está siendo construida, atestiguable incluso en escritores de notable corrección académica.

\title{
Opinião semelhante tem Romero Gualda (1996:38-39), em sua obra
} sobre o Espanhol nos meios de comunicação:

\begin{abstract}
La traducción del inglés al castellano, muy frecuente y necesaria en la actividad periodística, ha traído al español bastantes construcciones que, sin ser absolutamente extrañas a nuestro sistema lingüístico, sí serían menos frecuentes sin esa influencia extranjera. Sabemos que el castellano tiene preferencia por la expresión activa y de ahí todas las complejas formas presididas por el pronombre SE a las que acudimos cuando no podemos transformar un complemento agente en sujeto: "Las tierras son abandonadas" = "Se abandonan las tierras", "Los estudiantes son ayudados con becas" = "Se ayuda a los estudiantes con becas"; no quiere decir esto que no puede usarse la voz pasiva en español pues es un recurso expresivo más al que no debe renunciar el periodista sino que debe emplearlo bien. Han de evitarse traducciones del tipo: "Ha sido decidida por el claustro la ampliación del periodo de exámenes" [mejor, "el claustro ha decidido la ampliación del periodo de exámenes"], o alguna más admirable e impensable como la citada por Manuel Seco: "En Palestina, un anciano falleció después de haber sido disparado.”
\end{abstract}

Talvez haja exagero nas palavras de Lorenzo quanto ao ostracismo e ao esquecimento do rico y matizado inventario de soluciones alternativas à passiva perifrástica no Espanhol, dado que o autor não apresenta dados quantitativos que corroborem sua afirmação. Romero Gualda, por sua vez, parece dar ao tema um tratamento exclusivamente prescritivo: aponta usos pouco habituais da passiva que, sendo estrangeirismos, não refletem o buen 
empleo da estrutura e por isso devem ser evitados. A autora não entra em detalhes sobre o que considera o bom uso das passivas, porém fica claro que está mais preocupada com a observação da norma que com uma reflexão sobre os usos, valores e freqüências dessas construções na língua espanhola, bem como sobre os efeitos de sentido que produzem.

Pensando sobre essas e outras questões relativas às passivas, o caminho que considero mais recomendável é fazer uma descrição acurada (quantitativa e qualitativa) das passivas no Espanhol a partir de amostras de uso da língua em textos autênticos, buscando identificar nelas padrões lexicais e sintáticos referentes ao objeto de análise. Não me foi possível fazê-la neste trabalho nem para o Espanhol, nem para o PB; apenas o corpus de aprendizes brasileiros de E/LE foi descrito e analisado conforme esses critérios. Entretanto, a título de ilustração, comento o estudo que fiz em Araújo Júnior $(2004: 261-277)^{27}$, ao descrever e explicar, através da Lingüística de Corpus (LC), os usos passivos do verbo pensar no Espanhol. A razão de escolha desse verbo deveu-se ao fato de o mesmo admitir tanto construções transitivas quanto intransitivas. Ademais, o verbo em questão parecia ser bastante produtivo em construções intransitivas (El hombre es un animal que piensa; El director nunca piensa sobre los problemas; Me ha dicho que piensa en mí todos los días) e em outras que usualmente não admitem passivização (Pienso que deberías volver a tu país; Pienso marcharme ahora mismo), o que me levava a supor, em princípio, uma baixíssima incidência de passivas. Utilizei como corpus de referência o $\operatorname{CREA}^{28}$ e, após analisar as concordâncias para

\footnotetext{
${ }^{27}$ Este estudo foi realizado como trabalho de aproveitamento da disciplina do mestrado "Introdução à Lingüística de Corpus” e posteriormente selecionado para publicação na Crop (Revista da Área de Língua e Literatura Inglesa e Norte-Americana do DLM/ FFLCH - USP).

${ }^{28}$ Corpus de Referencia del Español Actual, projetado e mantido pela Real Academia Española (RAE), com um total de 134.571 documentos e aproximadamente 150 milhões de palavras. Está disponível para consulta gratuita no site http://corpus.rae.es/creanet.html . Na composição desse corpus entraram textos completos - tanto escritos (90\%) quanto orais (10\%) — , coletados a partir de 1975. Também no intuito de garantir um quadro representativo da língua espanhola no mundo, o CREA reserva $50 \%$ dos textos para a variante peninsular e dedica os outros $50 \%$ para as demais variantes (especialmente as americanas). No intuito de oferecer maior flexibilidade na obtenção de dados, o CREA está estruturado em diferentes módulos, o que torna possível que as consultas se refiram à totalidade dos textos ou unicamente àqueles que satisfaçam determinados critérios selecionados pelo usuário, por exemplo: CRONOLÓGICOS (trabalhar com apenas uma faixa temporal, por exemplo, de 1980 a 1990); GEOGRÁFICOS (trabalhar com uma só variante); MEIO (optar por textos publicados em jornais); TEMÁTICOS (escolher entre textos de ficção, científicos, artísticos, etc.). Apesar dessas vantagens, o sistema apresenta limitações referentes à quantidade de documentos recuperáveis — que está limitada a 2000 — , assim como à
} 
todas as consultas e agrupar os dados ${ }^{29}$, encontrei os seguintes padrões para os particípios de pensar:

(1) [ser + particípio (pensado/a/os/as)], incluindo a conjugação de ser com tempos simples (Muchos de los pisos modernos fueron pensados para los que viven solos.) e com tempos compostos (Este manual ha sido pensado para iniciantes.);

(2) [verbo + infinitivo de ser + particípio (pensado/a/os/as)] (Nada de esto pudo ser pensado por la generación precedente.) ;

(3) [estar + particípio (pensado/a/os/as)], incluindo a conjugação de estar com tempos simples (Todas sus decisiones están pensadas para favorecer a los inversionistas.) e com tempos compostos [apenas 1 ocorrência: (...) los centros de reunión de estas personas han estado pensados (arquitectónicamente) para estas actividades (...) ];

(4) [verbo + infinitivo de estar + particípio (pensado/a/os/as)] (Sus obras parecen estar pensadas para un público más exigente.);

(5) [verbo (diferente de ser e estar) + particípio (pensado/a/os/as)] (La propuesta viene pensada desde hace mucho.);

(6) particípio (pensado/a/os/as) com sentido passivo (Es una exposición pensada para ser itinerante.);

(7) [tener + particípio (pensado/a/os/as)] (No son exactamente las vacaciones que teníamos pensadas.);

(8) advérbio mal + particípio (pensado/a/os/as), equivalente a um adjetivo ( $Q$ Qué mal pensada! );

(9) advérbio menos + particípio (pensado/a/os/as), equivalente a um adjetivo (El día menos pensado te van a echar del trabajo.).

quantidade de exemplos, restrita aos primeiros 1000 de cada consulta. No caso de uma consulta para a qual o número de documentos/exemplos exceda o limite, o sistema oferece a possibilidade de filtragem (por documentos ou por casos), de maneira que o usuário tenha uma amostra representativa.

${ }^{29}$ Trabalhei apenas com a variante peninsular em enunciados escritos, porém sem restrições cronológicas, de meio ou de tema. Também restringi minha pesquisa e análise às passivas com particípio, excluindo assim as pronominais. Optei por excluir as pronominais porque teria sido necessário incorporar à análise as estruturas impessoais (que muitas vezes se confundem com as passivas pronominais), aumentando em muito o escopo do trabalho. 
As ocorrências de cada padrão podem ser visualizadas na figura 1:

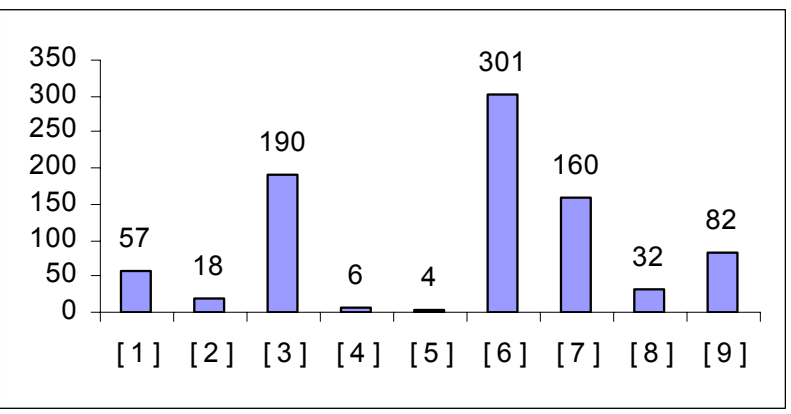

Figura 1: Padrões observados e suas ocorrências no corpus

Os padrões (7), (8) e (9) não foram considerados por mim como sendo estruturas passivas. No caso de (7), a estrutura tener + particípio expressa uma idéia próxima aos tempos compostos (haber + particípio), porém com um matiz de concretude que enfatiza o resultado da ação ${ }^{30}$ :

Antes de esa intervención médica, Gallagher estaba planeando su retorno. El músico tenía pensado ofrecer una gira por el Reino Unido e Irlanda antes de iniciar su visita al resto de Europa. [CREA/España: La Vanguardia, 16/06/1995 (PRENSA), Tema 04: Música]

Embora o padrão (7) contenha um particípio com sentido passivo, não considero a construção como sendo passiva: ao cotejá-la com os padrões anteriores (1 a 6), em todos eles o agente ou é suprimido ou aparece no final do enunciado; inclusive, pode-se apontar a ausência de protagonismo dessa entidade como característica das passivas. No caso de (7), a presença de um particípio com sentido passivo não faz com que o sujeito/agente seja eliminado ou transferido para a posição final; nesse sentido, (7) está mais próximo das construções transitivas.

\footnotetext{
${ }^{30}$ Nesse sentido, podemos considerá-la como uma perífrase de resultado, como o fazem alguns autores como Matte Bon (1995:101). Tal perífrase não é exclusiva do verbo pensar, ocorrendo com a maioria dos verbos, especialmente os transitivos. Apesar de esse padrão estar fora do nosso escopo, vale a pena ressaltar que o mesmo ocorre 160 vezes no corpus de estudo, em torno de 5\% das incidências; se considerássemos o uso de tener com outros particípios, esse percentual seria ainda maior. Por isso mesmo, parece-nos curioso que essa estrutura esteja ausente dos livros didáticos de E/LE, uma vez que parece ser bastante utilizada na língua espanhola, como revela o corpus.
} 
Os padrões (8) e (9) possivelmente continham traços passivos na origem, porém atualmente são expressões adjetivas (ou atributivas) fossilizadas, que integram o repertório fraseológico da língua espanhola. No caso de (8), a expressão mal pensado/a/os/as pode ser traduzida como "desconfiado/a", "malicioso/a", "maldoso", "que pensa mal de algo/alguém", e ocorre junto a nomes ou como atributo:

Quien sabe, a lo mejor es para tapar todo lo que salga mal, o para ocultarse de la mirada severa del señor ministro que tiene las riendas de la economía. O puede ser, y será un simple error, que hay que ver qué mal pensada es la gente. [CREA/España: ABC, 24/12/1983 (PRENSA), Tema 03: Política]

Em se tratando de (9), menos pensado/a/os/as aparece freqüentemente com palavras relacionadas a tempo (preferencialmente com día) para indicar que o fato ao qual nos referimos ocorrerá de maneira inesperada ${ }^{31}$ :

Ya no podemos negar la existencia del SIDA, ya que no es posible seguir ocultando la cabeza como dicen que hace el avestruz, preferimos creernos que por "arte de magia", el día menos pensado, la pesadilla habrá concluido. [CREA/España: 1987, Lorenzo, Ricardo; Anabitarte, Héctor; Tema 06: Salud]

Nas 82 incidências de (9), a expressão menos pensado/a/os/as apresenta o mesmo comportamento: acompanha invariavelmente um nome. Portanto, devido a esse notório caráter adjetival, não considero (9) uma construção passiva.

Com a exclusão dos padrões (7), (8) e (9), restaram-me 576 ocorrências de passivas no corpus. Um resultado surpreendente, se levadas em conta minhas hipóteses iniciais, porém dentro do esperado ao pensarmos na freqüência de ativas e passivas: uma estimativa para as formas ativas do verbo pensar, também através de pesquisas no $\mathrm{CREA}^{32}$, fornece aproximadamente 28.346 casos; portanto, uma conta simples nos revela percentuais de $98 \%$

\footnotetext{
${ }^{31}$ O padrão (9) ocorre 82 vezes no corpus de estudo (cerca de 2,6\% das incidências). Portanto, vale aqui o mesmo comentário feito anteriormente para tener + particípio: apesar da freqüência considerável, esse padrão não aparece nos livros didáticos consultados. É curioso que tampouco esteja registrado no dicionário RAE (2001) ou em outros consultados, como o VOX (1997) e o Clave (2000); a única exceção foi o María Moliner (2001).

${ }^{32}$ Para essa pesquisa, utilizamos formas lematizadas do verbo (piens*, pensab*, pensar* e pensas*) e em alguns casos tivemos que entrar com as próprias formas do verbo (pensamos, pensáis, pensó, etc.). Isso se deveu ao fato de que o corpus de referência não dispõe de uma versão marcada morfologicamente, que nos permitisse selecionar apenas as formas verbais (excluindo automaticamente as não verbais, como pensamiento/s, pensador/a/es/as, pensativo/a/os/as, pensión, pensionista/s, etc).
} 
para as ativas e apenas $2 \%$ para as passivas com particípio, o que vem ratificar o caráter da passiva como uma estrutura marcada. Vale recordar que nesse estudo não foi investigada a passiva pronominal (com o pronome se, ou pasiva refleja) com pensar. É certo que, caso fossem computadas as pronominais, aumentaria o percentual de passivas no corpus; ainda assim, tal acréscimo pouco afetaria os resultados, já que a preferência dos hispanofalantes parece ser mesmo pelas construções ativas ${ }^{33}$. Dessa forma, o manejo de um corpus de referência possibilitou-me tanto a confirmação de hipóteses já lançadas sobre o assunto, quanto a revelação de novos padrões de uso das passivas.

\title{
I.3. Acerca das passivas no PB
}

Os estudos sobre as passivas realizados por lingüistas brasileiros foram centrados menos na forma que nos valores e usos dessas estruturas. Said Ali (1971:176-177), ao tratar o assunto, assim escreve:

\begin{abstract}
O sujeito de verbo transitivo pode ser considerado não somente como ponto donde parte a ação, mas ainda como o ponto para o qual a ação se dirige; e neste segundo caso se empregará o verbo no particípio do pretérito combinado com o auxiliar ser. Diz-se então que o verbo denotador da ação está na voz passiva, e que o sujeito é paciente, como nesta frase - $a$ ave foi ferida pelo caçador; e chama-se, pelo contrario, voz ativa, com sujeito agente, à conjugação simples, como em — o caçador feriu a ave. Por extensão, diz-se que está na voz ativa, ou que tem forma ativa, todo o verbo usado nos diversos tempos e modos de conjugação simples.
\end{abstract}

Até este ponto, nada distinto do que consta nas gramáticas e livros didáticos de língua portuguesa editados no Brasil. Entretanto, logo após essa definição, Said Ali (ibid.:177) apressa-se em esclarecer que tal classificação, embora facilite o estudo das formas ${ }^{34}$, nem por isso se harmoniza sempre

\footnotetext{
${ }^{33}$ Pode-se comprová-lo pelo estudo realizado por Barrenechea \& Manacorda de Rosetti (1979:65) para o Espanhol falado em Buenos Aires, para o qual as ativas ocorrem em 97,81\% dos casos. Como se pode ver, tais resultados estão muito próximos aos que obtivemos com a análise dos dados do CREA, para a variante peninsular.

${ }^{34}$ Grifo meu.
} 
com a significação do verbo. Então dá exemplos de verbos intransitivos (padecer, adoecer, morrer, envelhecer, durar) nos quais não se revela "(...) nenhuma atividade da parte do sujeito". E conclui:

São atos que nele se consumam, estados pelos quais passa, sem que para isso concorra o seu esforço. A condição do sujeito aqui é a de paciente. Estoutros intransitivos, ainda que tenham forma ativa, aproximam-se pois, quanto à significação, antes dos transitivos passivos que dos transitivos ativos.

Na verdade, nem precisaríamos nos limitar aos verbos intransitivos: o PB possui muitos verbos que, na forma ativa, têm um sujeito cujo papel temático não é o de agente ${ }^{35}$ — na frase João odeia engarrafamento, o sujeito (João) não desencadeia o processo (daí não ser agente/desencadeador), mas sim é afetado por ele. Ao falar do caráter passivo de determinados verbos usados na forma ativa, Said Ali inclui o significado e, portanto, a semântica, no tratamento das passivas. Apesar dessa reflexão importante, nas gramáticas e livros didáticos de língua portuguesa - cuja ênfase é na forma, conforme já comentei - ainda se busca, ao que parece, separar a sintaxe da semântica. Vejamos o que diz Bechara (1976: 105):

É preciso não confundir voz passiva e passividade. Voz é a forma ${ }^{36}$ especial em que se apresenta o verbo para indicar que a pessoa recebe a ação: Ele foi visitado pelos amigos. / Alugam-se bicicletas. Passividade é o fato de a pessoa receber a ação verbal. A passividade pode traduzir-se, além da voz passiva, pela ativa, se o verbo tiver sentido passivo: Os criminosos recebem o merecido castigo. Portanto nem sempre a passividade corresponde a voz passiva.

A análise semântica é o destaque no estudo que Massoni \& Martim (1985) fizeram sobre as passivas com "ser" no PB (a partir da Teoria de Casos de Fillmore ${ }^{37}$ ), no qual afirmam que "(...) a passiva é um problema sintáticosemântico, onde estão implicadas as relações entre o predicador e os argumentos, na frase como um todo" (ibid.: 49). Segundo as autoras, a

\footnotetext{
35 É o caso, por exemplo, dos verbos psicológicos. Na definição de Cançado (2002: 94), os verbos psicológicos são aqueles "que denotam um estado emocional e têm, obrigatoriamente, um argumento experienciador.” Alguns dos verbos classificados pela autora como psicológicos: admirar, adorar, desejar, respeitar, odiar, etc.

${ }^{36}$ Grifo meu.

${ }^{37}$ As autoras não indicam a data de publicação do trabalho de Fillmore.
} 
transformação passiva só poderá ser aplicada a uma oração que contenha pelo menos dois argumentos, sendo que o argumento sujeito deverá ter o traço [+atividade] (que não implica necessariamente a presença do traço [+animado]: $O$ vento abriu a porta transforma-se sem problemas em A porta foi aberta pelo vento) e o argumento complemento deverá ser afetado por essa ação ([+afetado]). Massoni \& Martim (ibid.) também analisam problemas referentes à transitividade, em alguns casos apontada por elas como uma condição insuficiente para a conversão de uma ativa numa passiva. Dessa maneira, enunciados como:

(1) Meu pai tem dois carros.

(2) O cavalo abanou o rabo.

têm verbos transitivos (ter e abanar), porém, se convertidos em passivas, resultam agramaticais:

(3) *Dois carros são tidos por meu pai.

(4) ${ }^{\star}$ O rabo foi abanado pelo cavalo.

Ou seja, além da transitividade, as características semânticas do predicador e dos seus argumentos precisam ser levadas em conta. No caso de (2), o agente e o paciente representam uma única entidade referencial, já que rabo representa uma parte inalienável de cavalo; um predicado nessas condições bloqueia a construção passiva.

Camara (1989: 187-188), ao tratar as construções passivas, parece preocupar-se com o seu funcionamento não apenas sintático, mas também discursivo. Vejamos o seguinte fragmento:

(...) a essência da voz passiva (sob qualquer de suas formas) é o realce do processo ativo em detrimento do agente, que é omitido ou esporadicamente incluído no predicado. O lugar de sujeito, que ele ocupa na voz ativa, é preenchido pelo paciente (quando o verbo é transitivo), ou fica vago num tipo de voz impessoal de forma passiva, que justifica a velha frase do etnólogo inglês Condrington, já assinalada neste sentido por Trombetti: "o que mais se aproxima de um verbo passivo é um verbo ativo usado impessoalmente” (Trombetti, 1923: 291).

Ou seja, Camara considera como característica das passivas a tendência à omissão do agente (figura esporadicamente, fica vago ou simplesmente desaparece da expressão). Ora, numa passiva, a presença de um agente 
(como foco, por exemplo) ou seu apagamento (seja intencional ou não), assim como o alçamento de um paciente, são questões que muitas vezes extrapolam os limites da oração e devem ser pensadas a partir do discurso. Da mesma forma, a ambigüidade entre as estruturas passivas e as impessoais (também mencionada por Camara) pode ser mais bem interpretada de um ponto de vista discursivo.

Camacho (2000) adota perspectiva idêntica à de Camara, num estudo no qual estabelece distinções funcionais entre as passivas e as impessoais. Nesse trabalho, reconhece a existência de duas construções de voz em Português: voz passiva e voz impessoal. Assim as define (ibid.: 217-18):

(...) A passiva, também chamada analítica, é constituída por auxiliar, em qualquer um de seus tempos verbais, e um particípio passado, seguido ou não de um SP agentivo.

A impessoal, também chamada passiva sintética, é constituída pela fórmula verbo na $3^{\text {a }}$ pessoa da forma ativa combinada com o pronome se, na chamada função de apassivador, que é como tradicionalmente se qualifica o clítico, quando se reporta a um sujeito de $3^{\mathrm{a}}$ pessoa que, na representação lingüística, não figura como Sujeito ativo.

Portanto, Camacho (ibid.) apresenta uma definição pouco distinta daquela presente nas gramáticas tradicionais. Contudo, problematiza esse conceito ao afirmar que nem todas as construções impessoais contêm o "se", cuja eliminação acompanha a perda de clíticos já atestada no $\mathrm{PB}^{38}$. O autor ilustra com exemplos do PB oral ${ }^{39}$ :

(5) faz esse refogado e põe tomate, um ou dois tomates (D2-POA291:129)

(6) então, naquele arroz mexe, quebra dois ovos aí e, e depois então comprime esse arroz num pirex (D2-POA-291)

Camacho (ibid.) também comenta que o argumento único do predicado na construção impessoal nem sempre se comporta como sujeito real: além de ocupar uma posição destinada ao objeto, nem sempre se mantém a

\footnotetext{
${ }^{38}$ Para a perda de clíticos, o autor cita os trabalhos de Kato \& Tarallo (1986).

${ }^{39}$ Os exemplos (5) e (6) foram extraídos do corpus compartilhado do Projeto de Gramática do Português Falado, que consiste numa amostragem do material coletado pelo Projeto da Norma Urbana Culta (Nurc)/Brasil, gravado com informantes cultos procedentes de Recife, Salvador, Rio de Janeiro, São Paulo e Porto Alegre.
} 
codificação morfossintática que regula o comportamento nominativo próprio do sujeito $^{40}$. Afirma o lingüista:

Cria-se, assim, uma espécie de voz ativa impessoal indeterminadora, em que o argumento Paciente não recebe função de Sujeito, cuja posição fica marcada formalmente pela presença do clítico "se".

Em seu estudo, Camacho (ibid.) proporciona uma caracterização semântica e pragmática das construções passiva e impessoal, a partir dos fatores detransitividade, impessoalidade e topicalidade ${ }^{41}$. No âmbito da semântica, aponta como correlação significativa entre as construções passiva e impessoal o fato de ambas estarem fortemente condicionadas pela presença de um verbo de Ação, em detrimento de predicados de Processo, Posição e Estado. Para esse autor, um aspecto semântico importante que distingue essas duas construções está associado à transitividade: a estrutura ativotransitiva se mantém na construção impessoal, aliviando a restrição motivada pela necessidade de distinção entre os participantes, que é própria da passiva. Conforme exemplo fornecido pelo autor:

(7) a. João levantou o braço.

b. ?O braço foi levantado por João.

Camacho (ibid.) afirma que os argumentos (João e braço) representam a mesma entidade (já que braço constitui uma parte inalienável de João) e, portanto, possuem grau baixo ou nulo de distintividade ${ }^{42}$. Para o lingüista, a conseqüência mais evidente dessa propriedade semântica para a organização sintática é o bloqueio da construção passiva (7b), o que não se aplica à construção impessoal:

(8) levantou-se muito o braço na assembléia para votar tantas propostas.

\footnotetext{
${ }^{40}$ Por exemplo, a concordância. Nessas construções, é muito freqüente a perda da concordância entre a forma verbal e o sujeito.

${ }^{41}$ Nas palavras do autor, topicalidade é a "atribuição da função de Tópico a um argumento não-Agente." O termo tópico, usado pelo autor, está conforme a teoria funcional de Simon Dik (1989); neste trabalho, para essa função, uso o termo tema, de acordo com a definição de M. A.K. Halliday (1976). Igualmente, chamo de tematização o que Camacho define por topicalidade.

${ }^{42}$ Ver comentário sobre exemplo (4), neste capítulo.
} 
Ainda no campo da semântica, Camacho (ibid.) considera a construção passiva "prototipicamente sensível à promoção de entidades afetadas à posição de Sujeito/Tópico e à detransitividade do predicado verbal, e não necessariamente à impessoalidade do Agente". Segundo o autor, nesse aspecto, as impessoais são taxativas e não permitem a manifestação formal de um SN agentivo. Isso é mostrado a partir dos exemplos:

(9) a. João quebrou o vidro da janela.

b. O vidro da janela foi quebrado (por João).

c. O vidro da janela (se) quebrou (?por João).

Em termos pragmático-discursivos, Camacho (ibid.) afirma que a preferência pela construção passiva é motivada pela "determinação pragmática de constituir um Tópico", o que não se aplica à impessoal, "em que o processo é apresentado em si mesmo, independentemente de uma entidade que lhe sirva de referência".

Em sua análise das construções com se, Indursky (1993) considera o funcionamento do clítico como uma fronteira entre a sintaxe e o discurso ${ }^{43}$. Segundo a autora, a única marca formal que distingue o "se" apassivador (alugam-se casas, que fornece a paráfrase passiva casas são alugadas) do "se" indeterminador" (aluga-se casas) é a concordância verbal, que se faz no primeiro caso e não no segundo ${ }^{45}$. Nas construções transitivas em que o verbo e o SN estão no singular (vive-se uma situação de pânico na periferia carioca), a concordância verbal perde esta propriedade opositiva e o "se" é passível de receber uma dupla interpretação: tanto pode ser apassivador como indeterminador. A autora analisa alguns enunciados para corroborar essa

\footnotetext{
${ }^{43}$ Indursky analisa primeiramente as construções com "se" , do ponto de vista da sintaxe, segundo os parâmetros da Teoria de Regência e Ligação de Chomsky. Na seqüência, coteja essa análise formal do "se" com uma interpretação discursiva.

${ }^{44}$ Aqui é preciso comentar que na nomenclatura gramatical brasileira as construções com "se” sem sujeito explícito se classificam como indeterminadas e não impessoais, como acontece no Espanhol.

${ }^{45}$ A autora endossa o que normalmente aparece nas gramáticas normativas e em muitos estudos sobre a relação entre as construções passivas e as impessoais: a concordância verbal é usada nesse caso como critério de distinção entre uma e outra - como no estudo de Barrenechea \& Manacorda de Rosetti (1979) sobre as passivas no Espanhol falado em Buenos Aires. Embora facilite a classificação das estruturas com se em passivas ou impessoais, tal critério não é isento de problemas, admitindo-se que no PB é muito freqüente a perda de concordância entre o verbo e o SN nas construções com o pronome "se".
} 
afirmação, dos quais tomamos um como exemplo, extraído de um artigo escrito por Fernando Henrique Cardoso ${ }^{46}$ :

(10) Os casos [de violência e corrupção] são tantos e tão freqüentes que se está criando um clima de susto, de descrença.

A interpretação do "se" como apassivador pode ser parafraseada como:

(10) a. Um clima de susto, de descrença está sendo criado.

Para Indursky (ibid.), esta leitura do se permanece nos limites da oração e somente põe em evidência a forma verbal cuja voz é passiva. Outra análise pode ser feita a partir da paráfrase:

(10) b. Alguém está criando um clima de susto, de descrença.

De acordo com Indursky (ibid.), esta segunda leitura põe em relevo que o agente da ação está indeterminado e "(...) instiga o leitor a questionar o texto para preencher a lacuna produzida pelo pronome indeterminador: se alguém está criando tal clima, quem é esse alguém?". Dessa forma, ao interpretarmos o "se" como pronome apassivador, resolveríamos questões próprias da sintaxe (projeção de argumentos, atribuição de casos e papéis temáticos) e não haveria espaço para refletir sobre a indeterminação, pois embora o agente não se realize lexicalmente, seu papel temático fica preservado ao ser absorvido por "se". Por outra parte, ao interpretar o "se" como indeterminador, ultrapassamos essa fronteira para refletir a partir do discurso e as questões passam a ser outras: se o agente indeterminado está implícito no texto, se está elidido, se o cotexto nos dá pistas de como recuperá-lo ou se temos que buscálo fora dos limites textuais.

Entretanto, há lingüistas que rejeitam a classificação do "se" como pronome apassivador. É o caso, por exemplo, de Said Ali (apud Bagno, 2000: 219), que atribui ao "se" a função de sujeito nas ditas passivas pronominais:

\footnotetext{
${ }^{46}$ O título do artigo é “Crime e Castigo”, e foi publicado na Folha de São Paulo, p. 1.2, de 01/08/91. Cf Indursky (op. cit.), nesse artigo o autor examina os sintomas de degenerescência da sociedade brasileira.
} 
“(...) se fizermos abstração da gramática e, procedendo unicamente à análise psicológica, consideramos que os termos psicológicos só têm que ver com as idéias que as palavras atualmente simbolizam". Segundo Bagno (ibid.: 220), "hoje no lugar de 'gramática', escreveríamos sintaxe, e no lugar de 'análise psicológica' , escreveríamos análise semântica." Para Bagno, enquanto Said Ali tenta reunir os critérios sintático e o semântico no estudo do problema, os gramáticos prescritivistas se equivocam exatamente por ir na direção oposta: além de separar esses dois critérios no momento de classificar a partícula "se", menosprezam também os aspectos pragmáticos do fenômeno. Bagno (ibid.) ilustra sua afirmação citando o comentário de Monteiro acerca do par Fuma-se aqui/Fuma-se charuto aqui:

Ensinam os gramáticos que, na primeira oração, o sujeito está indeterminado, ao passo que na segunda é o termo charuto que desempenha esta função. O paradoxo é por demais evidente: quando afirmam que o sujeito de "fuma-se aqui" é indeterminado, utilizam um critério semântico, uma vez que o SE é interpretado como referente a alguém ( "que não queremos ou não podemos nomear" ); quando, por outro lado, dizem que o sujeito de "fuma-se charuto aqui” é charuto, lançam mão de um critério sintático, baseado na predicação e na regra de concordância.

Na seqüência, Bagno (ibid.) destaca a relevância do critério semântico para uma análise adequada das construções com "se" :

\footnotetext{
O aspecto semântico sistematicamente desprezado pelos normativistas é que, em todas as orações deste tipo, os verbos presentes são sempre verbos que só podem ser praticados por um sujeito com traço semântico [+humano]. Só seres humanos podem fumar, assim como em aluga-se salas, joga-se búzios, vende-se ovos, avia-se receitas, amola-se facas etc., todos os verbos exigem (além de um óbvio objeto direto) um sujeito [+humano]. E é essa poderosa evidência semântica que leva os falantes a manter esses verbos no singular, fazendo eles concordarem com o sujeito indeterminado, indicado na superfície do enunciado pelo clítico SE.
}

Portanto, nas construções com "se" , o autor defende a interpretação do pronome como um recurso de que a língua dispõe para indicar a indeterminação do sujeito; também rejeita categoricamente a interpretação do clítico como índice de passiva, e considera inadequadas as denominações "se apassivador", "passiva sintética" e "passiva pronominal". Mais adiante, Bagno (ibid.: 221-222) ressalta o caráter marcadamente nominativo do "se" no PB, ao 
ponto de os falantes só o admitirem como acusativo em construções na voz reflexiva e predominantemente quando o sujeito apresenta o traço [+ animado] ( $A$ atriz olhou-se no espelho antes de subir ao palco); em razão disso, o autor aponta o freqüente apagamento do "se" em construções como $A$ porta se fechou (A porta fechou), O vaso se quebrou ( $O$ vaso quebrou), nas quais os sujeitos são [-animados] ${ }^{47}$.

Duarte (1990), após fazer uma análise funcional das passivas do PB e do Inglês, conclui que a função básica das passivas nessas línguas está diretamente ligada ao processo de destituição ou obliteração do sujeito/agente, que passa a designar como a função de detematização do sujeitolagente; tal processo se dá por meio da omissão do agente ( $O$ traficante foi detido) ou da recodificação do mesmo - seja realizado através de sintagma preposicional em posição de foco sentencial ( $O$ traficante foi detido por agentes federais), seja realizado pelo clítico nas passivas pronominais (Prendeu-se o traficante); outra função apontada pela autora é a tematização, "(...) ilustrada nas passivas em que um não AGENTE é promovido para a posição inicial, temática" (ibid.: 164).

Moino (1989) inova ao estudar as passivas no PB do ponto de vista da sociolingüística. Na primeira parte de sua análise, faz uma breve descrição dos distintos tipos de passivas de particípio através do modelo de Regência e Vinculação de Chomsky. Na segunda parte, dedica-se a constatar a distribuição dessas construções nos discursos oral e escrito, assim como as estratégias formais para substituição das mesmas; para tanto, adota o modelo sociolingüístico variacionista e fundamenta-se nos trabalhos de Labov e Tarallo.

Moino (ibid.:36) divide as passivas de particípio em dois grupos: as passivas sintáticas e as passivas lexicais. As passivas sintáticas são formadas por uma perífrase de verbo ativo - em geral "ser" - mais particípio (Os

\footnotetext{
${ }^{47}$ Segundo Bagno, são as construções chamadas pelos normativistas de pseudo-reflexivas, "nas quais um sujeito [-animado] 'pratica' uma 'ação' que incide sobre si mesmo” (as palavras pratica e ação entre aspas são mostra da evidente ironia do autor acerca das definições da gramática normativa, que julga muitas vezes inadequadas). Bagno também reforça sua afirmação dando exemplos de verbos que podem suscitar construções reflexivas com "se" , quando o sujeito é [+animado] (Luísa se desligou do partido em 1990.), e ergativas, quando o sujeito é [-animado] (Essa tecla permite que o televisor desligue automaticamente.).
} 
passageiros foram avisados do atraso do vôo.), e têm comportamento marcadamente verbal (traço $[+\mathrm{V}]$ ). Já as passivas lexicais têm valor de adjetivo $^{48}$ e ocorrem normalmente dentro do SN (O primeiro-ministro do Iraque, lyad Allawi, autorizou neste domingo a reabertura de um polêmico jornal fechado pelos Estados Unidos em março. [O Estado de São Paulo, 19/07/2004] ) ou em aposição ao SN (A lei, aprovada no ano passado por um período inicial de um ano, foi ampliada por seis meses. [O Estado de São Paulo, 19/07/2004] ). Ao analisar os dados de sua pesquisa, Moino constatou, em todas as categorias consideradas (escolaridade, faixa etária e sexo), uma freqüência superior das passivas lexicais com relação às sintáticas e às pronominais. A pesquisadora considera que esses resultados parecem apontar para uma possível lexicalização da estrutura e que, talvez, muitas delas "nem sejam percebidas como passivas" (ibid.: 49). Voltarei ao trabalho de Moino no item subseqüente (I.4.), ao fazer uma análise contrastiva das passivas no PB e no Espanhol.

Conforme se observa a partir desse levantamento mínimo que fiz, o tema das passivas pode ser visto de várias perspectivas e segundo diferentes modelos de análise, dos que privilegiam a forma aos que focalizam os valores e sentidos dessas construções nos enunciados - além das análises nas quais se leva em conta a variação lingüística como fator importante na categorização (qualitativa e quantitativa) dos usos das referidas construções. Desde já deixo claro que, em meu trabalho, não tenho interesse em discutir se as passivas têm ou não uma forma peculiar no PB e no Espanhol: parto do pressuposto de que existem estruturas passivas em ambas, e que cumprem determinadas funções que pretendo analisar.

\footnotetext{
${ }^{48}$ Moino (ibid.:35) chama a atenção para o fato de que, há muito, o comportamento híbrido dos particípios passivos - mais adjetivais ou verbais - tem sido uma questão polêmica entre os gramáticos e lingüistas. Em seu trabalho, a autora segue a análise proposta por Chomsky (1981) para a questão.
} 


\section{I.4. As passivas no PB e no Espanhol: análise contrastiva}

\section{I.4.1. Sobre a proposta de análise}

Inicialmente, farei uma síntese do comportamento das passivas no PB e no Espanhol, concentrando-me nas tendências comuns e nas assimetrias que essas estruturas apresentam nas duas línguas. Para tal, utilizarei os trabalhos de Moino (1989) e Duarte (1990), referentes ao PB; no caso do Espanhol, farei uso das análises de Miñones \& Sánchez (1999), Miñones (2000) e Barbeito \& Miñones (2002). À exceção do trabalho de Moino, que aborda as passivas de uma perspectiva sociolingüística, todos os demais trazem análises funcionalistas e tratam o objeto levando em conta as relações sintáticas, semânticas e pragmáticas no discurso. Feita a síntese, analiso como se comportam as passivas na produção escrita de brasileiros aprendizes de E/LE.

\section{I.4.2. As construções predominantes no PB e no Espanhol}

De acordo com os estudos que mencionei em seções precedentes, as passivas no PB e no Espanhol possuem como característica comum a tendência a omitir o agente, em estruturas que, entretanto, revelam preferências distintas: enquanto no $\mathrm{PB}$ as passivas sintáticas e lexicais ${ }^{49}$ são mais abundantes que as com "se" ${ }^{\text {, o }}$, Espanhol mostra uma notória preferência pela construção pronominal.

A análise de Duarte (1990:150) para o $\mathrm{PB}^{51}$ obteve os percentuais de $62,8 \%$ para as passivas sintáticas ${ }^{52}$ e $37,2 \%$ para as passivas pronominais. A

\footnotetext{
${ }^{49}$ No Espanhol há construções semelhantes, conforme os exemplos extraídos do jornal Clarín, edição de 19/07/2004: El mando encabezado por Estados Unidos se negó a dar más detalles ; La proyección difundida por la red de televisión ATB- afirmaba que los bolivianos...

${ }^{50}$ Favorecido pela crescente perda do "se" no PB, fenômeno já comprovado em vários estudos como o de Kato e Tarallo (1986).

${ }^{51}$ Conforme exposto no item I.3., Duarte realizou uma análise funcional das passivas no PB e no Inglês, utilizando textos escritos. A metodologia empregada nesse estudo (Duarte, 1990: 150) foi a proposta por Krzeszowski, compreendendo quatro textos científicos, quatro textos jornalísticos e uma peça de teatro.
} 
análise sociolingüística de Moino (1989:44-45) para $\circ \mathrm{PB}^{53}$ fornece os seguintes valores:

a) passivas lexicais (32,6\% no oral e $29,7 \%$ no escrito);

b) passivas sintáticas ( $11,4 \%$ no oral e $13,5 \%$ no escrito);

c) passivas pronominais ( $1,9 \%$ no oral e $20,7 \%$ no escrito)

Surpreende $\mathrm{o}$ alto percentual das pronominais na modalidade escrita, superior ao das sintáticas. Seja como for, o que se pode concluir é que no PB existe uma preferência por estruturas passivas de particípio em ambas modalidades.

Para uma análise quantitativa das passivas no Espanhol, só tive acesso ao estudo de Barrenechea \& Manacorda de Rosetti (1979:65) para a modalidade oral em Buenos Aires. Segundo o levantamento feito por essas pesquisadoras, as passivas corresponderam a $2,18 \%$ do total, distribuídas em sintáticas $(27 \%)$ e pronominais $(72 \%)$. De acordo com esses números, fica clara a preferência pelas pronominais no discurso oral da variante portenha e, segundo autores como Kovacci (1977), essa tendência também se verifica no escrito. Com base nas referências bibliográficas que consultei, é possível extrapolar os resultados para as demais variantes do Espanhol; entretanto, é mais que recomendável confirmar esses percentuais por meio de novas análises e utilizando dados mais recentes. Atualmente, através da Internet, é possível tanto acessar dados de todas as variantes da língua espanhola como coletá-los e organizá-los em corpora eletrônicos; igualmente, graças aos

\footnotetext{
${ }^{52}$ A classificação de Moino me parece mais abrangente por considerar duas variedades de passivas de particípio: as sintáticas (com auxiliar, "ser” ou outros) e as lexicais (ver item I.3. para definição e exemplos). Duarte, porém, classifica as passivas somente em analíticas (com auxiliar + particípio) e mediais (pronominais, com o pronome "se"), não mencionando as lexicais; sem ter acesso ao corpus da autora, não foi possível saber se as lexicais foram desprezadas ou se enquadradas nas analíticas (considerando o auxiliar elidido, por exemplo). Para unificar a terminologia, nas referências ao estudo de Duarte utilizarei passiva sintática em vez de passiva analítica, assim como passiva pronominal em vez de passiva medial.

53 A metodologia empregada no estudo (Moino, 1989:40) considerou como variáveis externas a escolaridade, a faixa etária e o sexo dos informantes. Para a modalidade oral, foram utilizados 18 informantes, com gravações que seguiram rigorosamente o modelo laboviano de coleta de dados. Para a modalidade escrita, a autora utilizou como fonte de dados editoriais das revistas Veja e Isto é e dos jornais Folha de São Paulo e O Estado de São Paulo. No total, o estudo contou com 421 dados da modalidade escrita contra 411 da oral. Finalmente, para a análise do corpus, Moino tomou como variável dependente a passiva sintática, contrapondo-a às passivas lexicais, às orações ativas com verbo transitivo direto e às passivas pronominais.
} 
procedimentos e métodos da LC, torna-se mais fácil analisar corpora extensos e assim ter uma visão mais acurada do fenômeno em estudo.

\section{I.4.3. A presença vs. ausência de agente na estrutura}

Duarte (1990:151) computou 84,1\% de passivas sem agente. Já o estudo de Moino (1989:46) constatou a ausência quase que total do agente na modalidade oral e em $67,2 \%$ do corpus na modalidade escrita. A partir desses resultados, assumo que a omissão do agente é uma tendência nas construções passivas do PB.

No estudo de Barrenechea \& Manacorda de Rosetti (1979:68) para o Espanhol oral, não foi registrada uma só ocorrência de agente; tampouco foram computados agentes no estudo de Barbeito \& Miñones (2002), dedicado às passivas pronominais na escrita ${ }^{54}$. A análise de Miñones \& Sánchez (1999) para as passivas sintáticas em textos escritos ${ }^{55}$ forneceu $77 \%$ de ocorrências sem agente.

O estudo de Miñones (2000), também para textos escritos, revelou percentuais de $59 \%$ de passivas sintáticas com agente, contra $41 \%$ de passivas sintáticas sem agente explícito - uma diferença pequena, se comparada com as observadas nas demais análises que mencionei. A explicação para esses valores possivelmente está no corpus que a pesquisadora utilizou em seu trabalho, constituído de textos pertencentes a um só gênero: as notícias policiais ${ }^{56}$. Da mesma forma que em seu trabalho de 1999 (ver nota 55), a pesquisadora escolheu o gênero notícia policial porque este favorece o aparecimento do fenômeno que está investigando: as passivas sintáticas; o fato de que quase metade das incidências tenha agente expresso

\footnotetext{
${ }^{54}$ Barbeito \& Miñones (2002) constituíram um corpus com 30 artigos publicados nos jornais Clarín e La Nación (não informam o período da coleta), além dos 3 capítulos iniciais do livro La República Perdida.

${ }^{55}$ Segundo Miñones \& Sánchez (ibid.), o corpus para essa análise foi extraído de um livro infantil (Al Capitán de los duendes/ ECD) e de um livro de História (La República perdida/ LRP). A autora escolhe esses gêneros discursivos (no original, tipos discursivos) porque, segundo estudos prévios, favoreceriam um maior número de ocorrências da passiva sintática com relação a outros gêneros.

${ }^{56}$ Conforme Miñones (ibid.), o corpus para essa análise é composto de 30 notícias policiais extraídas do jornal Clarín, entre os meses de julho e outubro de 1999.
} 
nos sinaliza que, em determinados gêneros, sua presença é importante. Portanto, pensando numa quantificação geral, pode-se dizer que o Espanhol assim como o PB — também tende a suprimir o agente nas construções passivas. Porém, fica clara a necessidade de investigar essas estruturas levando em conta o gênero discursivo em que estão inseridas.

A omissão do agente nas construções passivas (tanto no PB como no Espanhol) em geral se dá por:

- menção prévia da entidade no discurso:

(1) Mais de três anos após o crime, a polícia de São Paulo prendeu o último dos quatro homens acusados de envolvimento direto no assassinato do juiz (...) José Machado Dias, ocorrido em março de 2003. Adilson Daghia, 37, (...) foi preso na última sexta-feira, em São Miguel Paulista (...) (Folha de São Paulo, 07/11/2006)

(2) Según informaron hoy fuentes policiales, esta organización tenía como objetivo la captación, introducción y distribución de mujeres de nacionalidad brasileña en diferentes clubes de la Comunidad gallega para su explotación sexual. En concreto, el modus operandi utilizado por la red empezaba cuando un 'Coyote' (...), que posteriormente fue identificado como K.A.L., (...) entraba en contacto con chicas dispuestas a venir a España a trabajar. (La Vanguardia, 29/09/2006)

- inferência textual ou extratextual:

(3) O norte-americano Lance Armstrong, aos 32 anos, consolidou de vez seu nome na história do esporte ao garantir neste domingo o hexacampeonato da Volta da França, a mais importante competição do ciclismo mundial. Representando a equipe U.S. Postal, o texano foi ovacionado ao cruzar a linha de chegada na principal avenida de Paris, a Champs-Elysées. (O Estado de São Paulo, 25/07/2004) (a referência à famosa competição francesa e a um dos seus célebres vencedores, assim como a presença do verbo ovacionar, permitem ao ouvinte/leitor recuperar o agente 
— o público, a platéia que prestigiava o evento — da construção passiva)

(4) El meta checo Cech, primera opción del entrenador portugués José Mourinho, fue operado con éxito el domingo en el hospital Radcliff de Oxford, tras sufrir un hundimiento craneal en el transcurso de ese partido. (La Vanguardia, 16/10/2006) (no enunciado anterior, o verbo operar comporta restrições semânticas que levam o ouvinte/leitor a inferir que o agente é um médico)

- desconhecimento:

(5) (...) As "escapadas" do bailarino seriam algo constante, diz o tablóide. Uma prostituta de nome Danielle Coakley, 20, afirmou à publicação que consumia drogas e fazia programa com Federline quando Britney estava grávida. O bailarino foi visto diversas vezes em Las Vegas acompanhado por mulheres. Outra stripper, Vanessa Hulihan, 30, afirmou que ele gosta muito de festas cheias de dançarinas. (Folha de São Paulo, 13/11/2006).

(6) En la localidad cisjordana de Tulkarem, una iglesia de piedra levantada hace 170 años fue incendiada antes de que amaneciera y todo el interior quedó destrozado, según informaron responsables cristianos locales. (La Vanguardia, 17/09/2006)

E o que pode ser dito sobre os casos em que o agente aparece nessas construções? Em sua proposta, Duarte (1990:163) afirma que, nas passivas com agente explícito, este aparece recodificado por um sintagma preposicional em posição de foco sentencial (passivas sintáticas: A criança foi mordida pelo cão) ou pelo clítico "se" (passivas pronominais: Vendem-se carros); a autora não especifica se esse foco está ou não relacionado com informação nova. 
Miñones (2000) conclui que a presença do agente em algumas estruturas se deve à necessidade de:

- apresentar uma entidade não mencionada no discurso, portanto, introduzir informação nova:

(7) Vinte corpos de pessoas assassinadas com tiros na cabeça foram encontrados hoje pela Polícia em diferentes regiões de Bagdá, segundo fontes do Ministério do Interior iraquiano. (Folha de São Paulo, 16/10/2006)

(8) El gerente de la agencia oficial Itar-Tass, Anatoli Voronin, fue asesinado en su domicilio, informó hoy la agencia rusa. El cadáver de Voronin, que mostraba señales de violencia, fue hallado por su chófer, quien avisó a la policía, indicaron fuentes de la Fiscalía de Moscú. (La Vanguardia, 16/10/2006)

- contrastar agentes:

(9) Rogério Andrade foi preso em setembro, pela Polícia Federal, depois de quatro anos foragido. É acusado pela morte do primo, Paulinho, e por formação de quadrilha. Menos de um mês depois, seu rival foi preso em um apartamento na Praia de São Conrado, pela Polícia Civil. (Jornal do Brasil, 5/11/2006)

(10) A.S.B., sin antecedentes penales y en libertad por esta causa, representado por la Procuradora $D^{a}$ M.E.G.G. $y$ defendido por el Letrado D. C.S.A. en sustitución de la Letrada $D^{a}$ C.M.Q. (Copia privada de carátulas de videojuegos: sentencia absolutoria [07/10/2004], em http://www.bufetalmeida.com , consultado em 08/12/2006)

- abrir uma cadeia temática (com conseqüente persistência do agente nas sentenças imediatamente posteriores à sua introdução).

(11) (...) uma ajuda financeira (...) , menos quaisquer montantes já recebidos pela vítima a título de indenização. Se, após ter 
beneficiado de ajuda, $[1]^{57}$ a vítima provar que o dano sofrido é superior àquele com base no qual a ajuda foi concedida, [2] pode solicitar uma ajuda suplementar apresentando [3] um pedido nesse sentido no prazo fixado pela citada lei. (...) (Atlas Judiciário Europeu, consultado em 08/12/2006, na página http://ec.europa.eu/justice home/judicialatlascivil)

Código de campo alterado

(12) Del tenor literal del precepto parece que en el supuesto de autos sólo podrían calificarse como copias privadas las de las carátulas efectuadas por el acusado para utilizarlas [1] en su local colocándolas [2] en sustitución del original en las cajas de los videojuegos que [3] alquila, pero no las que [4] hacía para terceros. (Copia privada de carátulas de videojuegos: sentencia absolutoria [07/10/2004], em http://www.bufetalmeida.com, consultado em 08/12/2006)

Miñones \& Sánchez (1999) apontam a tendência de o agente apresentar o traço [+humano] e grau elevado de participação voluntária na ação/processo. É provável que todas essas afirmações feitas sobre o agente no Espanhol escrito sejam válidas para o PB, conforme parecem mostrá-lo os exemplos recolhidos; entretanto, é recomendável que se faça uma análise para comprovar se de fato tais tendências se confirmam nessa língua.

\section{I.4.4. Paciente [+humano] vs. [-humano]}

Moino (1989:47) mantinha a hipótese (com base em Givón,1979) de que o SN/paciente das construções passivas deveria possuir o traço [-humano], o

\footnotetext{
${ }^{57}$ Os números entre colchetes indicam as posições nas quais o agente é retomado. Conforme se pode ver nos exemplos (11) e (12), nem sempre esse elemento está explícito; entretanto, pode-se retomá-lo por elipse. Na definição de Fávero \& Koch (1983:40), a elipse é um fator de coesão textual que consiste na omissão de um item lexical recuperável pelo contexto, ou seja, a substituição por zero (Ø).
} 
que não se verificou exatamente: na modalidade oral, $66,5 \%$ dos pacientes possui o traço [+humano]; na escrita, $88,3 \%$ apresentam o traço [-humano].

Sobre esses percentuais, a autora (ibid.: 47) faz o seguinte comentário:

\begin{abstract}
A única explicação possível que encontramos para esse tipo de resultado é relativa aos assuntos desenvolvidos em editoriais; geralmente assuntos como política, economia, etc. tratados na maior parte das vezes enquanto instituições, portanto com referente inanimado. Por outro lado, as entrevistas giram normalmente em torno da vida pessoal do informante — sua família, seu círculo de trabalho, etc. — ou seja, assuntos que propiciam o aparecimento de referentes humanos.
\end{abstract}

No que diz respeito ao discurso escrito, relativizo as afirmações da autora acerca das razões para a maior incidência de pacientes [-humano] no gênero editorial, por considerar que a classificação dessas entidades depende da interpretação do pesquisador. Tomemos os seguintes exemplos:

(13) A escola foi construida em zona privilegiada, próxima ao metrô. Está equipada com modernos dispositivos de segurança, possui ginásio de esportes, piscina e laboratório de informática.

(14) A escola foi acusada de praticar discriminação racial, porém não se pronunciou sobre o fato.

Em (13), o referente escola aparece relacionado a aspectos como localização geográfica e instalações físicas; portanto, não haveria dificuldade em considerá-lo como [-humano]. Em (14), ao contrário, escola designa um organismo ativo, um coletivo profissional que desempenha funções e presta serviços; dessa forma, considero mais adequado classificá-lo como [+humano]. Além disso, considerando-se a modalidade escrita, os resultados poderiam ser diferentes caso o gênero escolhido fosse outro, por exemplo, a notícia policial: provavelmente haveria freqüência considerável de pacientes [+humano] e a distribuição seria mais harmônica. $\mathrm{Na}$ modalidade oral, igualmente, poderíamos ter distintos gêneros de entrevista (por exemplo, entrevistas para seleção profissional, enquetes, coletivas, etc.), e com diferentes graus de formalidade. Portanto, por razões de confiabilidade, só um corpus diversificado (de entrevistas, no caso) poderia confirmar ou não a tendência das passivas a apresentar pacientes [+humano] ou [-humano]. 
Na análise das passivas sintáticas feita por Miñones \& Sánchez (1999) , o Paciente é majoritariamente [-humano], em percentuais variáveis conforme o gênero discursivo ${ }^{58}$. Barbeito \& Miñones (2002), em seu trabalho sobre as passivas pronominais, constataram a supremacia do traço [-humano] para o Paciente, cujo porcentagem atingiu 95\% do total observado.

Em todas as análises que consultei - tanto para o PB quanto para o Espanhol - , verificou-se a tendência das passivas a apresentar pacientes com traço [-humano]. É essa a hipótese que assumo, baseada unicamente nos resultados desses estudos.

\section{I.4.5. Caráter temático/ remático do paciente}

Duarte (ibid.) contabilizou $89,6 \%$ de SN/pacientes em posição temática. A hipótese inicial de Moino (ibid.), ao contrário, era de que o SN/paciente tivesse natureza remática, ou seja, que veiculasse informação [+nova]. Sua expectativa, porém, não se confirmou: na modalidade oral foi alta a freqüência de SN/pacientes evocados ou inferíveis, chegando a $78,7 \%$ nas passivas sintáticas; na modalidade escrita os resultados foram similares para as sintáticas, porém com menor índice de SN/pacientes temáticos $(44,8 \%)$ nas lexicais. A autora conclui, portanto, que no PB a passiva não é uma estrutura marcada no que diz respeito à distribuição de informação: não se tem sempre informação [+conhecida] precedendo a $[+n o v a]^{59}$. Aqui cabe um comentário: no nosso entender, a alta incidência de pacientes com traço [+conhecida] para as passivas sintáticas é natural, uma vez que nessas construções o paciente se encontra em posição temática normalmente vinculada à informação dada. No caso das passivas pronominais do $\mathrm{PB}$, infelizmente não tive acesso a

\footnotetext{
${ }^{58}$ No conto infantil há mais pacientes [-humano]; no texto histórico, a maioria deles é [+humano].

${ }^{59}$ Em seu estudo, Moino não detalha se o traço [+conhecida] é relativo à informação já mencionada no discurso ou a uma referência extratextual. Da mesma forma, não especifica se o traço [+nova] refere-se à informação veiculada no discurso pela primeira vez ou se é referente a uma entidade já mencionada e que aparece em nova função.
} 
estudos referentes ao estatuto pragmático do paciente (se é predominantemente de natureza temática ou remática).

A hipótese de Miñones \& Sánchez (1999) era de que o SN/paciente nas passivas sintáticas:

a) aparecesse à esquerda da sentença, desempenhando as funções de tema ( e portanto, dotado do traço [+conhecida] ) e sujeito. Vejamos exemplos do PB e do Espanhol (também citados nos itens subseqüentes):

(15) A Biblioteca do IEL convida a todos para visitar a exposição em comemoração ao centenário do Nascimento de Quintana! Estão expostas obras de Primeira Edição, Crítica Literária, Infanto-Juvenil, Tradução e uma obra autografada pelo próprio autor, em destaque. A Exposição foi inaugurada no dia 10/08/2006 e se entenderá até o início do mês de outubro. (http://www.iel.unicamp.br/portal/biblioteca/noticias.html, 18/11/2006)

Michael Jackson ha sido galardonado con el premio Diamond, por su más de cien millones de discos vendidos. El premio fue otorgado durante un certamen dedicado a la Música del Mundo celebrado en Londres.

(http://www.hispamp3.com/noticias/noticia.php?noticia=20061116134334 , 03/12/2006)

Em contraposição às características predominantes encontradas para o agente (ver seção 1.4.3.), a maioria dos pacientes catalogados por Miñones \& Sánchez (ibid.) apresentam alto grau de afetação e alto grau de participação não voluntária no processo.

b) apresentasse baixa distância referencial à esquerda (ou seja, deveria existir um SN correferente ao paciente em ao menos uma das três sentenças anteriores à passiva), conforme os exemplos:

(17) Em 1981, dirigiu PIXOTE, A LEI DO MAIS FRACO, sobre as crianças abandonadas do Brasil. Graças à interpretação inesquecível de Fernando Ramos da Silva (10 anos na época 
do filme; assassinado pela polícia em 1987), (...) o filme foi um sucesso mundial e recebeu vários prêmios internacionais. Pela Associação dos Críticos de Los Angeles e Nova York, foi considerado o melhor filme estrangeiro (1981)

(http://www2.uol.com.br/hectorbabenco/diretor/htm , 14/10/2006)

(18) (recolhido pelas autoras) (...) Las fuerzas armadas terminaron Código de campo alterado de consolidarse como poder político. Los militares habían buscado la cobertura civil. Ahora, mientras las tropas marchaban hacia la Plaza de Mayo, y eran, otra vez, aplaudidas por la población cansada del fraude y la corrupción (...) [LRP] )

c) mantivesse persistência temática à direita (ou seja, o paciente deveria ser mencionado nas três sentenças imediatamente posteriores à sentença passiva), conforme os exemplos:

(19) Marinaldo Fernando da Silva, 19 anos, foi assassinado durante um assalto quando retornava da aula, por volta das 23h. Dois assaltantes o abordaram na rua Mirimitisson, a alguns metros de sua residência. Marinaldo reagiu ao roubo e $\varnothing$ foi executado com um tiro na cabeça. (Diário do Pará, 06/12/2006).

(20)_Un juzgado de San Sebastián mantiene abierta una investigación sobre un hombre que fue detenido por la Guardia Municipal donostiarra $\varnothing$ acusado de un delito de corrupción de menores. Según fuentes jurídicas y de la Fiscalía, el imputado realizó fotografías de menores desnudos. Varias de estas imágenes Ø las llevaba en su teléfono móvil. Asimismo, Ø habría realizado diversos tocamientos a los chicos. El procedimiento en el que el inculpado se halla inmerso está siendo investigado en la actualidad por el Juzgado de Instrucción 4 de la capital guipuzcoana. El acusado fue detenido hace unos meses por la Guardia Municipal de San Sebastián cuando $\varnothing$ se disponía a establecer un contacto con un chaval de 14 años. (Diario Vasco, 29/11/2006) 
De acordo com as autoras, a análise permitiu verificar (a) plenamente, e (b) parcialmente. Quanto a (c), os resultados não foram os esperados para o corpus constituído, uma vez que a persistência do paciente como tema se observa em apenas uma ou duas sentenças após a passiva.

A análise de Barbeito \& Miñones (2002) para as passivas pronominais revelou que a maioria dos $\mathrm{SN} /$ pacientes é remática $(78,3 \%)$, veicula informação com traço [+nova] $(74,7 \%)$ e está focalizada $(74,7 \%)$ :

(21) La Cámara ordenó que se busquen pruebas para determinar si la* Formatados: Marcadores e jueza Servini de Cubría estuvo presente en una reunión en la que el titular de la Secretaría de Inteligencia del Estado habría pedido la detención de Carlos Rohm. (Clarín, 25/5/02)

(22) En poder de los detenidos se secuestró un revólver calibre 32 con numeración limada (...) (Clarín, 13/4/02).

\section{l.4.6. Função das construções passivas}

Duarte (1990:163) propõe como função básica das passivas ${ }^{60}$ no PB a detematização do agente. Essa detematização inclui tanto a supressão do agente (caso predominante), como sua recodificação na sentença por um sintagma preposicional em posição remática (passivas sintáticas) ou através do clítico se (passivas pronominais). Como função decorrente (e portanto secundária) da detematização do agente, a autora aponta a tematização, que define como a promoção de um constituinte para a posição inicial, temática (geralmente o promovido é um paciente). É preciso deixar claro, porém, que a tematização nem sempre se dá através das passivas: há outros recursos, como o alçamento do objeto direto numa sentença ativa, que consiste em deslocar

\footnotetext{
${ }^{60}$ Na conclusão do seu estudo, Duarte (ibid.: 164) afirma que a detematização do agente é, em realidade, a função universal das passivas e, por isso mesmo, válida para todas as línguas. A autora apóia-se em evidências translingüísticas, dando exemplos de enunciados no PB, Inglês, Turco, Indonésio, Ute, entre outras.
} 
esse complemento para a esquerda da sentença e retomá-lo por um pronome| "cópia” (apud Pontes, 1987:65):

(23) Esse encanto pelo Rio, eu o encontro em cada bairro que morei. (Pedro Nava, apud Pontes, 1987:57)

(24) A ese alumno lo elogiaron todos los profesores. (Fanjul, 1999: 149)

No PB, enunciados como (23) estão restritos ao registro formal (oral e escrito). No registro coloquial, como demonstram diferentes estudos, os clíticos acusativos desaparecem ou são substituídos por pronomes tônicos ( 0 carro, eu levei $\varnothing$ pro mecânico ontem/ 0 carro eu levei ele pro mecânico ontem). No PB, a perda dos clíticos tem como conseqüência a perda da possibilidade de tematizar através do deslocamento à esquerda; daí, possivelmente, uma maior incidência da passiva sintática nos processos de

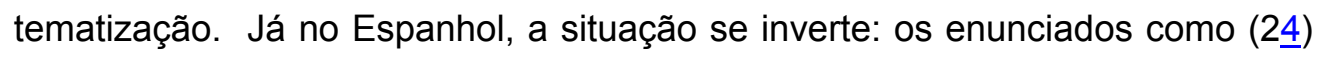
são muito freqüentes em qualquer registro dessa língua, na qual a tematização por deslocamento à esquerda e duplicação por clítico parece ser a regra.

Para o Espanhol, os trabalhos consultados não propõem uma função básica para as passivas como um todo: Miñones \& Sánchez (1999) postulam a tematização do paciente nas passivas sintáticas; Barbeito \& Miñones (2002) apontam a focalização do paciente (veiculador de informação nova) nas passivas pronominais. Entretanto, assim como no PB, no Espanhol ocorre ausência majoritária do agente ou sua recodificação nos termos especificados por Duarte (ver I.3., p.40); com base nesses dados, podemos assumir que também no Espanhol a função básica das passivas é a detematização do agente.

\section{I.4.7. Considerações finais}

Na primeira parte deste capítulo, apoiando-me em diversos estudos sobre as passivas no PB e no Espanhol, busquei mostrar que o repertório dessas 
construções nas duas línguas vai além das formas canônicas (ser/ser + particípio [perifrástica]; se/se $+3^{a}$ pessoa [pronominal]) normalmente apresentadas na maioria das gramáticas e livros didáticos: esse leque inclui construções perifrásticas com auxiliares distintos de "ser"/ser, passivas lexicais, construções de particípio absoluto, construções de infinitivo, impersonales activas, nominalizações, entre outras. A partir do capítulo subseqüente, para referir-me a esse conjunto, adoto o termo formas com valor passivo ${ }^{61}$. A expressão "valor" deve ser entendida segundo a formulação de Saussure. Afirma o lingüista (1970:134-135):

No interior de uma mesma língua, todas as palavras que exprimem idéias vizinhas se limitam reciprocamente: sinônimos como recear, temer, ter medo só têm valor próprio pela oposição; se recear não existisse, todo seu conteúdo iria para os seus concorrentes.

Mais adiante, Saussure (ibid.:135) estende o que disse para as palavras a qualquer termo da língua. Pensando no conceito de valor lingüístico aplicado às construções passivas, poderíamos afirmar, por exemplo, que a passiva com "ser" (a porta foi aberta) tem um valor dinâmico que só se estabelece por oposição à passiva estativa, com "estar" (a porta está aberta), e vice-versa. Igualmente, diríamos que a passiva com os auxiliares resultar ou salir (diez alumnos resultaron/ salieron heridos) só adquire um valor resultativo (com ênfase no resultado) se oposta a outras que focalizem a ação ainda em transcurso, como é o caso da passiva com ir (van rescatados cinco heridos).

O termo formas com valor passivo, portanto, permite-nos reunir na mesma expressão tanto a diversidade de formas lingüísticas referentes às passivas, quanto os diferentes valores que assumem essas formas, resultantes das oposições que guardam entre si.

$\mathrm{Na}$ segunda parte do capítulo, contrasto as passivas no PB e no Espanhol, na modalidade escrita, chegando à seguinte síntese:

1.O PB e O Espanhol apresentam preferências distintas: no PB predominam as passivas de particípio (sintáticas e lexicais), enquanto no Espanhol as passivas pronominais são mais abundantes.

2.O PB e o Espanhol tendem a omitir o agente nas construções passivas.

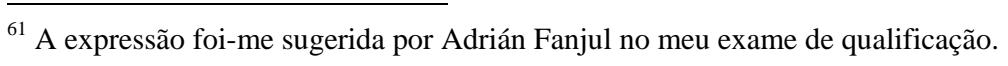


3. No PB e no Espanhol a tendência é que incidam pacientes com traço semântico [-humano].

4.O PB e o Espanhol tendem a tematizar o paciente nas passivas de particípio (sintáticas e lexicais); nas passivas pronominais do Espanhol a maioria dos pacientes é remática, veicula informação com traço [+nova] e está focalizada.

5.A função básica das passivas no PB e no Espanhol é a detematização do agente. Como função secundária nas passivas de particípio, podemos apontar a tematização do paciente. Nas passivas pronominais do Espanhol (não temos dados do PB), pode-se apontar como função secundária a focalização do paciente e a veiculação de informação nova (rema).

Com base nessas afirmações, no capítulo seguinte analiso a produção de passivas em Espanhol, no discurso escrito, por aprendizes brasileiros de E/LE. Porém, reitero a necessidade de se fazerem novas análises para as duas línguas, com atenção especial na constituição do corpus. Um corpus variado, no qual os mais diversos gêneros discursivos sejam contemplados e que possibilite, inclusive, uma análise de freqüência por gêneros, se o pesquisador assim o quiser — , terá maiores condições de oferecer respostas mais precisas às questões levantadas. 


\section{CAPÍTULO II}

Os corpora

Trabalhei com dois corpora de aprendizes. O primeiro deles, que denominarei Corpus preliminar, compõe-se de uma pequena amostra de textos escritos por meus alunos de E/LE no EEC; utilizei-o no intuito de fazer uma primeira análise de como as formas com valor passivo ${ }^{62}$ apareciam e se comportavam na produção escrita desses estudantes. O segundo corpus é o Dados EEC, construído pelo Grupo de Aquisição do EEC também a partir de textos escritos por alunos desse curso.

\section{II.1. Corpus preliminar}

Os dados desse corpus (doravante $\mathrm{C} 1$ ) foram extraídos de produções escritas de aprendizes brasileiros de E/LE, todos eles meus alunos no EEC entre agosto de 2002 e junho de 2004. Optei por trabalhar com aprendizes que já tivessem sido expostos às principais estruturas morfossintáticas do Espanhol (maior parte do sistema verbal, sistema pronominal, concordância, regência, colocação, uso de alguns marcadores discursivos, entre outros); portanto, considerando a estrutura pedagógica do EEC, meus informantes eram alunos com mais de 130 horas de instrução formal em E/LE. Essa decisão me permitiu selecionar produções com maior complexidade na elaboração lingüística e, igualmente, constituir um corpus diversificado com relação aos gêneros do discurso.

As produções surgiram atreladas ao processo de avaliação escrita que costumamos adotar no EEC, ou seja, provas e trabalhos. As condições de produção foram distintas num caso e noutro: as provas eram feitas na sala de aula, sem consulta; os trabalhos eram feitos em casa, com a possibilidade de consultar livros didáticos, livros de referência e outras fontes. Esses textos não

\footnotetext{
${ }^{62}$ Para a explicação desse conceito, ver item I.4.7. Doravante, a expressão aparecerá como FVP
} 
foram produzidos de forma monitorada no que diz respeito ao objetivo específico da minha pesquisa (as FVP), o que os exime de certo grau de artificialismo muitas vezes presente quando se força ou se condiciona o aparecimento de determinada estrutura no corpus. Acerca dos gêneros presentes nos dois corpora, convém esclarecer que não são autênticos, mas sim projeções: não se trata, por exemplo, de jornalistas redatando editoriais, crônicas, críticas ou notícias para um público leitor; o que se tem é o exercício da escrita em língua estrangeira (no caso, em Espanhol) feito por alunos, mediante instrução formal e tendo como único destinatário o professor. Portanto, embora se tenha buscado a diversidade nas práticas textuais pedidas aos alunos, buscando aproximá-las dos gêneros correntes no cotidiano, essas produções são inevitavelmente atravessadas pela prática pedagógica.

Sobre os gêneros exercitados, os aprendizes:

a) construíram uma narrativa a partir de imagens dispostas em ordem não cronológica (Anexo 01);

b) escreveram uma carta formal para queixar-se da baixa qualidade dos serviços oferecidos por um hotel (Anexo 02);

c) estabeleceram comparações entre duas profissões (Anexo 03);

d) responderam questões de interpretação de texto (Anexo 04);

e) no papel de empregado, construíram um diálogo com um chefe hipotético, justificando por que não deveriam ser demitidos (Anexo 05);

f) redigiram a resenha crítica de um filme exibido no curso (Anexo 06).

Esclareço que, nessa coleta, todas as ocorrências foram mantidas em seus contextos, de maneira a possibilitar maior consistência na etapa de análise. Os exemplos citados no trabalho também foram transcritos tal qual aparecem nas produções, sem qualquer correção.

Examinei um total de 71 produções escritas, e dessa amostra levantei 72 incidências de construções passivas (ver CORPORA, Corpus C1, p. 151).

A tabela 1 sintetiza os dados referentes aos informantes: 


\begin{tabular}{|c|c|c|}
\hline GRUPOS & $\begin{array}{c}\text { HORAS-AULA } \\
\text { (faixa) }\end{array}$ & ALUNOS \\
\hline I & 135 a 180 & 37 \\
\hline II & 180 a 225 & 08 \\
\hline III & 225 a 270 & 26 \\
\hline
\end{tabular}

Tab. 1: Informantes (C1)

\section{2. Dados EEC}

Este corpus de aprendizes está sendo construído pelo Grupo de Aquisição, como parte das atividades de pesquisa do $E E C^{63}$ e sob a coordenação deste pesquisador desde 2003. Na etapa inicial - março a junho de 2003 - , definiu-se uma metodologia para o cadastramento de informantes, a produção e a coleta de dados; essa metodologia foi posta em prática em agosto de 2003, quando passou-se a acompanhar um grupo de voluntários do primeiro ao último estágio do $\mathrm{EEC}^{64}$, de maneira a dispor de dados longitudinais e transversais que pudessem revelar aspectos da aquisição/aprendizagem desses informantes em vários momentos do processo.

\section{II.2.1. Os informantes}

O cadastramento inicial de informantes ${ }^{65}$ foi feito em agosto de 2003 e o último em janeiro de 2005; a coleta de produções, porém, prosseguiu até junho

\footnotetext{
${ }^{63}$ Integrei o referido grupo de agosto de 2002 (quando surgiu) até dezembro de 2006. A proposta de criação de um banco de dados para a produção escrita dos alunos do EEC surgiu com as primeiras discussões do grupo, a partir da leitura de textos teóricos sobre aquisição de línguas estrangeiras. Mais especificamente, formulamos a proposta com base nos comentários de Marta Baralo (1999:37-44.) acerca de trabalhos de Graciela Vázquez e Sonsoles Fernández em Análise de Erros, nos quais essas pesquisadoras constituíram corpora para analisar a interlíngua de estudantes estrangeiros aprendizes de Espanhol.

${ }^{64}$ Na ocasião, a grade completa do curso compreendia os níveis Básico I, Básico II, Intermediário I, Intermediário II, Avançado I e Avançado II.

${ }^{65}$ A inscrição dos colaboradores foi voluntária, através do preenchimento de uma FICHA DE ACOMPANHAMENTO (Anexo 07) e de um TERMO DE AUTORIZAÇÃO (Anexo 08) do uso de suas
} 
de 2006, quando o grupo inicial concluiu o curso. Portanto, a coleta durou três anos e, simultaneamente, desenvolveu-se um programa ${ }^{66}$ para organizar e acessar os dados recolhidos.

O corpus (doravante $\mathrm{C} 2$ ) tem 186 informantes cadastrados, dos quais a maior parte $(73 \%)$ é do sexo feminino. A tabela 2 detalha os percentuais referentes ao sexo. No que diz respeito à idade (tabela 3 ), a maioria dos informantes $(37,63 \%)$ pertence à faixa etária compreendida entre os 20 e 30 anos, seguida do grupo que está entre 30 e 40 anos (23,12\%); o grupo de terceira idade (acima de 60 anos) corresponde a 4,84\% do total (09 informantes).

\begin{tabular}{|l|c|c|}
\hline INFORMANTES & QUANTIDADE & $\%$ \\
\hline Homens & 50 & 27 \\
\hline Mulheres & 136 & 73 \\
\hline \multicolumn{1}{|c|}{ TOTAL } & 186 & 100 \\
\hline
\end{tabular}

Tab. 2: Informantes por sexo (C2)

\begin{tabular}{|l|c|c|}
\hline \multicolumn{1}{|c|}{ FAIXA ETÁRIA } & QUANTIDADE & $\%$ \\
\hline Até 20 anos & 24 & 12,90 \\
\hline 20 a 30 anos & 70 & 37,63 \\
\hline 30 a 40 anos & 43 & 23,12 \\
\hline 40 a 50 anos & 28 & 15,05 \\
\hline 50 a 60 anos & 10 & 5,38 \\
\hline Acima de 60 anos & 9 & 4,84 \\
\hline Não informaram & 2 & 1,08 \\
\hline \multicolumn{1}{|c|}{ TOTAL } & 186 & 100 \\
\hline
\end{tabular}

Tab. 3: Informantes por idade (C2)

produções para compor o corpus. A ficha nos dá o perfil do aluno, incluindo dados pessoais (idade, sexo, nível de instrução, profissão) e informações relacionadas à aprendizagem de línguas estrangeiras (contato prévio com línguas estrangeiras, onde as estudou, como avalia seu desempenho no processo, suas expectativas e interesses relacionados ao aprendizado do Espanhol, imagem que tem dessa língua). Cada informante recebeu um código alfanumérico ao inscrever-se, de modo a manter-se em sigilo sua identidade e ser possível a identificação posterior de suas produções.

${ }^{66}$ O programa foi desenvolvido no aplicativo Microsoft Access (versão 2002) e disponibiliza um menu de pesquisa por informantes (sexo, faixa etária, contato com outras línguas) e por produções (níveis básico, intermediário e avançado); também oferece a opção de imprimir relatórios (fichas cadastrais e produções dos informantes). 
Quanto à escolaridade, $94,6 \%$ do total de informantes chegou à universidade. Esse percentual nos dá idéia do perfil do aluno médio do EEC: este, em geral, pertence à comunidade USP — é estudante (graduando, pósgraduando), professor ou funcionário da instituição. Do total, apenas $4 \%$ afirmam ter tido algum tipo de contato com a língua espanhola antes de matricular-se no $\mathrm{EEC}^{67}$.

\section{II.2.2. As produções}

Para que C2 fosse o mais diversificado possível, foram solicitadas aos informantes produções escritas associadas a distintos gêneros discursivos: anúncios pessoais, anúncios publicitários, cartas formais e informais, diários, resenhas, crônicas, artigos de opinião, sínteses, críticas de filmes, etc. Em parte das produções (os trabalhos escritos, feitos em casa), os informantes tiveram total liberdade de consulta a livros didáticos, livros de referência e outras fontes; a parte restante compõe-se das redações pedidas nas provas escritas do curso (parcial e final), portanto feitas sem consulta. Na tabela 4 disponibilizo essas informações.

A elaboração dessas atividades foi feita em função do programa de cada estágio (principalmente aqueles iniciais). No caso do Básico I, por exemplo, considerando o vocabulário restrito e as poucas estruturas às quais o aprendiz foi exposto, trabalhamos com gêneros mais simples, mais descritivos, como os anúncios pessoais. À medida que o aprendiz avançava, outros gêneros eram incorporados: carta informal, diário de viagem, anúncios publicitários, notícia de jornal, entrevista, crônica, carta formal, etc.

As produções foram digitalizadas em formato. $\mathrm{txt}^{68}$, de modo a poder ser processadas convenientemente por programas de análise de dados (como o WordSmith Tools).

\footnotetext{
${ }^{67} \mathrm{O}$ cadastramento de todos os informantes ocorreu quando ingressaram no primeiro nível do EEC (Básico I).

${ }^{68}$ É preciso explicar que esse formato é de texto puro, sem elementos de formatação (negritos, itálicos, variações de cor) que fazem parte de editores como o Word , por exemplo. O formato .txt, além de ocupar
} 


\begin{tabular}{|c|c|c|c|c|}
\hline \multirow[t]{2}{*}{ NÍVEL } & \multirow[t]{2}{*}{ HORAS-AULA } & \multicolumn{2}{|c|}{ PRODUÇÕES ESCRITAS } & \multirow{2}{*}{$\begin{array}{l}\text { TOTAL POR } \\
\text { INFORMANTE }\end{array}$} \\
\hline & & TRABALHOS & PROVAS & \\
\hline $\begin{array}{c}\text { Básico I [B1] } \\
(\text { Anexos 09, 10, 11, 12) }\end{array}$ & 0 a 45 & 02 & 02 & 04 \\
\hline $\begin{array}{c}\text { Básico II [B2] } \\
(\text { Anexos 13, 14, 15, 16) }\end{array}$ & 45 a 90 & 02 & 02 & 04 \\
\hline $\begin{array}{l}\text { Intermediário I [I1] } \\
(\text { Anexos 17, 18, 19, 20) }\end{array}$ & 90 a 135 & 02 & 02 & 04 \\
\hline $\begin{array}{c}\text { Intermediário II [I2] } \\
\text { (Anexos 21, 22, 23, 24, 25) }\end{array}$ & 135 a 180 & 03 & 02 & 05 \\
\hline $\begin{array}{c}\text { Avançado I [A1] } \\
\text { (Anexos 26, 27, 28, 29, 30) }\end{array}$ & 180 a 225 & 03 & 02 & 05 \\
\hline $\begin{array}{c}\text { Avançado II [A2] } \\
\text { (Anexos 31, 32, 33, 34, 35) }\end{array}$ & 225 a 270 & 03 & 02 & 05 \\
\hline
\end{tabular}

Tab. 4: Produções coletadas por nível (C2)

O código das produções segue padrão proposto pelo $\mathrm{COMET}^{69}$ e é alfanumérico, com 8 dígitos (limitação do DOS): o primeiro indica a procedência do aluno (a língua que estuda e se o faz na graduação ou em curso extracurricular - ver tabela 5); o segundo, o ano e semestre da produção (ver tabela 6); o terceiro, o estágio em que se encontra (ver tabela 7); os quatro seguintes, o número do informante (que é fixo e depende da seqüência de cadastro: caso o informante abandone temporariamente o curso, quando voltar manterá o mesmo número); e o último, o número da produção (pode ir de 1 a 5 , em nosso caso).

\begin{tabular}{|l|l|l|}
\hline \multirow{2}{*}{ ALEMÃO } & Campus & $\mathrm{A}$ \\
\cline { 2 - 3 } & Graduação & $\mathrm{L}$ \\
\hline \multirow{2}{*}{ ESPANHOL } & Campus & $\mathrm{E}$ \\
\cline { 2 - 3 } & Graduação & $\mathrm{S}$ \\
\hline \multirow{2}{*}{ FRANCÊS } & Campus & $\mathrm{F}$ \\
\cline { 2 - 3 } & Graduação & $\mathrm{R}$ \\
\hline \multirow{2}{*}{ INGLÊS } & Campus & $\mathrm{I}$ \\
\cline { 2 - 3 } & Graduação & $\mathrm{N}$ \\
\hline \multirow{2}{*}{ ITALIANO } & Campus & $\mathrm{T}$ \\
\cline { 2 - 3 } & Graduação & $\mathrm{O}$ \\
\hline
\end{tabular}

\begin{tabular}{|c|c|}
\hline Letra & Ano/Semestre \\
\hline A & $2003 / 2$ \\
\hline B & $2004 / 1$ \\
\hline C & $2004 / 2$ \\
\hline D & $2005 / 1$ \\
\hline E & $2005 / 2$ \\
\hline F & $2006 / 1$ \\
\hline \multicolumn{2}{c}{ Tab. 6}
\end{tabular}

\begin{tabular}{|c|l|}
\hline$N^{\circ}$ & Curso/ Nível \\
\hline 1 & Básico 1 \\
\hline 2 & Básico 2 \\
\hline 3 & Intermediário 1 \\
\hline 4 & Intermediário 2 \\
\hline 5 & Avançado 1 \\
\hline 6 & Avançado 2 \\
\hline
\end{tabular}

Tab. 7

menos memória, não necessita que se perca tempo "limpando" caracteres indesejáveis quando submetidos os arquivos a um programa de análise de dados.

${ }^{69}$ Corpus Multilíngüe para Ensino e Tradução, desenvolvido pelo Centro Interdepartamental de Tradução e Terminologia (CITRAT), da FFLCH/USP. 
Por exemplo, a quarta produção de um aluno do EEC, de código 95, cursando o Básico 2 no segundo semestre de 2004, seria codificada como EC200954.txt.

Para os níveis $\mathrm{B} 1, \mathrm{~B} 2$ e 11 , os dígitos finais 3 e 4 representam as produções realizadas na sala de aula (provas escritas). No caso dos níveis I2, $\mathrm{A} 1$ e $\mathrm{A} 2$, as produções correspondentes às atividades na sala de aula são aquelas com dígitos finais 4 e 5 .

A quantificação das produções (por nível) com as quais trabalhei está na tabela 8.

\begin{tabular}{|c|c|c|c|}
\hline NIIVEL & QUANTIDADE & $\%$ & $N^{\circ}$ PALAVRAS \\
\hline B1 & 545 & 46,5 & 62.376 \\
\hline B2 & 251 & 21,4 & 47.627 \\
\hline I1 & 147 & 12,5 & 22.514 \\
\hline I2 & 121 & 10,3 & 20.268 \\
\hline A1 & 60 & 5,1 & 14.420 \\
\hline A2 & 48 & 4,1 & 10.861 \\
\hline TOTAL & 1.172 & 100 & 178.066 \\
\hline
\end{tabular}

Tab. 8: Total de produções analisadas (C2)

\section{II.3. Levantamento das FVP nos corpora}

Para o corpus $\mathrm{C} 1$, constituído de apenas 71 produções em papel (manuscritas ou impressas), o levantamento das FVP foi feito manualmente e conforme a seqüência: 1) leitura do texto; 2) identificação das estruturas desejadas; 3) classificação dessas estruturas; 4) repetição dos passos anteriores para os demais textos do corpus; 5) tabulação dos padrões observados e suas freqüências.

No caso do corpus C2, com 1.172 produções digitalizadas, recorri ao programa WordSmith Tools $^{70}$ para facilitar a descrição lingüística do corpus e, assim, possibilitar-me mais informações em menos tempo. Dividi C2 em 6 subcorpora, correspondentes aos níveis do EEC - B1, B2, I1, I2, A1 e A2 - ,

\footnotetext{
${ }^{70}$ Este programa foi escrito por Mike Scott e publicado pela Oxford University. Coloca à disposição do analista uma série de recursos que, bem usados, são extremamente úteis e poderosos na análise de vários aspectos da linguagem (lexicais, morfossintáticos, discursivos, etc.) (Berber Sardinha, 2004: 86). Neste trabalho utilizei a versão 3.0 do programa.
} 
e apliquei a cada um deles as ferramentas WordList e Concord, ambas do WordSmith Tools.

Cada vez que o WordList é acionado, três janelas são produzidas na tela do computador: uma contendo uma lista de palavras em ordem alfabética (A), outra com uma lista classificada pela freqüência das palavras $(F)$, e a terceira consta de estatísticas acerca dos dados (S). Dessa última janela, utilizei apenas as informações estatísticas relevantes para a pesquisa: o número de itens do corpus (tokens) ${ }^{71}$ e o número de sentenças.

A ferramenta Concord gera concordâncias ou listagens de ocorrências de um item específico, denominado palavra de busca ou nódulo. O nódulo pode ser constituído de uma ou mais palavras e, nas concordâncias, aparece acompanhado do texto ao seu redor (cotexto). Dentre os vários tipos de concordância possíveis, a mais comum é a $\mathrm{KWIC}^{72}$, na qual a palavra de busca aparece no centro e ladeada por porções contínuas do texto original (ver fig. 1).

Gerei as concordâncias a partir de lematizações ${ }^{73}$ que abrangessem os particípios regulares e irregulares existentes em C2. No caso dos particípios regulares, usei os lemas *DO, *DOS, *DA e *DAS e obtive concordâncias para formas como llamado, detenido, escondidos, admirada, decoradas, etc. Em se tratando dos particípios irregulares, trabalhei com os seguintes lemas:

a) ${ }^{*} \mathrm{CHO},{ }^{*} \mathrm{CHOS},{ }^{*} \mathrm{CHA}$ e *CHAS para os verbos hacer, decir, etc;

b) ${ }^{*} \mathrm{TO},{ }^{*} \mathrm{TOS},{ }^{*} \mathrm{TA}$ e ${ }^{*} \mathrm{TAS}$ para os verbos fritar, resolver, escribir, inscribir, romper, volver, poner, abrir, ver, cubrir, etc.

\footnotetext{
${ }^{71}$ Além do número de itens (tokens), o programa também fornece o número de formas (types). Para que fique clara a diferença entre número de itens e número de formas, recorro a um exemplo: a sentença Joguei fora os jornais e os livros velhos possui 8 itens (joguei, fora, os, jornais, e, os, livros, velhos) e 7 formas (joguei, fora, os, jornais, e, livros, velhos). A razão forma/item (ou Type-Token Ratio) é expressa em porcentagem e indica a riqueza lexical do texto: quanto maior o seu valor, mais palavras diferentes o texto conterá; um valor baixo, em contrapartida, indica que muitas palavras se repetem, o que é indício de um texto menos rico do ponto de vista de seu vocabulário. No caso dos subcorpora de C2, a razão forma/item vai crescendo (em média), como é esperado, a medida que os aprendizes vão do primeiro ao último nível do curso. Para B1, B2, I1, I2, A1 e A2 tem-se, respectivamente, as seguintes razões forma/item (Type/Token Ratio): 10,48; 13,81; 18,90; 19,81; 21,12 e 23,22.

${ }^{72}$ Sigla de Key Word in Context, ou palavra-chave no contexto. Aqui prefiro seguir a terminologia adotada por Berber Sardinha (2004: 106) e usar o termo palavra de busca em vez de palavra-chave, já que este possui um sentido especializado no WordSmith Tools, relacionado à ferramenta KeyWords.

${ }^{73}$ Lematização é um procedimento que permite usar como palavra de busca todos os itens com um lema comum. Por exemplo, caso o analista use o lema cant* (cant seguido de asterisco) como palavra de busca, as concordâncias produzidas terão como nódulo formas como cantei, cantavam, cantariam, cantando, cantássemos, cantor, cantores, canto, cântico, etc.
} 


\begin{tabular}{|c|c|}
\hline Concordance & Set Tag Word No. \\
\hline 1 das! Así que la pena a que este hombre fue condenado no ha despertado tanta furia co & 61 ee500023.txt \\
\hline 2 aun entero la arma, para que nada feuese encontrado, pero una vecina, que no quer id & 107 ee500743.txt 5 \\
\hline 3 si hay arrepentimiento, el pecador debe ser perdonado En segundo lugar, la actitud pa & 130 lef501083.txt \\
\hline 4 que desapareció. Así que Juan Gomes fue sorprendido con la prisión no solo negó el h & 148 lef501223.txt 3 \\
\hline 5 ucho sobre esto. - Claro que sí. Esto será llevadoen cuenta. Te telefono manana. Me & 204 ee500702.txt $\varepsilon$ \\
\hline 6 ún señal de arrepentimientosolo puede ser considerado un monstruo, ¡no hay dudas! A & 46 ee500023.txt \\
\hline 7 es lo mayor don de Dios y que debe ser preservadoal cualquiér preservadoal cualq & 421 ee500703.txt \\
\hline $8 \quad$ ¿Qué remedio? El 29 de Junio será ejecutado el peligroso asesino Juan Pablo & 7 lef501123.txt \\
\hline 9 ntar, porque acertar es algo que jamás está garantizado a lo largo de nuestras vidas. & 149 ee500674.txt \\
\hline 10 Entonces ese crimen solamente podria ser considerado un infanticidio, aqui en Brasil, & 89 ee500403.txt 4 \\
\hline 11 adas y Juan Gomes está muy cerca de ser condenadoa la muerte y como parece no $\mathrm{h}$ & 236 lef501223.txt \\
\hline 12. Como si eso fuera posible. El bote estaba sellado, no hay como entrar una mosca en & 304 lef501131.txt 5 \\
\hline 13 de los derechos humanos y piden que sea hospitalizado en el manicomio de la cárcel. & 178 lef501123.txt 4 \\
\hline 14 s. JoaquínSanches, infanticida confeso, fue condenadoa muerte. Nada más justo, diría & 19 lef501153.txt \\
\hline 15 licía y los médicos. Luego de eso, Juan fue juzgado y condenadoa la penalidad máxim & 130 lef501123.txt 3 \\
\hline 16 cogí el de fresas, mi favorito. El bote estaba cerrado, con el lacre de la empresa, donde & 112 ee500021.txt 2 \\
\hline 17 ibo para comunicar el ocurrido y no para ser compensado por ello. No sé si hay algún m & 363 ee500021.txt $\varepsilon$ \\
\hline 18 persona que practica la violencia)debe ser punido - por esa violencia-, ¿cómo podrem & 154 lef501083.txt 7 \\
\hline 19 I pobre ciudadano que tiene todo el sueldo consumido por los impuestos, muchos de e & 342 lef501123.txt \\
\hline 20 ersonalidad, es algo que debe ser muy bien pensado. El egoísmo no está en la "tranqui & 176 ee500204.txt $\varepsilon$ \\
\hline 21 ermelada que, de modo sorprendente, vino acompañado de una mosca en su contenid & 29 ee500671.txt \\
\hline 22 tal medida. Quizás, tal crimen pueda ser reparadocon una prisión perpetua, onde & 199 ee500703.txt 4 \\
\hline 23 blación. Quiero resaltar que el bote estaba cerrado y el sello de segurança estaba inta & 178 ee500911.txt 5 \\
\hline 24 olencia? Por supuesto que Carlos debe ser punido por su crimen. Sólo no debe morir p & 182 lef501083.txt $\varepsilon$ \\
\hline 25 sino de los niños también, ya que, un chico criado con pocos recursos, principalmente & 81 ee500674.txt 5 \\
\hline 26 te por infanticídio. Tratase de un caso muy comentado, en todos los periódicos del mu & 33 ee500703.txt \\
\hline 27 de hijos también es un punto que debe ser llevadoen cuenta, de acuerdo con las dispo & 42 lef500874.txt \\
\hline 28 iligencias y investigaciónes el crimen fueraesclarecido y el vigilantese ha declarado & 85 ee500703.txt \\
\hline 29 uscó por toda la ciudad y mi marido no fue encuentradoen ninguna parte. Hizo anunc & 207 ee500701.txt 5 \\
\hline
\end{tabular}

Fig. 1: Extrato das concordâncias para os particípios em -DO (Avançado 1 - C2)

Essas lematizações também permitiriam incluir no levantamento as formas agramaticais que porventura incidissem no corpus, tais como *dizido, "volvido, ${ }^{*}$ feito, ${ }^{*}$ fecho, *escrivido, ${ }^{*}$ ponido, *dito, etc.

O uso dos lemas referidos anteriormente resultou numa primeira filtragem de $\mathrm{C} 2$, produzindo as linhas de concordância que continham as estruturas de interesse para esta pesquisa. Uma segunda filtragem permitiu eliminar as concordâncias desnecessárias para o estudo em questão; por exemplo, foram apagadas as linhas cujos nódulos constavam de formas como mucho/a/os/as, ancho/a/os/as, abogado, plato/a, ocho, derecho, etc. O quadro da tabela 9 ilustra o processo para o subcorpus B2. 


\begin{tabular}{|l|c|c|}
\hline \multirow{2}{*}{ LEMAS } & \multicolumn{2}{|c|}{$\mathbf{N}^{\circ}$ DE CONCORDÂNCIAS } \\
\cline { 2 - 3 } & INICIAL & $\begin{array}{c}\text { APÓS } \\
\text { FILTRAGEM }\end{array}$ \\
\hline${ }^{*}$ DO & 1828 & 22 \\
\hline${ }^{*}$ DA & 518 & 34 \\
\hline${ }^{*}$ DOS & 386 & 14 \\
\hline${ }^{*}$ DAS & 129 & 6 \\
\hline${ }^{*}$ TO & 526 & 6 \\
\hline${ }^{*}$ TA & 583 & 4 \\
\hline${ }^{*}$ TOS & 195 & 1 \\
\hline${ }^{*}$ TAS & 140 & 2 \\
\hline${ }^{*}$ CHO & 292 & 1 \\
\hline${ }^{*}$ CHA & 49 & 2 \\
\hline${ }^{*}$ CHOS & 81 & 2 \\
\hline${ }^{*}$ CHAS & 101 & 2 \\
\hline
\end{tabular}

Tab. 9: Concordâncias para o subcorpus B2 (C2)

O inventário das construções com se também foi feito com o auxílio da ferramenta Concord, usando-se o lema *SE para gerar as concordâncias. Eliminando-se as linhas não relevantes para a pesquisa, restaram 81 concordâncias com se (ver tabela 10).

\begin{tabular}{|c|c|c|}
\hline \multirow{2}{*}{ SUBCORPORA } & \multicolumn{2}{|c|}{$\mathbf{N}^{\circ}$ DE CONCORDÂNCIAS COM SE } \\
\cline { 2 - 3 } & INICIAL & $\begin{array}{c}\text { APÓS } \\
\text { FILTRAGEM }\end{array}$ \\
\hline B1 & 749 & 3 \\
\hline B2 & 493 & 14 \\
\hline I1 & 238 & 10 \\
\hline I2 & 210 & 19 \\
\hline A1 & 141 & 17 \\
\hline A2 & 120 & 17 \\
\hline TOTAL & - & 80 \\
\hline
\end{tabular}

Tab. 10: Concordâncias para as construções com se (C2)

Em síntese, para o corpus C2, o levantamento das FVP foi feito conforme a seqüência: 
1) subdivisão de $C 2$ em 6 subcorpora (B1, B2, I1, I2, A1 e A2);

2) processamento do primeiro subcorpus no programa WordSmith Tools, obtendo-se índices estatísticos (ferramenta WordList) e concordâncias (ferramenta Concord);

3) leitura das concordâncias, eliminando aquelas sem interesse para a pesquisa;

4) identificação das estruturas desejadas;

5) classificação dessas estruturas;

6) repetição dos passos anteriores para os demais subcorpora;

7) tabulação dos padrões observados e suas freqüências.

Para todo o corpus, o resultado do levantamento pode ser melhor visualizado na tabela 11 (ver produções em CORPORA, Corpus C2, p. 157).

\begin{tabular}{|c|c|c|c|c|c|c|c|}
\hline \multirow{2}{*}{ LEMAS } & \multicolumn{6}{|c|}{$\mathrm{N}^{\circ}$ DE CONCORDÂNCIAS APÓS FILTRAGEM } & \multirow{2}{*}{ TOTAL } \\
\hline & B1 & B2 & 11 & 12 & A1 & A2 & \\
\hline${ }^{\circ} \mathrm{DO}$ & 35 & 22 & 22 & 18 & 29 & 10 & 136 \\
\hline${ }^{\circ} \mathrm{DA}$ & 23 & 34 & 21 & 19 & 17 & 13 & 127 \\
\hline "DOS & 3 & 14 & 11 & 17 & 9 & 4 & 58 \\
\hline "DAS & 3 & 6 & 8 & 11 & 4 & 14 & 46 \\
\hline *TO & - & 6 & - & 5 & - & - & 11 \\
\hline${ }^{*} \mathrm{TA}$ & - & 4 & 2 & 1 & 2 & - & 9 \\
\hline *TOS & - & 1 & 1 & - & - & - & 2 \\
\hline${ }^{*}$ TAS & - & 1 & - & - & 1 & - & 2 \\
\hline${ }^{*} \mathrm{CHO}$ & - & 2 & 1 & 1 & 1 & - & 5 \\
\hline${ }^{*} \mathrm{CHA}$ & - & 1 & - & 2 & 1 & 1 & 5 \\
\hline${ }^{*} \mathrm{CHOS}$ & 2 & 2 & 1 & - & 1 & - & 6 \\
\hline${ }^{*} \mathrm{CHAS}$ & - & 2 & 3 & - & - & 1 & 6 \\
\hline${ }^{*} \mathrm{SE}$ & 4 & 14 & 10 & 19 & 17 & 17 & 80 \\
\hline TOTAL & 70 & 109 & 80 & 93 & 82 & 60 & 493 \\
\hline
\end{tabular}

Tab. 11: Concordâncias levantadas para C2 


\section{II.4. Os padrões esperados nos corpora}

Baseado na análise feita para o verbo pensar ${ }^{74}$, considerei a possibilidade de incidência das FVP, em C1 e C2, segundo os padrões a seguir ${ }^{75}$ :

(1) [ser + participio], incluindo a conjugação de ser com tempos simples (Un hombre fue detenido hoy en aplicación de la Ley de Terrorismo del Reino Unido (...) - LV, 10/10/06), com tempos compostos (El primer ministro turco, Recep Tayyip Erdogan, que había sido hospitalizado en la mañana de hoy en Ankara, salió del centro médico y se dirigirá a su domicilio para reposar, informaron los medios locales. - $L V, 18 / 10 / 06)$ e a construção com infinitivo (Dos de ellos, el sargento Paul E. Cortez y el soldado de primera Jesse V. Spielman, se enfrentan a la posibilidad de ser condenados a muerte (...) LV, 19/10/06);

(2) [verbo + infinitivo de ser + particípio] ( (...) Manakli pudo ser sometido a torturas antes del juicio, en el que admitió los cargos. - LV, 10/10/06);

(3) [estar + participio], incluindo a conjugação de estar com tempos simples (Fuentes de Los Verdes dijeron que de cara al acuerdo para el Parlamento europeo aún no están pensados ni cerrados los nombres (...) - LV, 22/01/04), com tempos compostos (Los casi 10 kilómetros que ha recorrido el robot en su misión han estado plagados de contratiempos (...) - LV, 06/10/06) e a construção com infinitivo (Tras el visionado en repetidas ocasiones del anuncio, el juez estima que "concurren razones de urgencia que aconsejan en este momento la suspensión de la emisión" del anuncio, principalmente por estar protagonizado por niños (...) - LV, 05/10/06);

(4) [verbo + infinitivo de estar + participio] ( (...) el vehículo en el que se produjo la explosión podía estar alimentado por gas (...) - LV, 25/03/05);

\footnotetext{
${ }^{74}$ Ver item I.2., p. 28 e seguintes.

${ }^{75}$ Os exemplos que acompanham cada padrão foram selecionados do jornal espanhol La Vanguardia, que abreviarei como $L V$.
} 
(5) [verbo (diferente de ser e estar) + participio] (Pujol ha advertido de que el "boom" económico español viene acompañado de factores preocupantes, como una "gran pérdida de competitividad y de productividad" y un "creciente déficit comercial". - LV, 30/06/06);

(6) particípio com sentido pasivo (La presidenta explicó que el funcionamiento interno de la entidad es igual que el de otras asociaciones, con junta directiva, elecciones democráticas y miembros que pagan sus cuotas, definidas como "voluntarias". - LV, 14/09/06);

(7) [se + verbo na $3^{\mathrm{a}}$ Pessoa], em tempos simples (El 11 de marzo de 2004 se perpetró el mayor atentado sufrido en territorio español. $-L V, 11 / 07 / 06)$ ou compostos (En él se refleja que, "hasta el momento, no se han encontrado indicios de deficiencias técnicas ni en la infraestructura ni en el material rodante". - LV, 24/08/06);

(8) [se + locução verbal] (El Reglamento General de Circulación especifica que siempre que la señalización indique "anuncio de precaución" se debe reducir la velocidad a 30 kilómetros por hora. $-L V, 24 / 08 / 06)$.

A quantificação dos padrões efetivamente observados nos corpora C1 e C2 é o tema do capítulo subseqüente. Nesse capítulo, os exemplos extraídos dos corpora serão representados da seguinte forma:

a) Para o corpus $\mathrm{C} 1$ :

El juego humano es un fenómeno de la cultura transmitido por la educación y el juego del animal es puramente instintivo, relativo a su supervivencia dentro de un grupo (C1: I2.C.2)

A notação entre parênteses significa que o exemplo citado é do corpus C1 e está no subcorpus Intermediário II - C (I2.C), sendo o segundo (2) na ordem de descrição desse subcorpus (I2.C.2 é o número 2 numa seqüência de 6 exemplos). 
b) Para o corpus C2:

Sin embargo, no es justo con el pobre ciudadano que tiene todo el sueldo consumido por los impuestos, muchos de estos usados para mantener criminosos en la cárcel sin que trabajen, con comida y salud garantizados por un gobierno que no proporciona eso a su pueblo. (C2: EF501123)

A notação entre parênteses significa que o exemplo citado é do corpus C2 e foi extraído de EF501123, ou seja, da terceira produção (3) do informante 112 do EEC (E), que cursava o nível Avançado 2 (5) no primeiro semestre de 2006 $(\mathrm{F})^{76}$.

${ }^{76} \mathrm{O}$ sistema de codificação das produções de C2 pode ser mais bem visualizado nas tabelas 5, 6 e 7 do item II.2.2. 
CAPÍTULO III

Os resultados

\section{III.1. Os resultados obtidos e seus padrões de incidência}

No final do capítulo anterior, citei os padrões esperados para as FVP nos corpora $\mathrm{C} 1$ e C2. A seguir, apresento os resultados obtidos por meio da análise das concordâncias e para cada um desses padrões.

(1) [ser + particípio], incluindo a conjugação de ser com tempos simples, com tempos compostos e a construção com infinitivo

Ocorreu nos dois corpora, conforme os exemplos ${ }^{77}$ a seguir:

(a) Como Francisco no percibió que el tiburón estaba tras del bote, fue atacado por él. El bote, el pájaro y Francisco fueron lanzados al aire. (C1: I2.B.3)

(b) Volvendo al mismo sitio luego por la mañana, nos hemos sido recibidos con los brazos abiertos, por un batallon de seres semejantes los hombres terrícolas (...) (C2: EB200602)

(c) Después del cárcel, procura llevar una vida normal hasta ser acusado de un crimen que no practicó. (C2: EA100712)

(2) [verbo + infinitivo de ser + particípio]

Ocorreu nos dois corpora, conforme os exemplos a seguir:

(a) La razón para ese odio, que se convierte en asaltos, palizas y asesinatos a sangre fría, puede ser explicada por el miedo que emerge cada vez mais en grande parte de la Europa de hoy (...) (C1: A2.C.2)

(b) Sus iglesias también deben ser visitadas poes son todas de lo siglo pasado y nos llevan a un contacto próximo con Dios. (C2: EC300402)

(3) [estar + particípio], incluindo a conjugação de estar com tempos simples, com tempos compostos e a construção com infinitivo

Ocorreu nos dois corpora, conforme os exemplos a seguir:

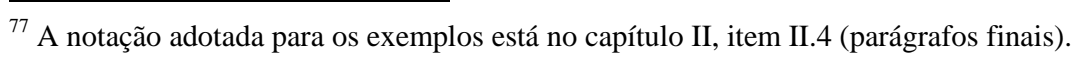


(a) A causa de eso [un accidente], por lo que sé, todas las funerarias están siendo solicitadas hoy. (C1: I2.C.5)

(b) El bote estaba cerrado, con el lacre de la empresa, donde se puede leer la información de seguridad "no la compre si ya se rompió el lacre". (C2: EE500021)

(4) [verbo + infinitivo de estar + particípio]

Ocorreu uma vez, e apenas em C2:

Hemos encontrado algunos objetos que parecen indícios de que alguno tipo de vida inteligente vivió allí. Puede já estar extinta porque el sitio parece abandonado. (C2: EB200492)

(5) [verbo (diferente de ser e estar) + particípio]

Ocorreu apenas em C2:

Como compré un tarro de mermelada que, de modo sorprendente, vino acompañado de una mosca en su contenido, me tomo la libertad de enviarles esta carta con el fin de que ustedes tomen una providencia con relación al establecimiento comercial responsable por esa venta que considero, al mínimo, equivocada. (C2: EE500671)

(6) particípio com sentido pasivo

Ocorreu nos dois corpora, conforme os exemplos a seguir:

(a) El juego humano es un fenómeno de la cultura transmitido por la educación y el juego del animal es puramente instintivo, relativo a su supervivencia dentro de un grupo (C1: I2.C.2)

(b) Sin embargo, no es justo con el pobre ciudadano que tiene todo el sueldo consumido por los impuestos, muchos de estos usados para mantener criminosos en la cárcel sin que trabajen, con comida y salud garantizados por un gobierno que no proporciona eso a su pueblo. (C2: EF501123)

(7) [se + verbo na $3^{\text {a }}$ pessoa], em tempos simples ou compostos e em construções com infinitivo

Ocorreu nos dois corpora, conforme os exemplos a seguir:

(a) Paz y Dani, por ejemplo, se presentan como jóvenes que tienen dudas, hacen descubiertas, quieren se enamorar como cualquiera, pero son obligados a enfrentar situaciones que los madurese. (C1: A2.C.12) 
(b) No hay cenas mucho calientes, no se muestran cenas de sexo, la atención del público es llamada pelos diálogos intrigantes y irónicos de los personajes. (C2: ED400273)

(c) Pero luego vi que mis maletas se habían descaminado, por lo tanto fue asta la intendencia para tener ayuda. (C2: EF600121)

(d) ¿Por qué tener hijos? Ésta es una pregunta dificil de se contestar. (C2: EF501114)

(8) [se + locução verbal]

Ocorreu nos dois corpora, conforme os exemplos a seguir:

(a) Sin duda, se puede decir que la película tiene como eje fundamental una historia de amor que es afectada por el mundo del prejuicio y del racismo. (C1: A2.C.4)

(b) ¿En Brasil se deve adoptar la pena de muerte? (C2: EE500403)

A tabela 12 contém as quantificações das incidências por padrão.

\begin{tabular}{|c|c|c|c|c|}
\hline \multirow{2}{*}{ PADRÃO } & \multicolumn{2}{|c|}{ C1 } & \multicolumn{2}{c|}{ C2 } \\
\cline { 2 - 5 } & INCIDÊNCIAS & $\%$ & INCIDÊNCIAS & $\%$ \\
\hline$(1)$ & 36 & 50 & 180 & 36,51 \\
\hline$(2)$ & 5 & 6,94 & 41 & 8,32 \\
\hline$(3)$ & 1 & 1,4 & 26 & 5,27 \\
\hline$(4)$ & - & - & 1 & 0,2 \\
\hline$(5)$ & - & - & 6 & 1,22 \\
\hline$(6)$ & 16 & 22,22 & 159 & 32,25 \\
\hline$(7)$ & 5 & 6,94 & 61 & 12,37 \\
\hline$(8)$ & 9 & 12,5 & 19 & 3,86 \\
\hline TOTAL & 72 & 100 & 493 & 100 \\
\hline
\end{tabular}

Tab. 12: Incidências dos padrões nos corpora

\section{III.2. Classificação e inventário das FVP nos corpora}

Os padrões (1), (2), (3), (4) e (5) têm em comum a presença de um verbo (ser, estar, poder, deber, etc., no infinitivo, em tempos simples ou compostos) seguido de um particípio (ou perífrase de particípio). Portanto, reuni-os em uma mesma categoria e, seguindo a nomenclatura de Moino (ver I.3., p.40), classifiquei suas ocorrências como FVP sintáticas. Em C1, as FVP sintáticas ocorreram 41 vezes $(60,3 \%)$; em C2, esse número atingiu 254 incidências (51,5\%). 
Ainda segundo a nomenclatura de Moino (ibid.), classifiquei as ocorrências do padrão (6) como FVP lexicais, cujos totais e percentuais nos corpora $\mathrm{C} 1$ e $\mathrm{C} 2$ podem ser vistos na tabela 12. Para melhor entendimento dos critérios de classificação, tomemos um dos exemplos citados em III.1.(6):

(6b) Sin embargo, no es justo con el pobre ciudadano que tiene todo el sueldo consumido por los impuestos, muchos de estos usados para mantener criminosos en la cárcel sin que trabajen, con comida y salud garantizados por un gobierno que no proporciona eso a su pueblo. (C2: EF501123)

No referido exemplo há três FVP lexicais, que aparecem na seguinte ordem:

(1) (...) que tiene el sueldo consumido por los impuestos

(2) (...) muchos de estos usados para mantener criminosos (...)

(3) (...) con comida y salud garantizados por un gobierno (...)

Em (1) e (3) pode-se verificar a presença do agente (impuestos e gobierno, respectivamente); já em (2) o agente encontra-se ausente, embora recuperável por meio de uma referência catafórica ${ }^{78}$, em (3). Ou seja, considero que as construções (2) e (3) têm o mesmo agente: conforme se pode concluir de (6b), o responsável pela destinação dos impostos e pela garantia de alimentação e tratamento médico aos presidiários é um só - o gobierno. No caso de (6b), agentes explícitos ou recuperáveis não deixam dúvida acerca do caráter passivo da construção. Entretanto, alguns casos em que o agente não aparece e não é recuperável podem resultar ambíguos e por isso têm de ser analisados com atenção. É o caso do fragmento a seguir:

Él es bombero, gusta caminar, nadar, leer, ver una partida de fútbol. Elle es un hombre fascinante, es muy alto, delgado, pelo curto alisado, ojos verdes, boca carnosa. (C2: EC101542)

\footnotetext{
${ }^{78}$ Segundo a lingüística textual, um elemento de referência é catafórico quando a sua interpretação depende de algo que se segue no texto (Fávero \& Koch, 2000:40). Por exemplo: Esta foi a resolução da diretoria: que os alunos inadimplentes sejam impedidos de freqüentar as aulas. Na sentença, o termo em negrito só pode ser interpretado a partir do fragmento sublinhado. Adaptando a definição de catáfora ao exemplo (6b), poderíamos afirmar que o leitor recupera o agente ausente em (2), graças à presença posterior dessa entidade, em (3).
} 
Considero que o particípio alisado, junto ao SN pelo curto, tem comportamento mais adjetival que verbal, reforçado pelo fato de a construção estar inserida numa seqüência descritiva, junto a outras estruturas semelhantes (hombre fascinante, ojos verdes, boca carnosa). Portanto, não a classifiquei como uma FVP lexical. Pela mesma razão, ocorrências nos corpora tais como pelo teñido, agua contaminada, deber cumplido, distribuidora autorizada, piso alquilado, etc. tampouco foram consideradas FVP lexicais.

Os padrões (7) e (8) correspondem às construções com se observadas nos corpora. Classifiquei como FVP pronominais aquelas cujo comportamento passivo é inequívoco. Em C1, computei 4 incidências de FVP pronominais $(5,9 \%)$, das quais cito o exemplo a seguir:

(1) (...) El restaurante de primera categoría no era más que un balcón donde se podían comer bocadillos y beber tequilla. (C1: A1.3)

Em C2, contabilizei 8 casos de FVP pronominais $(1,6 \%)$, dentre as quais o seguinte exemplo:

(2) Visitamos a la iglesia del centro, fuimos a las ferias donde se venden muchas bizuterías y enfeites en general, pero nada importante. (C2: ED201394)

Considerei (1) e (2) como FVP pronominais com base na concordância entre os $\mathrm{SN} /$ pacientes (bocadillos e muchas bizuterías y enfeites, respectivamente) e as formas verbais ativas das sentenças (podían e venden), ambos no plural. Entretanto, sabe-se que esse critério não é de todo confiável, dada a freqüência de construções com se nas quais a concordância é suprimida: tal fato ocorre no PB, em todos os registros (Aluga-se casas é um clássico exemplo), assim como no Espanhol, conforme apontam diversos estudos gramaticais (embora mais associado às formas coloquiais da língua, sobretudo na modalidade oral ${ }^{79}$ ).

\footnotetext{
${ }^{79}$ Cf. González (1994:393). Sobre a questão, Rodolfo Lenz (apud Fernández Ramírez, 1986:416) propôs eliminar da gramática escolar o capítulo da voz passiva em castelhano. Afirma Fernández Ramírez: "al examinar las concordancias del tipo: se vende frutos del país [Rodolfo Lenz] piensa que la preferencia por la anteposición del pronombre se en las construcciones pasivo-reflejas se debe a que la conciencia lingüística más ingenua interpreta el sujeto originario (frutos en el ejemplo de Lenz) como complemento directo del verbo. El hecho es evidente y esa interpretación favorece el fenómeno moderno de la pérdida de la concordancia.”
} 
As demais ocorrências foram classificadas como indefinidas ${ }^{80}$, já que seria possível considerá-las como FVP pronominais ou como impessoais. Em C1, o número de ocorrências das construções indefinidas foi de 10 (14,7\%):

(3) Algunas horas después nada más se podía mirar, solamente el agua por todo lado. (C1: I2.B.4)

Em C2, contabilizei 72 construções indefinidas (14,6\%):

(4) Los turistas brasileños son muy alegres y festivos, así es que para agradarlos hay que ser informal y cariñoso. A ellos les gusta que se use expressiones como: "(mi) cariño", "(mi) precioso", etc. (C2: ED400214)

Em (3), o SN/paciente (nada más) e o verbo estão no singular, o que torna a sentença ambígua do ponto de vista sintático: pode ser tanto passiva quanto impessoal. Em (4), o SN/paciente (expresiones) está no plural e o verbo está no singular, o que nos permitiria considerá-la como impessoal, segundo a classificação tradicional. Entretanto, considerando-se a supressão da concordância nas estruturas com se como um dado emergente no PB e no Espanhol, (4) seria tão ambígua quanto (3). Resolver o impasse demandaria uma abordagem das estruturas impessoais no PB e no Espanhol, o que está fora do escopo deste trabalho. Apenas ressalto a baixa ocorrência de estruturas com o clítico se (sejam FVP pronominais ou construções impessoais) na produção dos aprendizes - tanto em $\mathrm{C} 1$ como em $\mathrm{C} 2-$, o que a distanciaria do Espanhol.

Uma melhor visualização das ocorrências de FVP nos corpora C1 e C2 pode ser vista nas figuras 2 e 3 . Segundo esses gráficos, as incidências de cada uma das construções é proporcionalmente a mesma nos dois corpora. Também é notória em ambos a preferência dos aprendizes pelas construções passivas de particípio: as FVP sintáticas e lexicais totalizam $79,4 \%$ de $\mathrm{C} 1 \mathrm{e}$ $83,8 \%$ de C2. Por serem essas construções as mais relevantes para esta pesquisa, passo a analisá-las nos itens subseqüentes.

\footnotetext{
${ }^{80} \mathrm{O}$ termo INDEFINIDAS é controverso, porém utilizo-o aqui por não dispor de outro que defina com mais precisão essa ambigüidade entre passivais e impessoais, que se dá em parte pela supressão da concordância.
} 


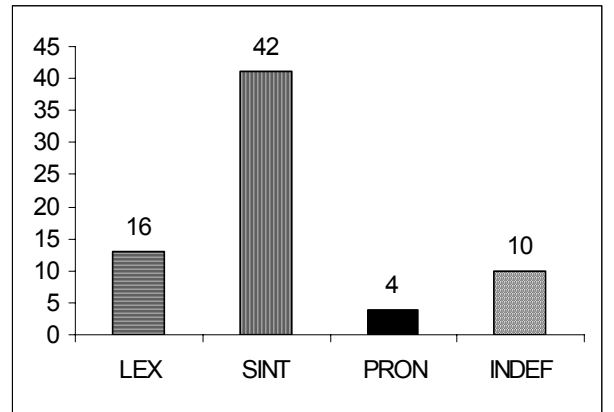

Fig. 2: Ocorrências por construção (C1)

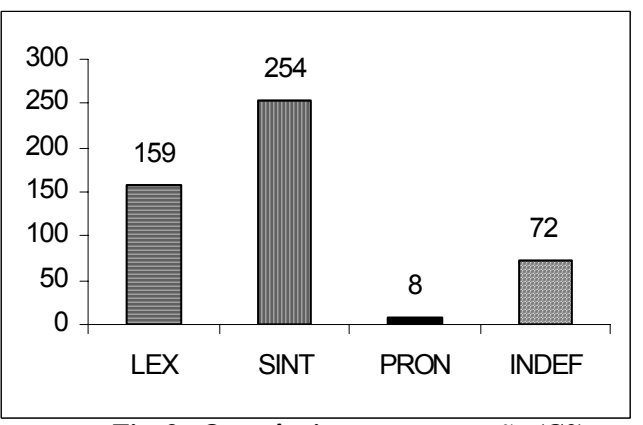

Fig. 3: Ocorrências por construção (C2)

\section{III.3. Análise das FVP de particípio}

\section{III.3.1. O agente}

\section{III.3.1.1. PRESENÇA vs. AUSÊNCIA}

Em C1, para as FVP de particípio, os dados referentes à presença ou ausência do agente estão dispostos na figura 4.

Nas FVP lexicais, as construções [+agente] (5) totalizam 43,7\% , enquanto as [-agente] (6) chegam a $56,3 \%$ :

(5) A pesar de toda la violencia presente en la película, el guión, escrito por Santiago Tabernero, se estructura alrededor de una historia de amor entre dos jóvenes, hijos de dos de los taxistas referidos arriba. (C1: A2.C.5)

(6) Las profesiones presentadas son muy distintas, pero de extremo valor para la humanidad. (C1: A2.B.3)

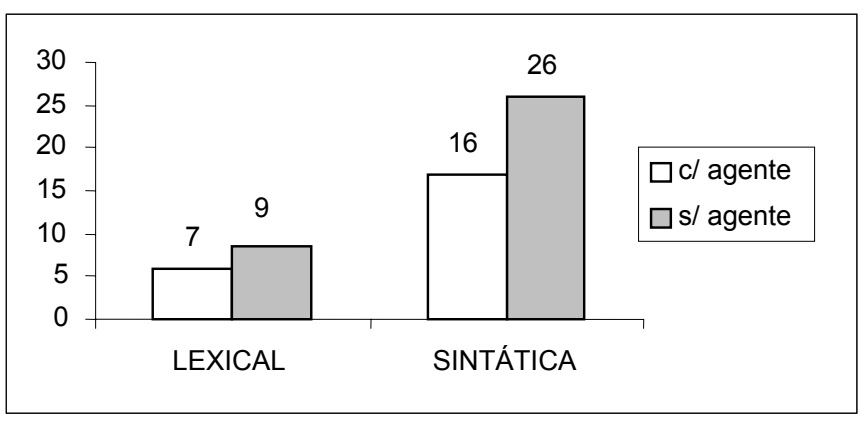

Fig. 4: Presença/ausência do agente nas FVP de particípio (C1) 
Nas FVP sintáticas, as estruturas [-agente] (7) ocorrem em $62 \%$ dos casos, superando as [+agente] (8), com 38\%:

(7) El aparcamiento era tan bien "vigilado" que nos chocaron el coche, rompiéndole todos los vidrios. (C1: A1.6)

(8) (...) Les escribimos después de habermos sido robados por su agencia. (C1: A1.5)

Considerando as duas variedades em conjunto, as passivas [-agente] incidem em $60 \%$ dos casos, contra $40 \%$ de passivas [+agente]. Há, portanto, em $\mathrm{C} 1$, uma tendência à aparição de passivas [-agente].

Para o corpus $\mathrm{C} 2$, temos os seguintes dados (figura 5):

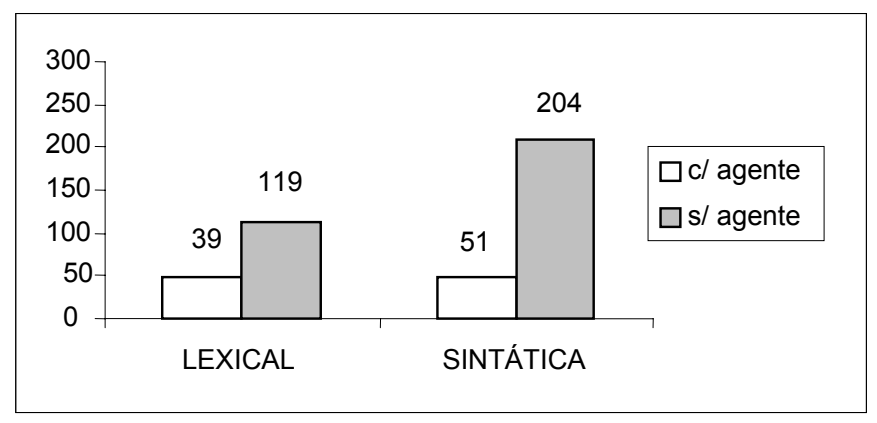

Fig. 5: Presença/ausência do agente nas FVP com particípio (C2)

Nas FVP lexicais, as construções [+agente] (9) totalizam 25\%, enquanto as [-agente] (10) incidem 3 vezes mais (75\%):

(9) Sin apoyo y buscado pela policía, el teniente tem que probar su inocencia y salvar todas las personas y acaba con la organización criminosa. (C2: EA100752)

(10) El museo,con grandiosas proporciones posee objetos indigenas, mobiliario, armas, pinturas, ferramientas, coches, vestimentas y muchos otros objetos. Ya el parque, recientemente reformado, posee bellos jardines. (C2: EC300882)

Nas FVP sintáticas, as FVP [-agente] (11) ocorrem em $80 \%$ dos casos, superando em quatro vezes as [+agente] (12), com $20 \%$ :

(11) Como todos los saben en el Brasil las personas son muy simpaticas y amaveis, tiene que tratarlos muy bien, porque pueden ser un povo muy bueno, pero todos adoran ser bien tratados. (C2: ED400744)

(12) Creo que tener hijos actualmente es una tarea compleja porque es muy caro. Además, los padres tienen que trabajar y no pueden criarlos, sino que los niños son criados por canguros! (C2: EF501134) 
Considerando as duas variedades em conjunto, as FVP [-agente] incidem em $78 \%$ dos casos, contra $22 \%$ de FVP [+agente]. Em C2, portanto, confirmase categoricamente a tendência à aparição das FVP [-agente]. Para os dois corpora de aprendizes, esses resultados estão em conformidade com os observados no PB e no Espanhol.

Em C1, dos 35 casos de ausência de agente computados, 14 (40\%) se devem a uma menção prévia dessa entidade no discurso, o que tornaria desnecessária a sua repetição. Ainda em C1, em 4 ocorrências $(11,4 \%)$ os agentes podem ser inferidos pelo leitor, o que também dispensaria explicitá-los no discurso. Em C2, o número de incidências de FVP [-agente] foi de 323, dos quais $55(17 \%)$ têm menções prévias ${ }^{81}$ e $86(26,6 \%)$ podem ser determinados por inferência. Como exemplos do agente não explícito, porém recuperável por menção prévia, cito:

(13) Como Francisco no percibió que el tiburón estaba tras del bote, fue atacado por él. El bote, el pájaro y Francisco fueron lanzados al aire. (C1:I2.B.3)

(14) He intentado hacer comunicación con uno de ellos, que se ha parecido su líder y, para mi admiración, he sido comprendido, pues he visto que tenían algo como un radio traductor de lenguajes universal. (C2: ED201392)

Em (13) e (14), as expressões sublinhadas são os agentes das FVP em negrito. Como exemplos de agentes que podem ser inferidos, tem-se:

(15) Saura muestra en su obra su rechazo por todas las formas de prejuicio existente en su país hoy día, debiendo ser vista no solamente como una forma de denuncia de una dura realidad, pero también como una arma de transformación de la sociedad. (C1: A2.C.6)

(16) ¿Cómo punir la violencia con violencia? Por supuesto que Carlos debe ser punido por su crimen. Sólo no debe morir por eso. (C2: EF501083)

Em (15) e (16), respectivamente, poderíamos pensar em "público" e "justiça" como agentes das construções passivas em negrito.

\footnotetext{
${ }^{81}$ Houve pouquíssimos casos em que a referência ao agente não é prévia, e sim posterior à construção passiva, como em: Nuestro coche fue estropeado en el aparcamiento. No había vigia, pero habia ladrones. (C1: A1.8) Para melhor compreensão, contextualizo o leitor: a produção da qual se extraiu o exemplo era uma carta formal, em que um cliente lesado queixava-se dos péssimos serviços oferecidos pelo hotel onde se hospedou. O pacote oferecia estacionamento vigiado, porém o hóspede teve seu carro danificado e seus pertences roubados.
} 


\section{III.3.1.2. AGENTE [+humano] vs. [-humano]}

Para melhor fundamentar a minha opção por opor os traços [+humano] e [-humano] para o agente, exponho a seguir algumas definições desse papel temático encontradas na literatura:

1) O agente é o indivíduo que tem a iniciativa da ação, que tem controle sobre a realização da ação (llari, 2001:131);

2) O agente é a função desempenhada por um ente animado que é responsável, voluntária ou involuntariamente, pela ação ou pelo desencadeamento dos processos (Fillmore, 1968, apud Cançado, 2003:97);

3) O agente é o elemento controlador da ação (Hallyday, 1967, apud Cançado, 2003:97);

4) O agente é algo que realiza a ação; incluindo aí animados, forças naturais e inanimados (Chafe, 1970, apud Cançado, 2003:97).

As entidades [+humano], por reunir a maioria das características presentes nessas definições (poder, força, iniciativa da ação, vontade, controle), assumem mais freqüentemente o papel de agente. Poder-se-ia também opor [+animado]/ [-animado]; porém, de acordo com os trabalhos de autores aqui citados (Miñones \& Sánchez, por exemplo) e com os dados dos meus corpora, no grupo [+animado] a maioria das entidades também é [+humano]. Portanto, no que concerne ao agente, priorizo a oposição [+humano]/ [-humano].

Em C1, para as FVP de particípio, as incidências relativas aos agentes [+humano] e [-humano] estão esquematizadas na figura 6.

Nas FVP lexicais, as construções com agente [+humano] (17) totalizam $71 \%$ e as com agente [-humano] (18) chegam a $29 \%$ :

(17) Paz, interpretada de forma magnífica por Ingrid Rubio, es el personaje más fuerte de la trama. (C1: A2.C.15)

(18) (...) Se entregó por un momento a aquella tranquilidad vigilada por una gaviota. (C1: I2.A.1) 


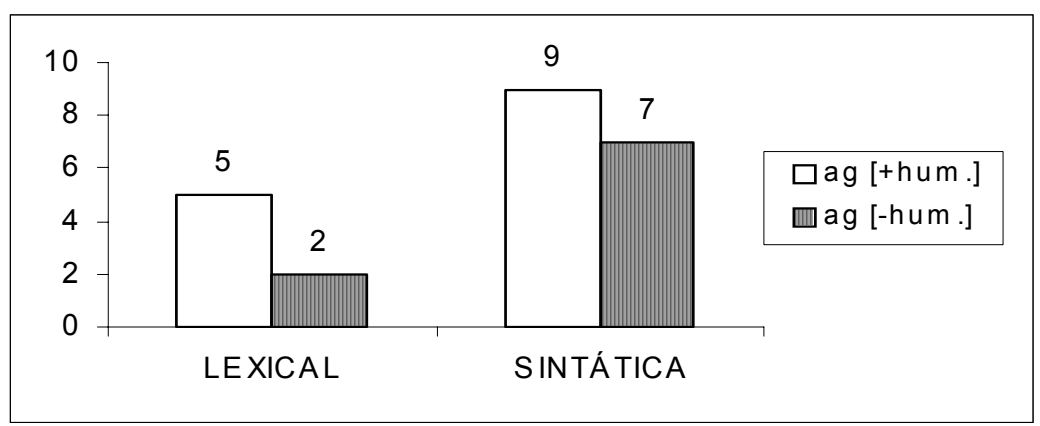

Fig. 6: Ocorrência de agente [+/-humano] nas FVP de particípio (C1)

Nas FVP sintáticas, as construções com agente [+humano] (19) ocorrem em $56 \%$ dos casos, superando as com agente [-humano] (20), cuja incidência foi de 44\%:

(19) El film es ambientado en Madrid, y empieza cuando Paz, tras haber suspendido en los exámenes, es obligada por su padre taxista a trabajar en su profesión. (C1: I2.A.1)

(20) Dani, aunque compartiese la misma opinión de los fachas, es bastante influenciado por las ideas de Paz, de quien se enamora. (C1: A2.C.20)

Considerando as duas variedades em conjunto, as FVP com agentes [+humano] incidem em $61 \%$ dos casos, contra $39 \%$ de agentes [-humano] portanto, uma vantagem razoável das primeiras sobre as segundas.

Para o corpus C2, temos os seguintes dados (figura 7):

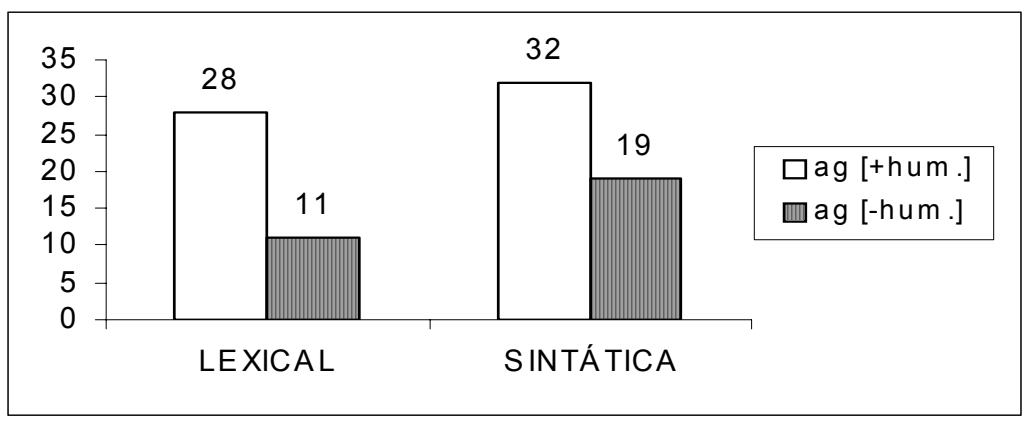

Fig. 7: Ocorrência de agente [+/-humano] nas FVP com particípio (C2)

Nas FVP lexicais, as construções com agente [+humano] (21) totalizam $72 \%$ e as com agente [-humano] (22) chegam a $28 \%$ : 
(21) Ante todo quiero registrar mi inmensa admiración y respecto por todas las actividades desarrolladas por el sector de producciones culturales del "Hotel 35", gracias a mi propia experiencia como usuaria de sus servicios. (C2: EF600023)

(22) Sensible y profundo, una pelicula realmente maravillosa. Dos vidas marcadas por una historia de pasión que jamás podría ser contada. (C2: ED400403)

Nas FVP sintáticas, as construções com agente [+humano] (23) ocorrem em $63 \%$ dos casos, superando as com agente [-humano] (24), cuja incidência foi de $37 \%$ :

(23) (...) Cada uno entiende como le conviene. En ese caso, la situación fue mal interpretada por Mário.(C2: EF600495)

(24) Salto está cortado por el río Tiete, que lamentablemente hoy, se encuentra contaminado, pero antiguamente era navegable y muchas personas nadaban en él. (C2: EC300282)

Considerando as duas variedades em conjunto, as FVP com agentes [+humano] incidem em $67 \%$ dos casos: o dobro das ocorrências das FVP com agentes [-humano] (33\%). Portanto, verifica-se nos dois corpora de aprendizes a tendência observada no PB e no Espanhol: o maior número de agentes [+humano].

\section{III.3.2. O paciente}

\section{III.3.2.1. PACIENTE [+humano] vs. [-humano]}

Para as FVP de particípio, no corpus $\mathrm{C} 1$, os dados referentes ao traço [+humano] e [-humano] no paciente estão esquematizados na figura 8.

De acordo com os dados, o paciente [-humano] foi majoritário nas duas variedades, figurando em $87,5 \%$ das FVP lexicais (25) e $55 \%$ das FVP sintáticas (26):

(25) Al visitar el museo nuestra orientación fue solamente el libreto recibido en su portaria, pues no habia guias para nos ayudar. (C1: A1.9)

(26) ¡Yo ahora sé que el aparcamiento es vigilado por ladrones, que nos roban las partes del coche! (C1: A1.11) 


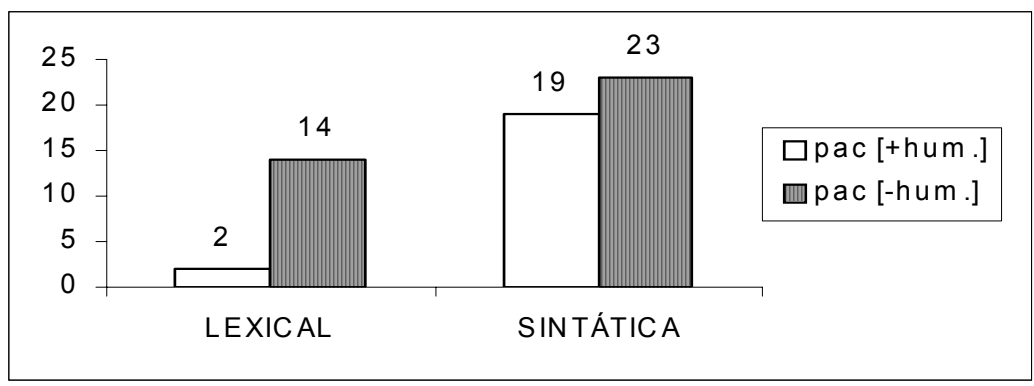

Fig. 8: Ocorrência de paciente [+/-humano] nas FVP de particípio (C1)

Considerando as variedades em conjunto, temos pacientes [-humano] em $64 \%$ das incidências, o que está de acordo com a tendência observada no PB e no Espanhol.

Em C2, a incidência de pacientes [-humano] também foi predominante nas duas variedades (ver figura 9). Aparece em 76\% das FVP lexicais (27) e $57 \%$ das FVP sintáticas (28):

(27) Camila sueña ser protagonista de una película guiada por el guionista David Lynch. (C2: EA100872)

(28) En 1799, las tierras de esa región fueron arrendadas y transformadas en una hacienda llamada Hacienda Butantã. (C2: EC300892)

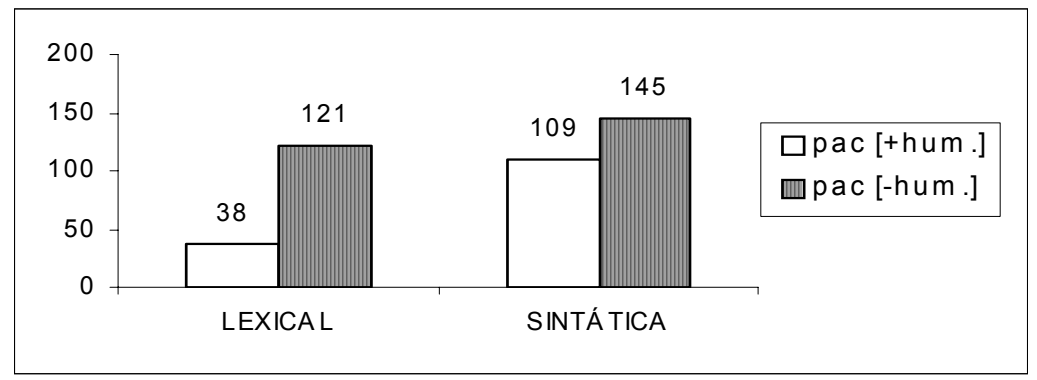

Fig. 9: Ocorrência de paciente [+/-humano] nas FVP de particípio (C2)

Considerando as variedades em conjunto, temos pacientes [-humano] em $64,4 \%$ das incidências e, uma vez mais, ratifica-se a tendência observada no PB e no Espanhol. 


\section{III.3.2.2. PACIENTE TEMA vs. REMA}

Do ponto de vista das funções pragmáticas, os dados do corpus C1 (figura 10) revelaram que o paciente ocorre majoritariamente como tema (83\% do total) nas FVP de particípio (lexicais e sintáticas).

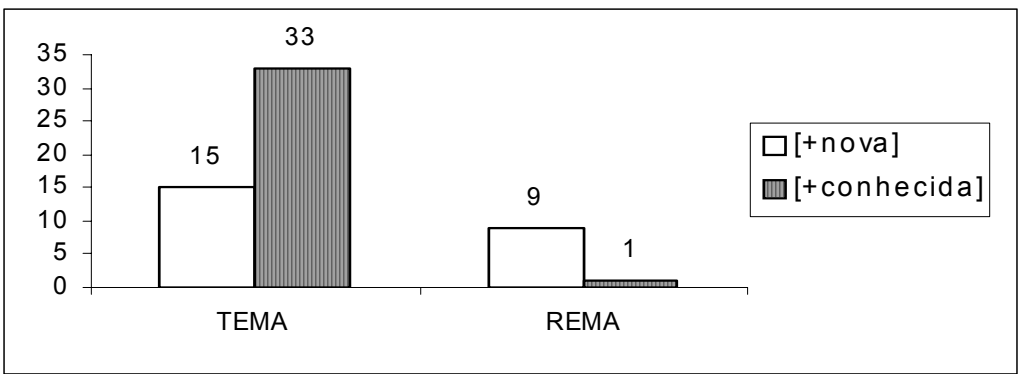

Fig. 10: Ocorrência de paciente TEMA/ REMA nas FVP de particípio (C1)

Assim como no PB e no Espanhol, a maioria dos pacientes TEMA possui o traço [+conhecida] para a informação veiculada. Isso ocorre em $69 \%$ dos casos:

(29) El tiburón fuiste, entonces, de encuentro a la isla y fuera del agua cansó y fue carregado por Francisco que ha se tornado muy famoso con la historia. (C1: I2.A.2)

Os pacientes REMA também seguem a tendência observada no PB e no Espanhol: predomina o traço [+nova] para a informação fornecida $(90 \%$ das ocorrências), conforme o exemplo abaixo:

(30) Así que me gustaría dejar bien claro mis protestos y también solicitar que me sea restituída una importancia en dinero, que sirva para pagarme los prejuízos que tuve, a que tengo derecho, por ter sido ludibriada. (C1: A1.7)

Em C2 (figura 11), os pacientes tema foram maioria, embora não de forma categórica como em C1. Totalizaram 58\% das observações, com supremacia do traço [+conhecida] para a informação veiculada $(77 \%)$, nas variedades lexical (31) e sintática (32):

(31) Emilio Martin Valdez es un hombre muy gordito y extraño, tiene bigote, una voz roca y un rostro de pocos amigos. (...) Una cicatriz en su cuello haz de ello una persona muy temida por todos, resultado de un cambio de tiros con traficantes del barrio de Cuesta Azul en Cali, Colombia. (C2: EC101442) 
(32) Mi madre se llama $\underline{\text { Rita. }}$ Ella nació en la provincia de Paraiba en 1933. Su madre murió un año después, por eso fue educada por sus abuelos. (C2: EB200881)

Para os pacientes rema, C2 repetiu os resultados de C1: predominou o traço [+nova] para a informação veiculada (94\%), nas variedades lexical (33) e sintática (34):

(33) No hubo nenguna novidad registrada, sólo las rosas gris en llano de piedras y el cielo rojo veinticuatro horas (en el tiempo de la Tierra). (C2: EB200312)

(34) Vuelve a su casa a las ocho o más, porque siempre encuentra una rica que quiere ser atendida sin marcar hora. (C2: EC101472)

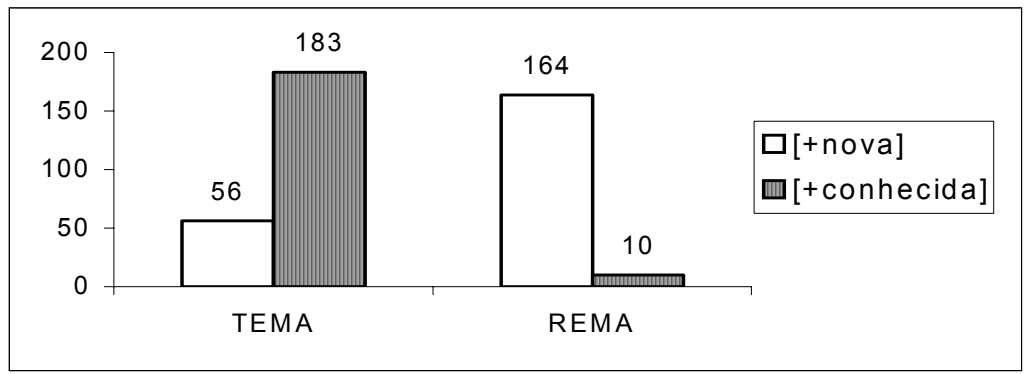

Fig. 11: Ocorrência de paciente TEMA/ REMA nas FVP de particípio (C2)

\section{III.3.3. A função das FVP}

Em C1 e C2, analiso a função das FVP a partir dos resultados referentes ao estatuto pragmático dos SN/agente e SN/paciente. As observações para o SN/agente nos dois corpora estão resumidas na tabela 13.

\begin{tabular}{|l|l|c|c|c|c|}
\hline \multirow{2}{*}{ SNIAGENTE } & \multicolumn{2}{c|}{ C1 } & \multicolumn{2}{c|}{ C2 } \\
\cline { 3 - 6 } \multicolumn{2}{|c|}{} & INCIDÊNCIAS & $\%$ & INCIDÊNCIAS & $\%$ \\
\hline PRESENÇA & 23 & 40 & 90 & 22 \\
\hline \multirow{3}{*}{ AUSÊNCIA } & TOTAL & 35 & 60 & 323 & 78 \\
\cline { 2 - 6 } & REF. ANTERIOR & 14 & 40 & 55 & 17 \\
\cline { 2 - 6 } & INFERÊNCIA & 4 & 11,4 & 86 & 26,6 \\
\hline
\end{tabular}

Tab. 13: Presença e ausência do SN/agente nos corpora

Conforme já comentado em III.3.1.1. , a tendência nos dois corpora foi a incidência de FVP [-agente] (60\% em C1 e 78\% em C2). Nas FVP com agente 
( $40 \%$ em C1 e 78\% em C2), este aparece como REMA, na maioria dos casos com o traço [+nova]. Portanto, pode-se concluir que o papel desempenhado pelas FVP em C1 e C2, do ponto de vista das funções pragmáticas, é destituir - SN/agente da posição temática (inicial): essa entidade ou é suprimida da construção (caso mais freqüente) ou aparece na posição final, remática, geralmente associada ao traço [+nova]. Resumindo, é o que Duarte (1990:163) define como detematização do agente.

As informações concernentes ao estatuto pragmático do paciente estão na tabela 14.

\begin{tabular}{|c|l|c|c|c|c|}
\hline \multicolumn{2}{|c|}{ SN/PACIENTE } & \multicolumn{2}{c|}{ C1 } & \multicolumn{2}{c|}{ C2 } \\
\cline { 3 - 6 } & INCIDÊNCIAS & $\%$ & INCIDÊNCIAS & $\%$ \\
\hline \multirow{2}{*}{ TEMÁTICO } & {$[+$ conhecida] } & 33 & 69 & 183 & 77 \\
\cline { 2 - 6 } & {$[+$ nova] } & 15 & 31 & 56 & 23 \\
\hline \multirow{3}{*}{ REMÁTICO } & {$[+$ +conhecida] } & 1 & 10 & 10 & 6 \\
\cline { 2 - 6 } & {$[+$ nova] } & 9 & 90 & 164 & 94 \\
\hline
\end{tabular}

Tab. 14: Estatuto pragmático do SN/paciente nos corpora

Nos dois corpora, o rebaixamento ou supressão do SN/agente (detematização) tem como conseqüência o alçamento do $\mathrm{SN} /$ paciente à posição temática - é o processo de tematização do paciente, segundo definição encontrada em Duarte (ibid.). De fato, conforme III.3.2.2., a tendência em C1 e C2 foi a ocorrência de pacientes TEMA (83\% em C1 e 58\% em C2), com traço [+conhecida] (69\% em C1 e $77 \%$ em C2). As poucas incidências de pacientes REMA (10\% em C1 e 6\% em C2) possuem majoritariamente o traço [+nova] (90\% em C1 e $94 \%$ em C2).

A detematização do agente e a tematização do paciente também ocorrem no PB e no Espanhol como principais funções das FVP de particípio.

Aqui concluo a apresentação dos resultados observados nos corpora. Por questões de organização, transfiro a análise e discussão desses resultados para o seguinte capítulo. 
CAPÍTULO IV

Análise dos resultados

\section{IV.1. Sobre o caráter marcado das FVP}

Conforme comentado no capítulo II (seção II.3.), o aplicativo WordList (WordSmith Tools, ibid.), quando acionado, produz três janelas na tela do computador: uma lista das palavras do corpus em ordem alfabética $(A)$, outra por ordem de freqüência $(F)$ e a terceira contendo estatísticas acerca dos dados do corpus (S). Dentre outras informações, como o seu número de formas (types, ibid.) e itens (tokens, ibid.), a lista $S$ também fornece o total de sentenças do corpus. Dessa forma, por já ter o levantamento das FVP em C2, é possível calcular o percentual dessas construções com relação ao total nos subcorpora e no corpus como um todo ${ }^{82}$. A tabela 15 mostra esses resultados.

\begin{tabular}{|c|c|c|c|c|c|c|}
\hline \multirow{2}{*}{ SUBCORPORA } & \multirow{2}{*}{$\begin{array}{c}\text { TOTAL } \\
\text { SENTENÇAS }\end{array}$} & \multirow{2}{*}{ ATIVAS } & \multicolumn{2}{|c|}{ FVP ( - se) } & \multicolumn{2}{|c|}{ FVP ( + se) } \\
\cline { 4 - 7 } & & TOTAL & $\%$ & TOTAL & $\%$ \\
\hline B1 & 3.212 & 3.146 & 66 & 2,05 & 69 & 2,15 \\
\hline B2 & 2.034 & 1.939 & 95 & 4,67 & 109 & 5,36 \\
\hline I1 & 754 & 684 & 70 & 9,28 & 80 & 10,61 \\
\hline I2 & 701 & 627 & 74 & 10,56 & 93 & 13,27 \\
\hline A1 & 523 & 458 & 65 & 12,43 & 82 & 15,68 \\
\hline A2 & 427 & 384 & 43 & 10,07 & 60 & 14,05 \\
\hline TOTAL & 7.651 & 7.238 & 413 & 5,4 & 493 & 6,44 \\
\hline
\end{tabular}

Tab. 15: Percentual das FVP nos subcorpora e no corpus total (C2)

A partir da figura 26, pode-se constatar a baixa produção das construções passivas com respeito às ativas. Considerando somente as FVP de particípio

\footnotetext{
${ }^{82}$ Não fiz o mesmo para C1 por não dispor de todos os textos desse corpus na íntegra; de algumas produções só destaquei os fragmentos que continham FVP, não sendo possível, portanto, levantar com mais exatidão o total de construções ativas e de passivas.

${ }^{83}$ Nesta coluna, disponibilizo os totais sem incluir as construções com se, ficando apenas com as FVP de particípio (sintáticas e lexicais). Na coluna seguinte (FVP + se) incorporamos as construções com se (incluídas também as indefinidas). Os comentários acerca desses totais e percentuais estão no corpo do texto.
} 
(FVP (-se)), por subcorpora, o percentual mais elevado é de $12,43 \%$ (A1); o total para a categoria é de apenas $5,4 \%$.

Incorporando-se as construções com SE (FVP (+se)), vai haver pequenos acréscimos nos percentuais dos subcorpora (maiores para 12, A1 e A2), obtendo-se no total uma porcentagem de $6,44 \%$ de FVP. Porém, é preciso deixar claro que integramos à categoria todas as construções com se, incluídas as INDEFINIDAS (ver IV.2.); portanto, nesse grupo, caso pudéssemos separar as construções passivas das impessoais, o percentual de FVP (+se) seria inferior ao valor encontrado ${ }^{84}$. De toda forma, o percentual de FVP no corpus de aprendizes está dentro da faixa observada para o Espanhol e para o PB: um valor compreendido entre 0 e $10 \%$. Portanto, pode-se afirmar que as FVP também são construções marcadas na produção dos aprendizes.

\section{IV.2. Sobre as preferências dos aprendizes}

Conforme já mencionado em III.2., foi notória a preferência dos aprendizes pelas FVP de particípio: nos dois corpora investigados, as FVP de particípio (lexicais e sintáticas, juntas) atingem uma porcentagem em torno de $80 \%$ do total. Essa preferência pelas FVP de particípio é a mesma observada nos trabalhos de Duarte (1990) e Moino (1989) para o PB, embora com diferentes graus: em Duarte (ibid.) os percentuais de FVP de particípio e FVP pronominais são de $51,7 \%$ e $48,3 \%$, portanto, muito próximos; em Moino (ibid.), temos percentuais de $67,7 \%$ para as FVP de particípio e $32,3 \%$ para as FVP pronominais $^{85}$. Portanto, podemos considerar que, na produção em língua espanhola dos aprendizes, a preferência pelas FVP de particípio segue a tendência verificada no PB. Nesse sentido, a produção dos aprendizes distancia-se do Espanhol, para o qual a preferência é marcadamente pelas

\footnotetext{
${ }^{84}$ Sobre o maior percentual de FVP apresentado por I2, A1 e A2, é preciso levar em conta a extensão desses subcorpora, inferior à dos demais: o subcorpus B1 (mais extenso, com 62.376 palavras), por exemplo, é 3 vezes maior que I2, 4 vezes maior que A1 e 6 vezes maior que A2; tivessem os subcorpora aproximadamente o mesmo tamanho, haveria talvez mais equilíbrio no cálculo dos referidos percentuais. ${ }^{85}$ Os percentuais são referentes à modalidade escrita. Para maiores informações, ver I.4.2.
} 
FVP pronominais ${ }^{86}$. A seguir, analiso alguns fatores que possivelmente explicam as preferências dos aprendizes pelas FVP de particípio na sua produção escrita.

\section{IV.2.1. A ordem SV na produção dos aprendizes}

Para as FVP de particípio, a ordem SV foi a predominante nos dois corpora, tendo atingido 96\% das ocorrências em C1 e 95\% em C2 (ver tab. 16). Apareceu inclusive em construções nas quais a ordem VS, ao menos em tese, a partir do que afirmam grande parte dos trabalhos consultados, seria a preferida no Espanhol, como em:

(1) ¿Los ataúdes fueron entregues? (C1: I2.C.6) (alternativas: 1. ¿Se entregaron/han entregado los ataúdes? ; 2. ¿Entregaron/han entregado los ataúdes? )

Estudos comprovam que a ordem dos constituintes no PB é consideravelmente mais rígida que em outras línguas românicas, aqui incluindo-se o Espanhol ${ }^{87}$. Kato (apud González: 1994) mostra que o enfraquecimento da flexão afeta a liberdade da ordem dos constituintes no PB, que apresenta baixa inversão de sujeito em estruturas transitivas ( $O$ que queriam esses dois?/ O que esses dois queriam?) e limita as inversões às estruturas intransitivas (Chegaram meus alunos ${ }^{88}$ ).

\begin{tabular}{|c|c|c|c|c|c|}
\hline NÍVEL & FVP & \multicolumn{2}{|c|}{ ORDEM SV } & \multicolumn{2}{c|}{ ORDEM VS } \\
\cline { 3 - 6 } & PARTICIPIO & QUANT. & $\%$ & QUANT & $\%$ \\
\hline B1 & 66 & 65 & 98,5 & 1 & 1,5 \\
\hline B2 & 95 & 92 & 96,8 & 3 & 3,2 \\
\hline I1 & 70 & 59 & 84,3 & 11 & 15,7 \\
\hline I2 & 74 & 73 & 98,6 & 1 & 1,4 \\
\hline A1 & 65 & 63 & 97 & 2 & 3 \\
\hline A2 & 43 & 41 & 95,3 & 2 & 4,7 \\
\hline TOTAL & 413 & 393 & 95,1 & 20 & 4,9 \\
\hline
\end{tabular}

Tab. 16: Ordem SV / VS nos subcorpora (C2)

\footnotetext{
${ }^{86}$ Ver os comentários sobre Barrenechea \& Manacorda de Rosetti (1979) e Kovacci (1977), em I.4.2.

${ }^{87}$ É o caso dos estudos de Kato (1987) e Galves (1993), comentados por González (1994).

${ }^{88}$ Exemplos da autora (ibid.: 240).
} 
Essa maior rigidez característica do PB provoca efeitos na produção dos aprendizes de E/LE, conforme pudemos verificar em nossa amostra. Em C1, na interpretação de um texto sobre os jogos na cultura grega, perguntava-se aos alunos qual era a diferença entre o jogo humano e o de outros mamíferos. Os alunos formularam respostas a partir do seguinte fragmento do texto:

El juego ha sido a través de la historia una de las herramientas instintivas más poderosas de aprendizaje y se presenta en infinidad de especies de mamíferos que de manera espontánea ensayan diferentes formas de supervivencia, ubicación y aceptación dentro de un grupo, que les permite en el futuro ser el líder dentro de un clan, manada o tribu. Es, por tanto, natural que el animal humano haya dispuesto beber de esta eterna fuente creativa para el desarrollo de estados culturales más elevados. El juego humano, como cualquier fenómeno de la cultura, no se trasmite genéticamente, sino por la educación. [Adaptación de www.colombia.com]

A maior parte dos alunos usou a frase em negrito (na qual aparece uma construção com se: ... no se trasmite genéticamente...) como resposta à questão, utilizando-a tal como aparece, ou com algumas variações/acréscimos. Entretanto, em $58 \%$ das respostas foram usadas outras construções:

(2) Los animales eran trenados para el juego y cuando vencían eran lider dentro de un clan, manada o tribu. Ya los humanos son distinguidos por toda la humanidad y son vistos como los mejores y como héroes. (C1: I2.C.1)

(3) El juego humano es un fenómeno cultural, no es trasmitido geneticamente. (C1: I2.C.1)

(4) El animal tiene presente el instinto que es la manera de supervivencia. Pero el humano además de la trasmisión genética, tiene también la educación. (C1: I2.C.7)

Desse total, 33\% dos alunos utilizaram a FVP sintática, como em (2) e (3). Recursos como a nominalização também apareceram, caso de (4), no qual se substitui a construção com pronome por uma expressão nominal ${ }^{89}$ (el juego se trasmite genéticamente $\rightarrow$ la trasmisión genética del juego). A julgar pelas respostas, diríamos que é como se houvesse uma tendência a rejeitar as construções com se, mesmo quando dadas "de bandeja", prontas para o uso: haveria talvez uma resistência dos aprendizes ante uma estrutura pouco

\footnotetext{
${ }^{89}$ Comentarei esse procedimento mais adiante.
} 
habitual em L1, que os obrigaria a reformular a expressão numa ordem mais familiar - leia-se ordem SV ${ }^{90}$.

De fato, na pesquisa de González (1994: 328) o percentual da ordem SV foi de $97,5 \%$ das ocorrências, contra $2,5 \%$ da ordem VS. Segundo a autora, esses resultados demonstram que a ordem SV é a preferencial na gramática dos aprendizes de E/LE, além de comprovar o lugar preponderante que tem o sujeito no enunciado. Para ilustrar essas afirmações, cita exemplo extraído de um comentário de texto (um conto do argentino Roberto Arlt, intitulado "Del que no se casa") feito por um aluno de nível avançado (ibid.: 329). O estudante transcreve parte da fala da personagem do conto e, em seguida, a reformula:

(5) Él dice que "se podía esperar otro ascenso más", es decir, otro ascenso se podría ser esperado.

Estamos diante de uma estrutura não prevista no Espanhol, na qual se superpõem uma construção com clítico e uma FVP sintática. Conforme a autora, o aluno parece ver-se obrigado a parafrasear a construção com se ${ }^{91}$ no intuito de restaurar a ordem que supõe familiar ao leitor (com anteposição do sujeito ao verbo). Concordo com essa afirmação e, ademais, identifico um processo de tematização presente no exemplo: o aluno promove à posição inicial um dos elementos presentes na frase do conto (otro ascenso), por considerá-lo o ponto de partida de seu comentário escrito, e utiliza uma FVP sintática (com sujeito anteposto ao verbo) para tematizá-lo.

Em sua pesquisa, ao comentar a consolidação da ordem SV no PB, González (ibid.) destaca a relevância do sujeito (quase sempre realizado lexicalmente) e a forte relação que este mantém com o tema (que cada vez mais se confunde com o sujeito no PB) como aspectos marcantes no processo. Neste trabalho, os resultados das análises dos corpora mostram que é essa ordem (e essa coincidência entre sujeito e tema) que os aprendizes, apoiando-

\footnotetext{
${ }^{90}$ Entretanto, não se pode descartar a interferência do contexto nesse caso: lembremos que as respostas surgiram numa atividade de avaliação, no ambiente de instrução formal. E na escola são muito comuns as paráfrases, sobretudo em interpretações de textos: quando solicitado nessa situação, muitas vezes o aluno julga que tem que dizer o mesmo de forma diferente — seja com outras palavras, seja com as mesmas do texto numa estrutura distinta.

${ }^{91}$ O curioso é que o aluno mantém o se na estrutura parafraseada. González (1994: 329) atribui o fato à consciência, por parte desse aprendiz, do forte emprego que tem o referido clítico em Espanhol.
} 
se na língua materna, utilizarão, talvez como um modo de obter os efeitos pretendidos, na sua produção em Espanhol - e que traz como uma das conseqüências a maior incidência de FVP sintáticas.

\section{IV.2.2. A questão pronominal}

A pouca incidência das construções pronominais (FVP ou indefinidas) em C1 $(19,4 \%)$ e C2 (16,2\%) (ver capítulo III, tabela 12) atesta sua escassa produção pelos aprendizes. Conforme González (1994:372s), essa baixa produtividade reflete o fenômeno que vem ocorrendo na língua materna desses estudantes: a perda dos clíticos, dentre os quais o "se" ${ }^{92}$. Na amostra da pesquisadora, os percentuais das FVP estão próximos aos verificados para C1 e C2: as FVP sintáticas atingiram 88\% (ibid.:393), contra $12 \%$ de FVP pronominais.

Segundo meus dados, a freqüência das construções com se tende a aumentar com a maior exposição dos aprendizes ao input, sobretudo a partir das 90 horas de instrução formal (do nível Intermediário I em diante). Porém, em momento algum a hegemonia das FVP de particípio é posta em risco, conforme se mostrou nas tabelas e gráficos (ver capítulo III, figuras 2 e 3). Por um lado, pode-se detectar nesse aumento a marca da instrução formal, uma vez que a partir desses níveis os aprendizes foram expostos às expressões impessoais de possibilidade (se + poder na $3^{\text {a }}$ pessoa + infinitivo), necessidade (se + buscar/necesitar/requerer/pedir na $3^{\text {a }}$ pessoa), recomendação (se + recomendar na $3^{\text {a }}$ pessoa), aconselhamento (se + deber na $3^{\text {a }}$ pessoa + infinitivo), pedido/ordem (se + pedir/ordenar/exigir na $3^{a}$ pessoa), conforme os exemplos:

(6) En las dos situaciones, se puede perceber que todos están felices, pero em la primera tal vez porque tenga adultos, todos están más comportados. (C2: EC300214)

(7) No es necesario experiencia anterior, sólo se requiere buena capacidad de comunicación. (C2: ED400281)

\footnotetext{
${ }^{92}$ A pesquisadora comenta o fenômeno de forma detalhada para o PB e discute seus efeitos na produção dos brasileiros em Espanhol, incluídas as construções passivas.
} 
(8) ¿Cuál es el horario que se debe cumprir? (C2: ED400701)

Por outro lado, embora em menor número, essas construções apareceram em todos os níveis, do $\mathrm{B} 1$ ao $\mathrm{A} 2$, antes mesmo de serem objeto de explicitação formal em cursos, o que de certa forma relativiza o peso do ensino formal. Caso interessante foi a incidência em C2 de construções de infinitivo com sentido passivo ${ }^{93}$, com pronome:

(9) A mi me gustó mucho visitar Ouro Preto, una ciudad antigua, con muchas histórias y lugares encantadores de se conocer. (C2: EB200284)

(10) Pero cuando miramos las fotos en el ordenador nos quedamos surpresos y aflitos. Sólo había piedras y más piedras para se estudiar. (C2: EC201152)

(11) Él no tiene su oficina particular. Cuando hay alguno caso a se resolver, generalmente él se queda en la casa onde hay ocurrido el crimen. (C2: ED101722)

Essas construções com pronome são pouco produzidas no Espanhol. Uma consulta no Google Espanha para a construção problema a solucionar forneceu 17.300 ocorrências; a alternativa problema a solucionarse (com pronome) teve apenas 9 incidências, ficando abaixo de problema a ser solucionado (41 casos). Pesquisa semelhante foi feita no Google Brasil, para o $\mathrm{PB}$, que forneceu 84 ocorrências para problema a se resolver, 7 para problema a ser resolvido, 2 para problema a resolver, e nenhuma para problema a resolver-se. No PB, portanto, o número de incidências da construção com "se" proclítico (problema a se resolver) é razoável. E como classificar a expressão? Pode-se identificar nela um sentido passivo; porém, a freqüência ínfima da correspondente problema a ser resolvido favorece a interpretação do exemplo como uma construção indeterminada. Conforme Bagno $(2000)^{94}$, a base verbal (resolver) seleciona um sujeito com traço semântico [+animado], de caráter genérico, codificado na sintaxe pelo clítico "se". Igualmente, a posição préverbal do "se" reflete a ordem Sujeito-Verbo (SV), predominante no PB, e reforça a leitura desse pronome como sujeito da expressão. Portanto, o caráter

\footnotetext{
${ }^{93}$ Para detalhe dessas construções, ver exemplos de Mendikoetxea no capítulo I (p. 20 e seguintes).

${ }^{94}$ Ver capítulo I, p. 39 e seguintes.
} 
nominativo do clítico no $\mathrm{PB}^{95}$, assim como a maior rigidez na ordem SV para essa língua, produzem efeitos na produção escrita dos aprendizes em Espanhol, conforme se vê nos exemplos (9), (10) e (11).

Há outro aspecto, referente à questão pronominal, que poderíamos relacionar à maior ocorrência de FVP sintáticas na produção escrita dos aprendizes em língua espanhola: a pressão da norma culta do PB. Partamos do seguinte exemplo da amostra:

(12) (...)Fuimos recibidos por muchos y variados insectos que paseaban tranquilamente y nos invitaban a bañarnos con ellos en el charco que era la piscina climatizada. (C1: A1.2)

No Espanhol, é muito possível que (12) aparecesse na forma ativa, devido ao uso corrente dos clíticos (sobretudo em próclise) e à maior flexibilidade na ordem dos constituintes que se observa nessa língua:

(13) (...) $\underline{\text { Nos }}$ recibieron muchos y variados insectos (...)

Os dois aspectos mencionados fazem com que (13) seja mais palatável no Espanhol ${ }^{96}$. No PB não é exatamente assim: por um lado, a ordem dos constituintes nessa língua é mais rígida que no Espanhol, privilegiando o sujeito anteposto ao verbo (SV), conforme já comentado em IV.2.1.; por outro lado, as gramáticas normativas do PB e os manuais de estilo condenam o uso dos pronomes clíticos como introdutores de enunciados. No último caso, a norma, embora infringida a todo instante na oralidade e na escrita informal, costuma ser observada freqüentemente em elocuções formais e sobretudo na escrita. Uma versão de (13), segundo a norma, poderia ser:

(14) (...) Receberam-nos muitos e variados insetos que passeavam tranquilamente $e$ nos convidavam a tomar banho com eles (...)

\footnotetext{
${ }^{95}$ Segundo Bagno (ibid.), os falantes do PB só admitem o "se” como acusativo em construções reflexivas, com sujeitos normalmente [+animados] ( $O$ artista olhou-se no espelho.). Com sujeitos [-animados], é freqüente o apagamento do "se" (A porta fechou. / O vaso quebrou.). A perda desse "se" intransitivador é uma das características presentes no PB, constituindo, segundo Kato \& Taralo (1986, apud GONZÁLEZ, 1994:281) um dos fatos que apontam uma mudança em curso, que demonstra, por outro lado, uma "rejeição pelos clíticos" (clitic rejection).

${ }^{96}$ Aqui cabe um esclarecimento: a sentença passiva produzida pelo aprendiz está bem construída e pode ser perfeitamente interpretada por qualquer hispanofalante. Nela, o uso da passiva sintática — por não refletir a ordem habitual do Espanhol — destaca a ironia do enunciado e causa maior impacto no leitor. Daí a importância de não prender-se unicamente à estrutura morfossintática dos enunciados, e levar em conta seus aspectos pragmáticos.
} 
Entretanto, a construção acima soa pesada e pedante aos ouvidos dos brasileiros, mesmo no discurso escrito ${ }^{97}$. A versão com sujeito anteposto e clítico em próclise tampouco funciona para o exemplo, pois a extensa oração de relativo (em aposição ao sujeito) ocasionaria problemas de gramaticalidade:

(15) ? (...) Muitos e variados insetos que passeavam tranquilamente $e$ (...) nos receberam.

O uso de uma FVP sintática resolveria o impasse:

(16) (...) Fomos recebidos por muitos e variados insetos que passeavam tranquilamente (...)

Diante do exposto, é possível que o mesmo processo, condicionado pela norma culta do PB, esteja presente na produção escrita dos aprendizes.

$\mathrm{O}$ último aspecto que relaciono à baixa incidência de FVP pronominais nos corpora analisados é a tematização ${ }^{98}$. No Espanhol, a tematização mais freqüente ocorre por meio dos clíticos, segundo a estrutura complemento direto tematizado + clítico duplicado + verbo ativo:

(17) A Miguel lo despidió el director.

No Espanhol, caso quiséssemos apagar o agente em (17), poderíamos reescrevê-lo como:

(18) A Miguel lo despidieron.

As construções como (18) foram definidas por Lorenzo (1980:20) como impersonales activas. Outra possibilidade de que dispõe o Espanhol para tematizar é a passiva perifrástica, embora, segundo os estudos consultados, seu uso seja menos freqüente ${ }^{99}$ :

(19) Miguel fue despedido (por el director).

\footnotetext{
${ }^{97}$ Entretanto, reitero a importância de ater-se também aos aspectos pragmáticos do enunciado: se a intenção do autor é a ironia, a construção do exemplo, com pronome enclítico e sujeito posposto, funciona perfeitamente.

${ }_{98}^{98}$ Para definição do termo, ver nota 41 (capítulo I).

${ }^{99}$ Conforme já comentamos no capítulo I, as passivas perifrásticas e lexicais são mais representativas nos gêneros textuais associados à informação, especialmente aqueles presentes nos meios de comunicação escrita (jornais, revistas, páginas web, folhetos, etc.).
} 
Tematizações nos moldes de (17) e (18), no PB, só ocorreriam em registros mais coloquiais, próprios da linguagem oral, e ainda assim o pronome repetido (de realização lexical facultativa) seria tônico e posposto ao verbo:

(20) O Miguel, o diretor despediu ele. / O Miguel, o diretor despediu.

(21) O Miguel, despediram ele. / O Miguel, despediram.

O pronome tônico só viria antes do verbo numa FVP sintática:

(22) O Miguel, ele foi despedido ( pelo professor).

Em suma, o Espanhol pode tematizar: 1) por meio do deslocamento à esquerda do complemento direto (cf. (17) e (18)), sendo esta, segundo atestam alguns estudos, a preferência nessa língua; 2) por meio da FVP sintática (cf. (19)). Por outro lado, a rejeição do uso dos clíticos pelos brasileiros praticamente converte a FVP sintática no único recurso (ao menos na modalidade escrita) de que dispõe o PB para tematizar.

Passando à produção dos aprendizes, tomemos exemplos coletados dos corpora:

(23) El Sr. López es respectado por su profesionalidad pero hay quien le tenga mucha envidia. Juanito no es admirado por nadie, pero es muy gracioso y tiene muchos amigos. (C1: A2.A.1)

(24) Miguel es un muchacho muy querido por sus compañeros de trabajo (...) (C2: EA100372)

Para o enunciado em questão, conforme assinalam alguns estudos e dependendo do gênero em que a construção aparece, seria mais freqüente a tematização por meio do deslocamento à esquerda do complemento direto da construção ativa (Sr. López/ Juanito), ficando a posição original desse constituinte ocupada por um clítico (lo):

(25) Al Sr. López $\underline{\text { lo }}$ respetan por su profesionalidad pero hay quien le tenga mucha envidia. A Juanito no $\underline{\mathbf{l}}$ admira nadie, pero es muy gracioso y tiene muchos amigos.

(26) A Miguel lo quieren mucho sus compañeros de trabajo (...) 
Nos corpora de aprendizes, entretanto, foi computado apenas um exemplo com deslocamento do complemento direto:

(27) ¡No pienses que podés librarte así tan fácil de la cuestión! Lo que escuché no eran chismes, eso lo tengo por cierto, porque lo escuché de gente confiable. (C2: EF600075)

Mesmo nos casos em que normalmente os hispanofalantes utilizariam clíticos, foi freqüente o uso de FVP sintáticas:

(28) Estoy ahora con la señorita Maria. Su apellido es Sanches y es conocida como: "la santa". (C2: EA100614) [Su apellido es Sanches y la conocen como (...)]

A ausência quase total de enunciados como (25), (26) e (27) nos corpora são forte evidência de que tais construções são evitadas na produção escrita dos aprendizes brasileiros. Cf. González (1994), o evitamento (do inglês avoidance) é o fenômeno segundo o qual os aprendizes não produzem (ou produzem muito escassamente) determinadas estruturas da L2 por não tê-las incorporado - seja devido à falta de percepção, seja devido à não compreensão dessas construções. A pesquisadora considera que o evitamento está associado a uma visão seletiva da aquisição de L2. Liceras (1996: 238) refere-se ao fenômeno como inhibición, resenhando Smith:

(...) En la clasificación de errores que presenta [Smith], la inhibición se manifiesta en el uso de construcciones con las que los hablantes de L2 no se sienten cómodos y persisten hasta el tercer año de estudio del español. Las construcciones con subjuntivo, pasiva e impersonal con se, relativas y pronominales - que se consideran difíciles en las gramáticas del español — son las menos usadas en las composiciones de los estudiantes.

A duplicação e o deslocamento à esquerda constituem uma dificuldade para os aprendizes, porque tais recursos exigem o emprego de clíticos: cada vez menos usados no $\mathrm{PB}$, acabam constituindo uma área problemática na aquisição do Espanhol por brasileiros.

A essa dificuldade, pode-se acrescentar a necessidade de marcação do caso acusativo com a preposição $a$, no caso dos complementos diretos com traço [+humano] e [+específico] (ver exemplo (24)). O estudo de Yokota (2001) revelou que a marcação de caso - existente, porém de incidência insignificante no PB - ocorre de forma bastante irregular na produção escrita 
dos aprendizes brasileiros de $E / L E^{100}$. Portanto, para averiguar o fenômeno nos meus dados, levantei as ocorrências da preposição a relacionadas à tematização ${ }^{101}$. Como resultados, só obtive construções intransitivas com verbos de percepção sensorial (a mí me gustal a ella le encantal a él le parece, etc.); as construções transitivas (A Juan lo vi ayer) não apareceram, nem mesmo considerando-se a omissão da preposição $a$.

Portanto, o não uso de clíticos (ou seu uso muito escasso) pelos aprendizes brasileiros ocasionaria o evitamento (ou inibição) da tematização, via estruturas duplicadas e deslocamentos, favorecendo a tematização unicamente por meio das FVP sintáticas e sua conseqüente proliferação na produção escrita desses aprendizes em língua espanhola.

\section{IV.2.3. A nominalização}

\section{Consideremos os exemplos:}

(26) Ustedes me vendieron un viaje organizado, pero, nada de lo prometido fue verdad. (C1: A1.12)

(27) Exigimos de usted: a) la devolución de nuestro dinero; b) el reparo del coche, bien como la reposición de todo que le fue robado (...) (C1: A1.10)

Em (26), o particípio (prometido) fica nominalizado pelo emprego do determinante neutro 10 . A nominalização possibilita ao aprendiz eludir tanto construções ativas (... lo que nos prometieron...) como passivas/impessoais (... lo que se [nos] prometió.../ ... lo que [nos] fue prometido/ ... lo que [nos] había sido prometido...). O mesmo acontece em (27) com:

\footnotetext{
${ }^{100}$ Diz Yokota (ibid.: 126): "No que se refere ao uso da preposição a junto a objeto direto, a omissão é um erro fossilizado para muitos estudantes e a adição um erro menos freqüente. O uso da preposição de acordo com as normas da língua meta ocorre, mas não há um resultado único quanto a este uso; verificamos que os instrumentos de coleta de dados revelam informações diferentes de acordo com o tipo de coleta.” Na seqüência, conclui (ibid.): “A variação existente nos resultados das diferentes coletas demonstra que às vezes o uso da preposição a pelos estudantes pode corresponder, superficialmente, ao uso feito pelos que aprendem Espanhol como LM, mas que de fato não se trata da mesma competência. As razões que levam à utilização da estrutura em língua materna e língua estrangeira são diferentes, a começar pela forma de aquisição deste conhecimento.”

${ }^{101}$ A pesquisa foi feita com o programa WordSmith Tools (ver item II.3), para um subcorpus de C2: foram selecionadas, aleatoriamente, 20 produções de cada nível (do B1 ao A2), 160 no total. Como palavras de busca, utilizei A, AL, LO*, LA*, LE*. Após a filtragem de concordâncias, só restaram 177 ocorrências para A.
} 
1. Ia devolución de nuestro dinero: que nos devuelvan el dinero/ que se [nos] devuelva el dinerol que el dinero [nos] sea devuelto;

2. el reparo del coche: que nos reparen el cochel que se nos repare el coche/ que el coche [nos] sea reparado;

3. la reposición (...): que nos repongan (...)/ que se [nos] reponga (...)/ que [nos] sea repuesto (...)

Através dos exemplos desta seção, é possível ver que muitas vezes o aprendiz lança mão de estratégias simplificadoras para resolver os problemas - muitas vezes espinhosos - da enunciação em L2. Dentre essas estratégias, é talvez a nominalização que oferece mais possibilidades. Ela resulta da transformação de uma frase com verbo finito que, ao nominalizar-se, perde as marcas de tempo, aspecto e modo, e muitas vezes também deixa de explicitar o sujeito agente pela ação ou processo nominalizado ${ }^{102}$ (Ex.: a cidade foi invadida pelo exército inimigo durante a noite $\rightarrow$ a invasão da cidade [pelo exército inimigo] foi durante a noite). Por tais características, pode-se afirmar que a nominalização funciona de modo semelhante às passivas e às impessoais, transformando-se num mecanismo alternativo a essas construções na produção dos aprendizes em língua espanhola. Trata-se de um tema a ser aprofundado em estudos posteriores.

\footnotetext{
${ }^{102}$ Cf. comentário escrito da Prof ${ }^{\mathrm{a}}$ Mónica Zoppi-Fontana (UNICAMP), ao qual tive acesso através da Prof $^{a}$ Maite Celada (USP/FFLCH).
} 


\section{CONCLUSÕES}

Terminado o meu estudo sobre as construções passivas na produção escrita (em língua espanhola) de brasileiros aprendizes de E/LE, faço as seguintes observações finais, à guisa de conclusão:

\section{A hipótese assumida de que as FVP têm caráter marcado no Espanhol} e no PB foram endossadas pela maioria dos estudos que consultei para ambas as línguas. Dentre todos, porém, os únicos que trazem análises quantitativas são os de Barrenechea \& Manacorda de Rosetti (1979), para o Espanhol oral; Moino (1989), para o PB escrito e oral; e Duarte (1990), para o PB escrito. Os resultados levantados por Barrenechea \& Manacorda de Rosetti (ibid.) forneceram uma incidência de 97,82\% de construções ativas, contra apenas 2,18\% de passivas. Embora considerando a especificidade desse estudo, feito para a modalidade oral portenha, em função de tudo o que li sobre essa língua e de observações empíricas, penso que seria possível extrapolá-lo para a modalidade escrita e para as demais variantes da língua espanhola; haveria diferenças nesses percentuais, porém, a partir das referências consultadas, a hegemonia das construções ativas dificilmente seria revertida.

Para o PB, a análise de Moino (ibid.) forneceu surpreendentes $63,5 \%$ para as passivas e $36,1 \%$ para as ativas; os resultados de Duarte (ibid.), ao contrário, corroboram a preponderância das ativas (91\%) com relação às passivas (9\%). A explicação para resultados tão discrepantes provavelmente está na constituição dos corpora: Moino (ibid.) trabalhou apenas com um gênero textual (os editoriais de jornais e revistas), enquanto Duarte (1990) montou um corpus diversificado com textos científicos, jornalísticos e uma peça de teatro. Considero o resultado de Duarte (ibid.) mais de acordo com os demais estudos consultados para o PB, para os quais as passivas têm bem 
menos freqüência na língua. Por outro lado, o percentual encontrado por Moino (ibid.) para as FVP nos dá uma pista de que o gênero pode ser uma variável significativa numa análise semelhante; o elevado índice de FVP de particípio (sintáticas e lexicais) encontrado pela pesquisadora nos editoriais está de acordo com afirmação de alguns lingüistas (Romero Gualda, 1996; Fanjul, 1999) de que determinados gêneros textuais associados à informação, especialmente os presentes nos meios de comunicação escrita (jornais, revistas, páginas web, folhetos, etc.) favorecem o surgimento dessas construções. Em suma, independentemente da superioridade numérica das construções ativas em termos absolutos, é preciso considerar que há gêneros em que as passivas têm relevância.

2. A análise contrastiva das FVP no PB e no Espanhol (ver l.4) nos possibilitou observar que, efetivamente, há tendências comuns e assimetrias no uso dessas construções em ambas as línguas.

Sinteticamente, para a modalidade escrita:

2.1. O PB e o Espanhol apresentam preferências distintas: no PB predominam as FVP de particípio (sintáticas e lexicais), enquanto no Espanhol as FVP pronominais são mais abundantes. Dos $2,18 \%$ de construções passivas inventariados por Barrenechea \& Manacorda de Rosetti (1979) para o Espanhol portenho, $72 \%$ são FVP pronominais e $27 \%$ são FVP de particípio. Para o PB, Moino (1989) computou 43,2\% de FVP de particípio e $20,7 \%$ de passivas pronominais; Duarte (1990) obteve $62,8 \%$ de FVP de particípio e $37,2 \%$ de FVP pronominais.

\subsection{O PB e o Espanhol tendem a omitir o agente nas construções} passivas. Para $\mathrm{PB}$, a ausência do agente nas análises quantitativas foi de 67,2\% em Moino (ibid.) e $84,1 \%$ em Duarte (ibid.). Para o Espanhol, a pesquisa de Barrenechea \& Manacorda de Rosetti (ibid.) não registrou uma só ocorrência de agente; o mesmo ocorreu no estudo de Barbeito \& Miñones (2002) para as passivas pronominais. No trabalho de Miñones (2000) para as FVP de particípio, o percentual de construções sem agente (59\%) foi pouco superior ao das construções com agente (41\%); essa pequena margem pode 
ser explicada em função do corpus da pesquisadora, constituído de apenas notícias policiais - gênero que favorece a aparição de agentes, seja como informação nova, seja para contrastá-los com outros agentes no discurso.

\subsection{No PB e no Espanhol a tendência é que incidam pacientes com traço} semântico [-humano]. Para o PB, Moino (ibid.) obteve $88 \%$ de pacientes com o traço [-humano]. Para o Espanhol, Miñones \& Sánchez (ibid.) também encontraram pacientes majoritariamente [-humanos] nas FVP de particípio, com percentuais maiores ou menores em função do gênero; no caso das FVP pronominais, Barbeito \& Miñones (ibid.) contabilizaram 95\% de pacientes com traço [-humano] em seu corpus.

2.4. O PB e o Espanhol tendem a tematizar o paciente nas FVP de particípio (sintáticas e lexicais); nas FVP pronominais do Espanhol (não tenho dados do PB) a maioria dos pacientes é remática, veicula informação com traço [+nova] e está focalizada. Para $\circ \mathrm{PB}$, a análise de Duarte (ibid.) forneceu $89,6 \%$ de pacientes temáticos nas FVP de particípio; Moino (ibid.) obteve uma média de $55,4 \%$ de pacientes temáticos nessas construções $(78,7 \%$ nas sintáticas e $44,8 \%$ nas lexicais). Para o Espanhol, Miñones \& Sánchez (ibid.) obtiveram 100\% de pacientes em posição temática, nas FVP de particípio. A análise de Barbeito \& Miñones (ibid.) para as FVP pronominais obteve índices expressivos de SN/pacientes na função de rema $(78,3 \%)$, veiculando informação com traço [+nova] $(74,7 \%)$ e em posição focal $(74,7 \%)$.

2.5. Finalmente, nas FVP do PB e do Espanhol, a ausência majoritária do agente ou sua recodificação nos termos especificados por Duarte (ver I.3., p.40) nos permite definir a detematização do agente como função básica dessas construções nas duas línguas. Como funções secundárias, teríamos a tematização do paciente nas FVP de particípio e, para as FVP pronominais do Espanhol (cf. Barbeito \& Miñones, ibid.), a focalização do paciente e a veiculação de informação nova (rema). 
3. No que se refere aos corpora de aprendizes, as análises revelaram que:

3.1. Assim como no PB e no Espanhol, as FVP na produção dos estudantes são estruturas marcadas. Para o corpus $\mathrm{C} 2$, o percentual dessas construções foi inferior a $7 \%$ do total do corpus. Observou-se, igualmente, que a incidência de cada uma das construções (ativas, FVP sintáticas, FVP lexicais, FVP pronominais e indefinidas) foi proporcionalmente a mesma nos dois corpora, apesar das diferenças de extensão entre eles.

3.2. As FVP de particípio (sintáticas e lexicais) foram maioria nos dois corpora, com percentuais de $79,4 \%$ (C1) e $83,8 \%$ (C2), resultados que aproximam a produção dos aprendizes do PB e a afastam do Espanhol.

3.3. As FVP de particípio, nessa produção em língua estrangeira, têm em comum com o PB e o Espanhol a tendência à omissão do agente $(60 \% \mathrm{em}$ C1; 78\% em C2); a preferência por agentes [+humano] (61\% em C1; 67\% em C2); a preferência por pacientes [-humano] (64\% em C1; 64,4\%), temáticos ( $83 \%$ em C1; $58 \%$ em C2) e referentes à informação com traço [+conhecida] (69\% em C1; 77\% em C2); a detematização do agente e a tematização do paciente como principais funções.

4. No Espanhol, as construções com clíticos são as mais produtivas; daí a saliência das FVP pronominais, além da tematização/detematização por meio de clíticos, o que reduz a incidência de FVP de particípio nessa língua. No PB, ao contrário, mudanças que ocorreram/ vêm ocorrendo no idioma consolidam sua preferência pelas FVP de particípio: o enfraquecimento da flexão, conforme já apontado, leva ao enrijecimento da ordem SV, ao protagonismo do sujeito e ao evitamento da tematização por meio do deslocamento do complemento direto à esquerda ou da duplicação; igualmente, a rejeição pelos clíticos (inclusive o "se") e determinadas regras da norma culta para sua colocação leva os lusofalantes brasileiros a produzir menos construções com pronomes, dentre as quais a FVP pronominal. A combinação desses fatores, no PB, converte a FVP sintática no principal recurso quando se trata de tematizar um constituinte ou detematizar outro 
numa construção transitiva. Portanto, tais fatores ajudariam a explicar a interferência da língua materna na produção de FVP, em língua espanhola, por aprendizes brasileiros: a rigidez da ordem dos constituintes e a perda dos clíticos no PB relacionam-se às transformações pelas quais passou/vem passando a língua como conseqüência de sua evolução; já a restrição ao uso de clíticos no início de enunciados, que tem bastante força na modalidade escrita, é de cunho normativo e se faz sentir sobretudo na escola - é um exemplo de como a "identidade lingüística escolar" (Orlandi, 1998) produz efeitos e pode permear a relação de um sujeito com a língua estrangeira que está aprendendo.

O peso da questão pronominal na produção das FVP corrobora a constatação de González (1994) de que os pronomes constituem uma área problemática na aquisição/aprendizagem do Espanhol por aprendizes brasileiros. Essa dificuldade leva-os a buscar outros caminhos: em alguns enunciados dos corpora, por exemplo, utiliza-se a nominalização como forma de apagar o agente do enunciado. Tal procedimento não foi o foco desta pesquisa, porém revelou-se uma alternativa eficaz às construções passivas e impessoais na produção dos aprendizes, o que justificaria seu aprofundamento em estudos posteriores.

\section{A diversidade das FVP, assim como sua preponderância em} determinados gêneros discursivos, já não comporta uma abordagem tradicional do tema nos cursos de E/LE para brasileiros. Em vez de pautar-se unicamente pelas diferenças de uso que têm essas construções no Espanhol e no PB, seria proveitoso beneficiar-se, também, dos usos que compartilham. É o caso, por exemplo, de estimular o emprego das FVP lexicais pelos aprendizes, nos gêneros em que essa variedade predomina em ambas as línguas: aqueles relacionados à informação. 
BIBLIOGRAFIA

\section{Referências bibliográficas}

ALARCOS LLORACH, Emilio. Estudios de gramática funcional del español. Madrid: Gredos, 1970. p.90-94, 124-132.

ARAÚJO JÚNIOR, Benivaldo J. de. Estruturas Passivas no Espanhol Escrito: um Estudo de Caso Utilizando a Lingüística de Corpus. Crop, São Paulo: Humanitas Publicações FFLCH/USP, n. 10, p. 261-277, 2004.

BARBEITO, Vanina; MIÑONES, Laura. Rasgos del Paciente en las construcciones pasivas con se. In: Actas del IX Congreso de la Sociedad Argentina de Lingüística (CD), 2002 (Córdoba).

BARRENECHEA, Ana M. ; MANACORDA DE ROSETTI, Mabel V. Estudios de gramática estructural. Buenos Aires: Paidós, 1969. p. 71-73.

. La voz pasiva en el español hablado en Buenos Aires. In: Estudios lingüísticos y dialectológicos. Buenos Aires: Hachette, 1979. p. 61-72.

BELLO, Andrés. Gramática de la lengua castellana. Madrid: EDAF, 1984. p. 151.

CAMACHO, Roberto G. Construções passiva e impessoal: distinções funcionais. Alfa, São Paulo, v. 44, p. 215-233, 2000.

CAMARA JR., Joaquim M. Princípios de lingüística geral. 7.ed. Rio de Janeiro: Padrão, 1977. p. 187-188.

CAMPOS, Héctor. Transitividad e intransitividad. In: BOSQUE, I.; Demonte, V. (Dir.) Gramática Descriptiva de la Lengua Española: Las construcciones sintácticas fundamentales; Relaciones temporales, aspectuales y modales. Madrid: Espasa, 1999, p. 1519-1574. (Gramática Descriptiva de la Lengua Española, 2). 
CANÇADO, Márcia. O Papel do Léxico em uma Teoria dos Papéis Temáticos. D.E.L.T.A, São Paulo, v. 16, n. 2, 2000. . Uma aplicação da teoria generalizada dos papéis temáticos: Verbos psicológicos. Revista do Gel, n. especial, 2002, p. 93-125. . Um estatuto teórico para os papéis temáticos. In: MÜLLER, Ana L. ; NEGRÃO, Esmeralda V. ; FOLTRAN, Maria José (Orgs.). Semântica formal. São Paulo: Contexto, 2003, p. 95-124.

DUARTE, Yara. As passivas do português e do inglês: uma análise funcional. D.E.L.T.A, São Paulo, v. 6, n. 2, p. 139-167, agosto 1990.

FANJUL, Adrián P. Espacio de la persona en la versión portugués-español: un problema de identidad discursiva. Estudos Acadêmicos Unibero, n.10. São Paulo, UNIBERO, 1999. p. 135-154.

FÁVERO, Leonor L.; KOCH, Ingedore G. V. Lingüística textual: Introdução. 5.ed. São Paulo: Cortez, 2000.

FERNÁNDEZ RAMÍREZ, Salvador. Gramática Española: El Verbo y la Oración. 2.ed. Madrid: Arco, 1986. p. 410- 429.

GILI GAYA, Samuel. Curso superior de sintaxis española. 12.ed. Barcelona: Bibliograf, 1978. p. 121-129.

GONZALEZ, Neide T. M. Cadê o pronome? -O gato comeu. Os pronomes pessoais na aquisição/aprendizagem do espanhol por brasileiros adultos. São Paulo, 1994. 451 f. Tese (Doutorado em Lingüística) — Faculdade de Filosofia, Letras e Ciências Humanas, Universidade de São Paulo.

ILARI, Rodolfo. Introdução à Semântica. São Paulo: Contexto, 2001. p. 131.

INDURSKY, Freda. A interpretação do clítico SE: uma fronteira entre sintaxe e discurso. Boletim da Associação Brasileira de Lingüística, n. 14. São Paulo, 1993. p. 243-251.

LÁZARO CARRETER, Fernando. Estudios de Lingüística. Barcelona: Crítica, 1891. p. 61-72. 
LORENZO, Emilio. Sobre el talante y el semblante de la lengua española. In: El español y otras lenguas. Madrid: SGEL, 1980. p. 17-22.

LICERAS, Juana M. La adquisición de las lenguas segundas y la gramática universal. Madrid: Síntesis, 1996. . On the specific nature of non-native grammars: the whys, whens, wheres and hows. In: FERNÁNDEZ-GONZÁLEZ, J.; DE SANTIAGOGUERVÓS, J. (Ed.) Issues in Second Language Acquisition and Learning. Universitat de València, vol. 6, p. 58-96, 1998.

MASSONI, Maria I. de O. ; MARTIM, Erotilde G. P. A passiva com verbo ser em português. In: BORBA, Francisco S. (Org.) Boletim do Curso de PósGraduação em Lingüística e Língua Portuguesa "Estudos de Sintaxe Portuguesa". Araraquara, UNESP, 1985. p. 40-51.

MATTE BON, Francisco. Gramática comunicativa del español. Madrid: Edelsa, 1992. v.1, p. 101.

MENDIKOETXEA, Amaya. Construcciones inacusativas y pasivas. In: BOSQUE, I.; Demonte, V. (Dir.) Gramática Descriptiva de la Lengua Española: Las construcciones sintácticas fundamentales; Relaciones temporales, aspectuales y modales. Madrid: Espasa, 1999, p. 1575-1629. (Gramática Descriptiva de la Lengua Española, 2).

MIÑONES, Laura. ; SÁNCHEZ, K. Condiciones de aparición de la VpdeFV sin Agente en el español escrito. In: Actas de las 1eras Jornadas de Lingüística "Beatriz Lavandera" (CD). Mar del Plata: Universidad Nacional de Mar del Plata, 1999. Las condiciones de aparición de la Voz Pasiva de Frase Verbal con ser en el español escrito. In: Actas del VIII Congreso de la Sociedad Argentina de Lingüística. Mar del Plata: Universidad Nacional de Mar del Plata, 2000. MOINO, R. E. L. Passivas nos discursos oral e escrito: No princípio era o verbo. E o verbo se fez adjetivo? Ou... O que estamos fazendo no oral! In: TARALLO, Fernando. (Org.) Fotografias Sociolingüísticas. Campinas: Pontes, 1989, p. 35-50. 
PONTES, Eunice. O Tópico no Português do Brasil. Campinas: Pontes, 1987. REAL ACADEMIA ESPAÑOLA. Banco de Datos (CREA) [on line]. Corpus de Referencia del Español Actual. < http://corpus.rae.es/creanet.html >. Acesso no período de 30/05/04 a 15/07/04, e em 17/10/06.

REAL ACADEMIA ESPAÑOLA. Esbozo de una nueva gramática de la lengua española. Madrid: Espasa Calpe, 1973.

SAID ALI, Manuel. Gramática Histórica da Língua Portuguesa. 7.ed. Rio de Janeiro: Acadêmica, 1971.

SAUSSURE, Ferdinand de. Curso de Lingüística Geral. Trad. Antônio Chelini, José Paulo Paes e Izidoro Blikstein. São Paulo: Cultrix, 1970. p. 130-141.

SERRANI, Silvana M. Uma análise discursiva do recurso da indeterminação de agente SE - verbo em espanhol, in: Estudos lingüísticos VIII - Anais de Seminários do GEL. Assis, UNESP - GEL, 1984. p. 147-157.

YOKOTA, Rosa. A marcação de caso acusativo na interlíngua de brasileiros que estudam o espanhol. São Paulo, 2001. 197f. Dissertação (Mestrado em Lingüística) — Faculdade de Filosofia, Letras e Ciências Humanas, Universidade de São Paulo. p.124-126

\section{Bibliografia geral}

BARALO, Marta. La adquisición del español como lengua extranjera. Madrid: Arco, 1999. p. 37-44.

CAMARA JR., Joaquim M. Dicionário de lingüística e gramática. 18.ed. Rio de Janeiro: Vozes, 1977.

CHARAUDEAU, Patrick; MAINGUENEAU, Dominique. Dicionário de Análise do Discurso. Trad. Fabiana Komesu (Coord.). São Paulo: Contexto, 2004. CRYSTAL, David. Dicionário de Lingüística e Fonética. Trad. Maria Carmelita Pádua Dias. Rio de Janeiro: J. Zahar, 1988. p. 168. 
DIK, Simon C. Methodological Preliminaries. In: The Theory of Functional Grammar. Dordrecht, Holland; Providence RI, U.S.A.: Foris Publications, 1989, p. 1-22.

DUBOIS, Jean et alii Dicionario de lingüística. Trad. de Barros, F. P. et alii. São Paulo: Cultrix.

GÓMEZ TORREGO, Leonardo. La impersonalidad gramatical: descripción y norma. 3.ed. Madrid: Arco, 1998. (Cuadernos de Lengua Española).

GUTIÉRREZ ORDOÑEZ, Salvador. Temas, remas, focos, tópicos y comentarios. Madrid: Arco, 1997. (Cuadernos de Lengua Española).

HALLIDAY, M. A. K. Estrutura e função da linguagem. In: LYONS, John (Org.) Novos horizontes em Lingüística. Trad. Geraldo Cintra. São Paulo: Cultrix, 1976. p. 134-160.

NEVES, Maria H. de M. A Gramática Funcional. São Paulo: Martins Fontes, 2001.

ORLANDI, Eni P. Funcionamento e discurso. In: A linguagem e seu funcionamento: as formas do discurso. São Paulo: Brasiliense, 1983. p. 105123.

. O que é lingüística? São Paulo: Brasiliense, 1986. Identidade lingüística escolar. In: SIGNORINI, Inês (Org.) Linguagem e identidade. Campinas: Mercado de Letras, 1998, p. 203-212. PEZATTI, Erotilde G. O Funcionalismo em Lingüística. In: MUSSALIM, Fernanda; BENTES, Anna C. (Org.) Introdução à Lingüística: Fundamentos Epistemológicos. São Paulo: Cortez, 2004, p. 165-218. (Introdução à Lingüística, 3).

PORTO DAPENA, José-Álvaro. Complementos argumentales del verbo: directo, indirecto, suplemento y agente. 3.ed. Madrid: Arco, 1997. (Cuadernos de Lengua Española).

RODRIGUES, André F. Como elaborar referência bibliográfica. São Paulo: Humanitas, 2003. 
ROMERO GUALDA, María V. El español en los medios de comunicación. 3.ed. Madrid: Arco, 1996. (Cuadernos de Lengua Española).

\section{Livros didáticos e paradidáticos consultados}

ANDRÉ, Hildebrando A. de. Gramática ilustrada. 5.ed. São Paulo: Moderna, 1997.

BECHARA, Evanildo. Moderna gramática portuguesa. 20.ed. São Paulo: Companhia Editora Nacional, 1976.

. Moderna gramática portuguesa. 37.ed. Rio de Janeiro: Lucerna, 1999.

CASTRO, Francisca. Uso de la gramática española: elemental. Madrid: Edelsa, 1996. . Uso de la gramática española: intermedio. Madrid: Edelsa, 1997. . Uso de la gramática española: avanzado. Madrid: Edelsa, 1997.

CERROLAZA, Matilde; CERROLAZA, Óscar; LLOVET, Begoña. Planet@ 1: Libro del alumno. 2.ed. Madrid: Edelsa, 1998. ; Planet@ 1: Libro de referencia gramatical. 2.ed.

Madrid: Edelsa, 1998.

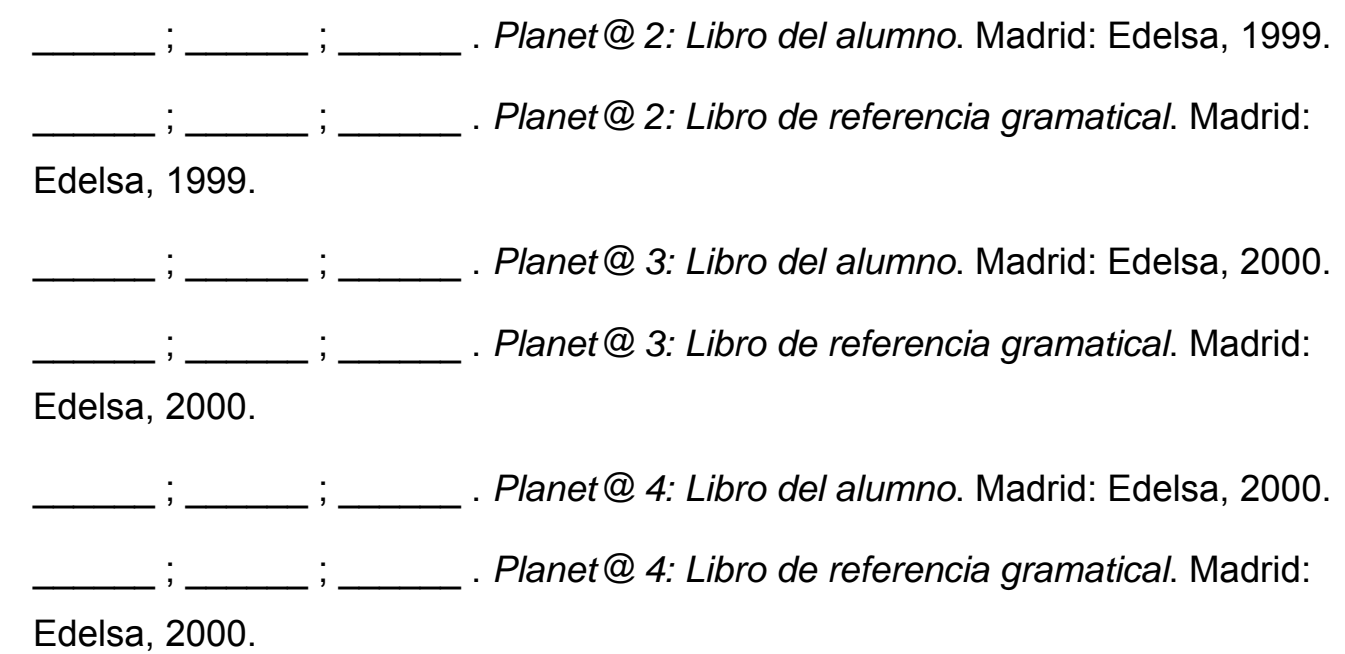

Edelsa, 2000. 
CEREJA, William R.; MAGALHÃES, Thereza C. Gramática: texto, reflexão e uso. 2.ed. São Paulo: Atual, 2004.

CUNHA, Celso. Gramática da língua portuguesa. 12.ed. Rio de Janeiro: FAE, 1990.

; CINTRA, Lindley. Nova gramática do português contemporâneo.

3.ed. Rio de Janeiro: Nova Fronteira, 2001.

DOMÍNGUEZ, Pablo.; BAZO, Plácido. Claves del Español: Gramática Práctica. Madrid: Santillana, 1994.

FARACO, Carlos E. ; MOURA, Francisco Marto de. Gramática nova. 14.ed.

São Paulo: Ática, 2004.

KOVACCI, Ofelia. Castellano 3. Buenos Aires: Hiremul, 1977. p. 144-149.

LUFT, Celso P. Moderna gramática brasileira. São Paulo: Globo, 1996.

NETO, Pasquale C.; INFANTE, Ulisses. Gramática da língua portuguesa. 2.ed.

São Paulo: Scipione, 2004.

NICOLA, José de; INFANTE, Ulisses. Gramática contemporânea da língua portuguesa. 15.ed. São Paulo: Scipione, 2004.

SACCONI, Luiz A. Gramática essencial ilustrada. São Paulo: Moderna, 1998. 
ANEXOS 


\section{ANEXO 01}

\section{Questão 3 - Prova final - Nível Intermediário II/ EEC}

A continuación verás algunas imágenes desordenadas de lo que le pasó a Francisco Recuerda. Ordénalas e intenta contar en pasado esta fantástica aventura explicando los detalles de los dibujos. Utiliza las expresiones aprendidas este semestre - si/ aunque/ mientras (mientras tanto)/ así que/ conque/ con lo cual (...) - para organizar tu relato. (Puedes ordenar los dibujos de acuerdo con tu interpretación, desde que esta organización forme una secuencia coherente).

(Ejercicio adaptado de Abanico. Cuaderno de ejercicios, p. 36. Barcelona: Difusión, 1995.)

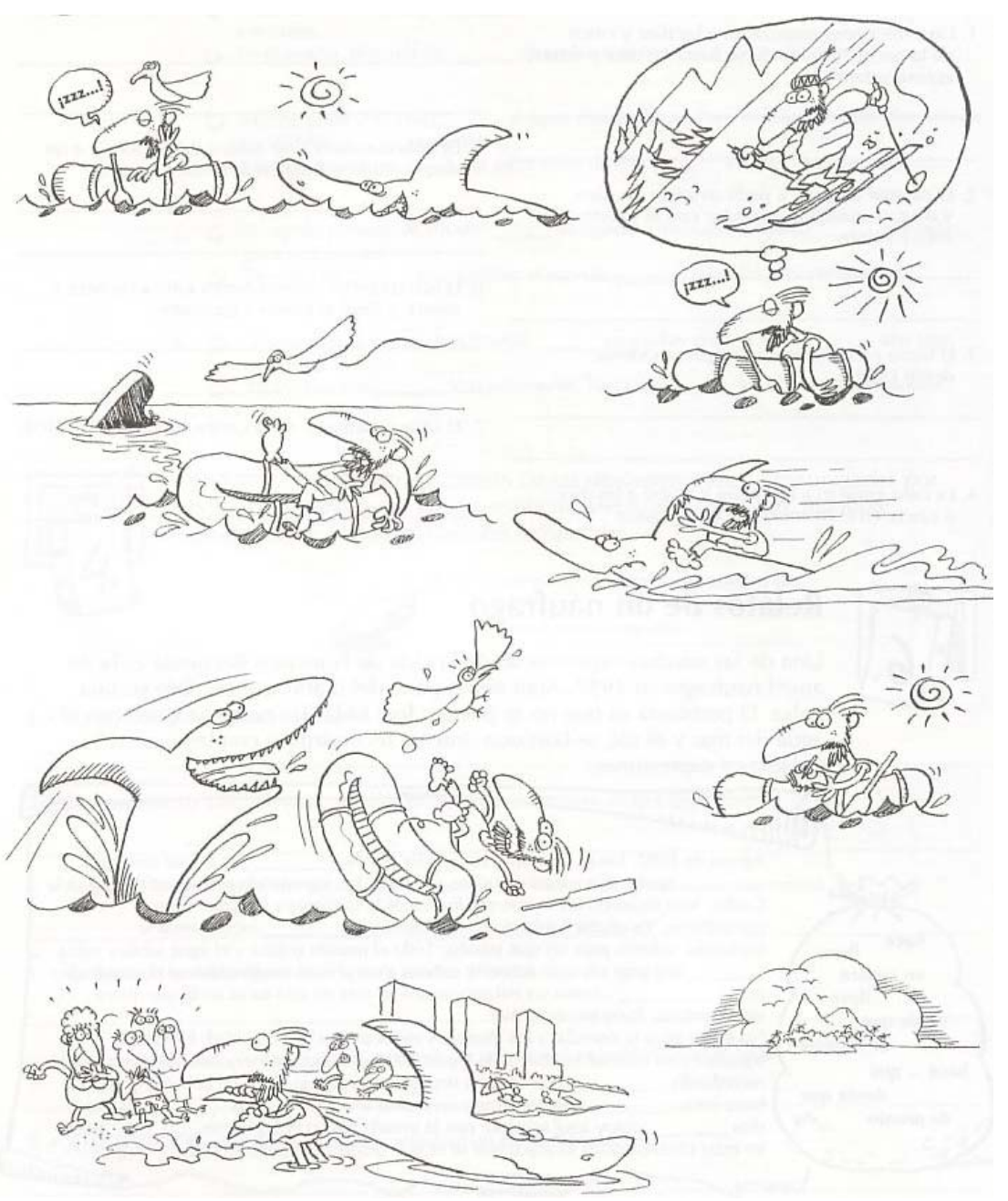




\section{ANEXO 02}

\section{Questão 1 - Prova final - Nível Avançado I/ EEC}

¿Qué harías si, después de haber pagado un dineral por un viaje organizado, resulta que poco o nada de lo prometido era verdad? ¿Por qué no escribes una carta protestando enérgicamente? Contrasta la información de este folleto turístico con la realidad que representan los dibujos.

(Ejercicio adaptado de Abanico. Cuaderno de ejercicios, p. 45. Barcelona: Difusión, 1995.)

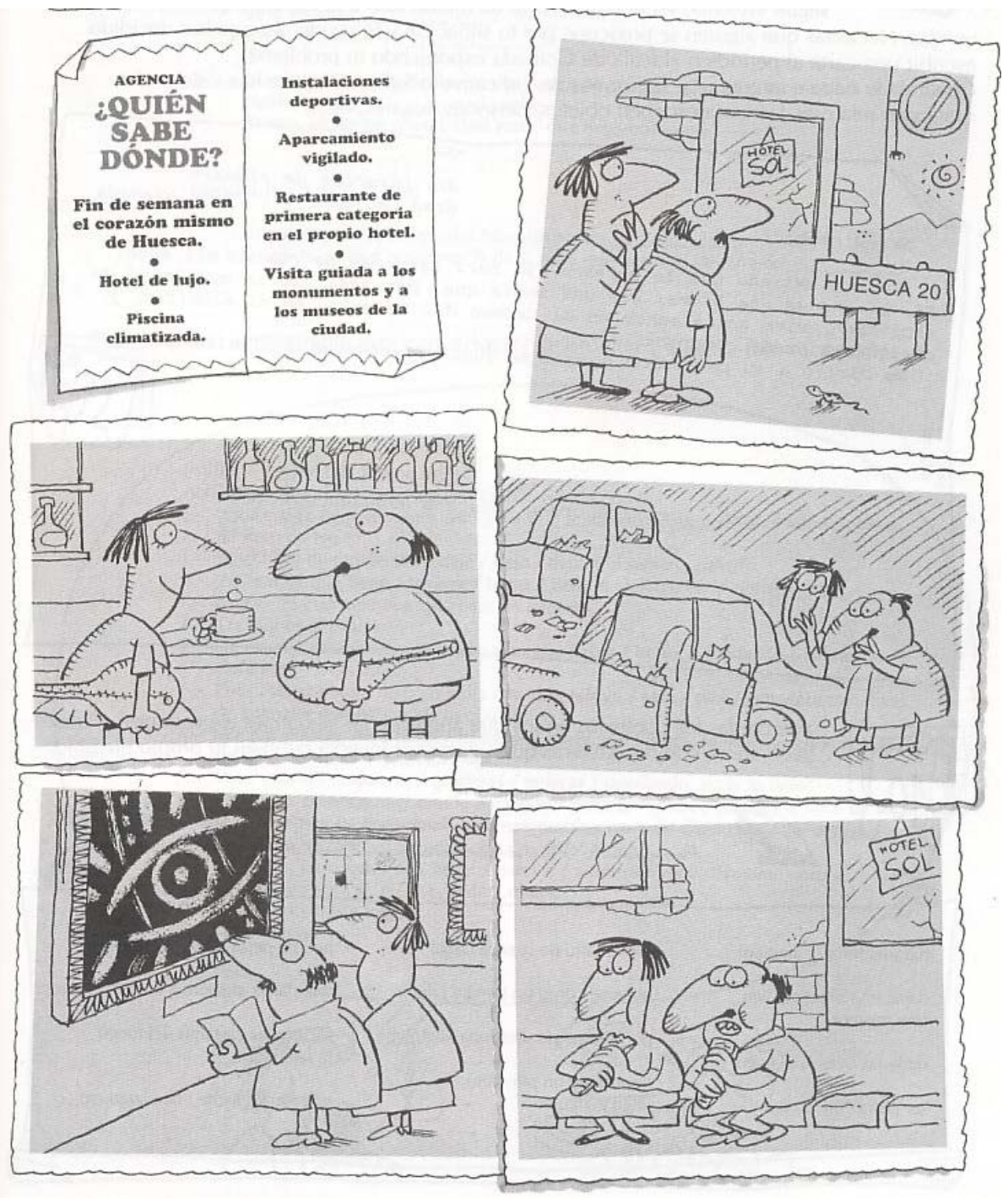




\section{ANEXO 03}

\section{Questão 4 - Prova final - Nível Avançado II/ EEC}

Estas imágenes representan diferentes trabajos y estilos de vida. Deberás compararlas. Puedes elegir un personaje de cada figura; puedes comparar en general; o puedes hablar del día a día de ellos, inventando nombres para los personajes. Como mínimo, escribe unas veinte líneas.
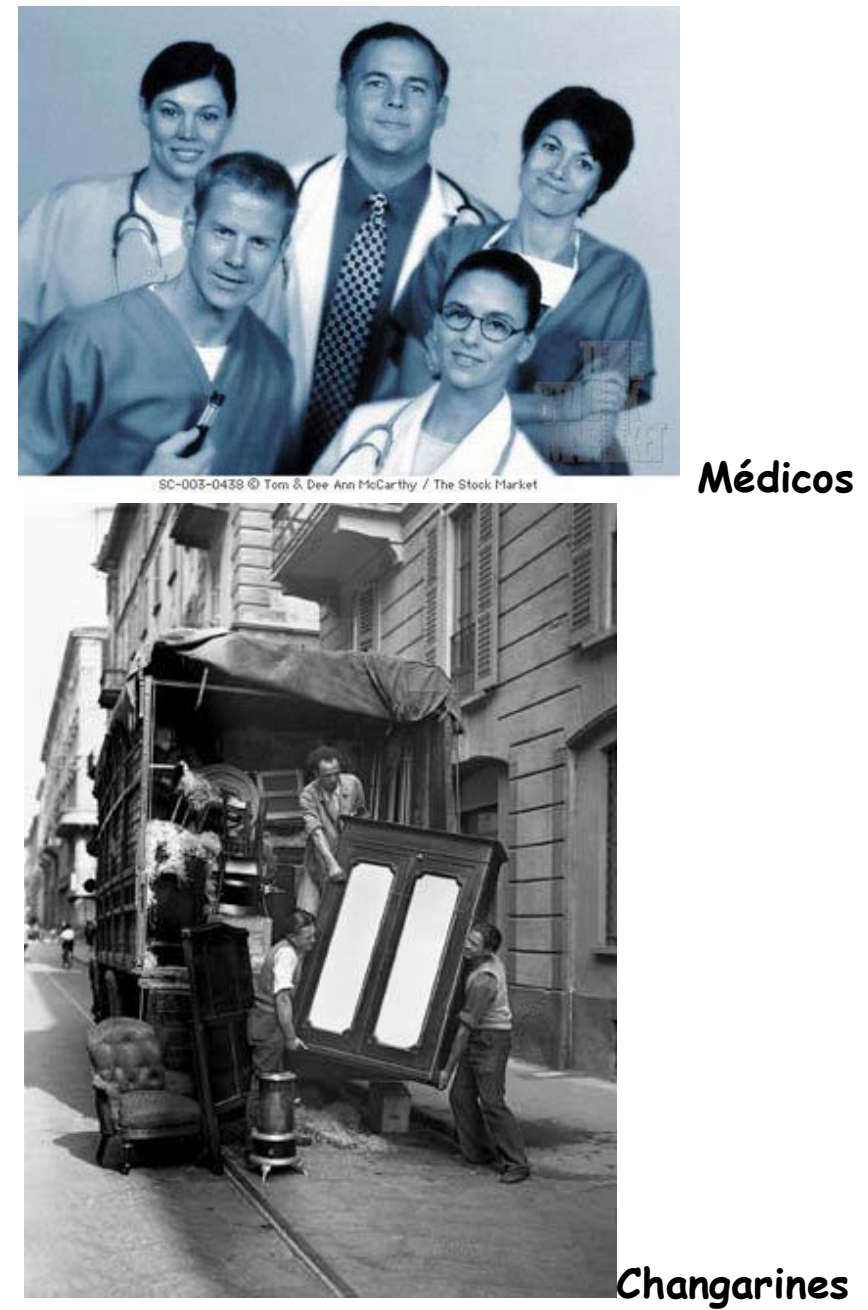


\section{ANEXO 04}

\section{Questão 4 - Prova parcial - Nível Intermediário II/ EEC}

\section{DDd Lectura}

Lee el siguiente texto y contesta las preguntas relativas a él.

\section{El juego en la cultura griega}

El juego ha sido a través de la historia una de las herramientas instintivas más poderosas de aprendizaje y se presenta en infinidad de especies de mamíferos que de manera espontánea ensayan diferentes formas de supervivencia, ubicación y aceptación dentro de un grupo, que les permite en el futuro ser el líder dentro de un clan, manada o tribu. Es, por tanto, natural que el animal humano haya dispuesto beber de esta eterna fuente creativa para el desarrollo de estados culturales más elevados. El juego humano, como cualquier fenómeno de la cultura, no se trasmite genéticamente, sino por la educación.

En la cultura griega, la constante búsqueda de la perfección del hombre en un sentido integral y amplio de la expresión, los llevó a generar sofisticados sistemas educativos en los que esa constante búsqueda los condujo por la ruta de la exaltación como método para generar ejemplos a seguir, de manera que el juego fuera el vehículo para encontrar a los mejores en todo sentido, pues el héroe o vencedor debía además complementar las mejores cualidades humanas, siendo distinguido simbólicamente con una corona de laureles. A él los poetas y los diferentes artistas cantaban sus odas y dedicaban sus obras.

Los juegos olímpicos fueron una de las expresiones más características de los sistemas educativos de la Antigua Grecia y surgieron en la segunda mitad del milenio antes de la Era Cristiana. En realidad, se llevaban a cabo como parte de festividades rituales que posteriormente recibieron el nombre de Juegos. Con el paso del tiempo decidieron efectuarlos cada cuatro años, en el santuario de Olimpia, ubicado en Peloponesio, con sus rituales y adoraciones a los dioses que vivían en el Olimpo en honor de las divinidades olímpicas. De ahí su nombre “ juegos olímpicos”.

Así, los objetivos últimos de la educación en la Antigua Grecia consistían en formar a los individuos de acuerdo con esa idea, o tipo ideal de hombre. A ello aspiraron los educadores, los poetas, los artistas y los filósofos. Las estatuas de los vencedores olímpicos representan la encarnación corporal de la dignidad y la nobleza del alma y del cuerpo humanos.

(Adaptado de www.colombia.com el 01/09/2003)

\section{Contesta:}

a) ¿Qué diferencia el juego humano del animal?

b) ¿Qué función cumplía el juego en la cultura griega?

c) ¿Según el texto, cuál era la relación entre el juego y la educación griega? 


\section{ANEXO 05}

\section{Questão 4 - Prova final - Nível Intermediário II/ EEC}

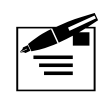

Es tu primer día de trabajo en una funeraria. Esta mañana tu jefe no ha estado allí y tú no has hecho todo. Echas a correr hacia la salida al oír a tu jefe, quien lógicamente se queda sorprendido. Pero cuando se repone de la sorpresa, no hay más remedio que explicárselo todo... Imagina que él quiere despedirte, por lo tanto tienes que darle razones para que no lo haga. Desarrolla la escena por medio de un diálogo entre tu jefe y tú. 


\section{ANEXO 06}

\section{Trabalho escrito - Nível Avançado II/ EEC}

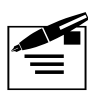

3.1 ¿Has visto a la película "Tesis" , de Alejandro Amenábar? Lee la sinopsis a continuación:

\footnotetext{
Tesis (España, 1995)

126 minutos. Suspense. Versión Original Subtitulada.

Ángela prepara su tesis sobre la violencia audiovisual. Mientras investiga, descubre unas películas snuff , cintas en las que se graban crímenes reales. Una chica de su facultad aparece en esas cintas y todo apunta a que uno de sus compañeros, Bosco, por el que Ángela siente una extraña atracción, podría ser el responsable de los asesinatos. Durante el desarrollo de la investigación, Ángela pone su vida en peligro: ella puede ser la próxima protagonista de una película snuff.

Dirección: Alejandro Amenábar

Reparto: Ana Torrent, Fele Martinez, Eduardo Noriega.
}

Ahora imagina que eres un periodista y te toca escribir una sinopsis para la película "Taxi", de Carlos Saura, que acaba de estrenar en tu ciudad. Hazlo siguiendo el modelo que te hemos dado.

3.2 Además de escribir una sinopsis, te piden que hagas la crítica de "Taxi". Para ayudarte, te ofrecemos el siguiente esquema:

a) Presentación de la película: género, tipo de película (drama, policíaca, suspense, fantástica, ciencia ficción, terror, comedia, etc.).

b) Descripción: resumen del argumento, personajes e interpretación, elementos técnicos (dirección, guión, ambientación, decorados, escenografía, música...) $\rightarrow$ HACER VALORACIONES PERSONALES.

c) Conclusión: valoración final, señalando si la película tendrá éxito o no junto al público. Recomienda (o no) la película al público, justificando tu opinión.

(Adaptado de CHAMORRO GUERRERO et alii. Abanico. 6.ed. Barcelona, Difusión, 2001) 
ANEXO 07

FICHA DE ACOMPANHAMENTO

\section{NOME:}

CURSO:

DATA:

1. Selecione sua faixa de idade:

( ) de 10 a 20 anos

( ) de 20 a 30 anos

( ) de 30 a 40 anos

$$
\begin{aligned}
& \text { ( ) de } 40 \text { a } 50 \text { anos } \\
& \text { ( ) de } 50 \text { a } 60 \text { anos } \\
& \text { acima de } 60 \text { anos }
\end{aligned}
$$

2. Selecione seu sexo:

( ) Feminino

( ) Masculino

3. Selecione seu grau de instrução:

( ) nível fundamental completo/incompleto

( ) nível médio completo/ incompleto

( ) nível universitário completo/ incompleto

( ) mestrando(a)

( ) doutorando(a)

( ) outros:

4. Profissão: Descrição das atividades que realiza em seu trabalho

5. Atualmente, qual é o seu contato com a língua espanhola?
( ) somente aula
( ) trabalho
( ) leitura
( ) música
( ) amigos
( ) TV a cabo
( ) parentes
( )

6. Qual é a imagem que você tem da língua espanhola?

7. Estudou espanhol anteriormente?

( ) Sim ( ) Não 
8. a) Estudou alguma outra língua anteriormente?

( ) Sim ( ) Não

b) Se sim, qual(is)?

$\begin{array}{lll}\text { ( ) Inglês } & (\text { ) Japonês } & (\text { ) Francês } \\ \text { ( ) Latim } & (\text { ) Italiano } & (\text { ) Grego }\end{array}$

c) Quanto tempo faz que estudou tal(is) língua(s)?

( ) menos de 10 anos ( ) entre 30 e 40 anos atrás

( ) entre 10 e 20 anos atrás ( ) mais de 40 anos atrás

( ) entre 20 e 30 anos atrás

d) Em que tipo de instituição estudou língua(s) anteriormente?

( ) Escola regular

( ) Instituto de idiomas

( ) Aulas particulares

( ) Outra(s):

e) Acredita que seu desempenho tenha sido:

( ) Insuficiente

( ) Regular

( ) Bom

( ) Excelente

9. Em sua concepção, qual(is) atividade(s) deve(m) estar presente(s) em um curso de língua? Escolha 4 (quatro) dentre as apresentadas a seguir:

( ) Leitura de textos (jornais, revistas, textos literários, etc.)

( ) Tradução de textos

( ) Exercícios de gramática

( ) Produção de texto escrito

( ) Jogos

( ) Música

( ) Dramatização

( ) Audição de cassetes

( ) Atividades com vídeo

( ) Outra(s):

10. Selecione 4 (quatro) áreas [no máximo] pelas quais tem interesse:

( ) Artes e Cultura

( ) Ciência

( ) Governo e Política

( ) Ciências Humanas

( ) Educação e Formação

( ) Informática e Internet

( ) Entretenimento

( ) Esporte e Lazer

( ) Notícias e Mídia

( ) Saúde

( ) Sociedade

( ) Outra(s): 


\section{ANEXO 08}

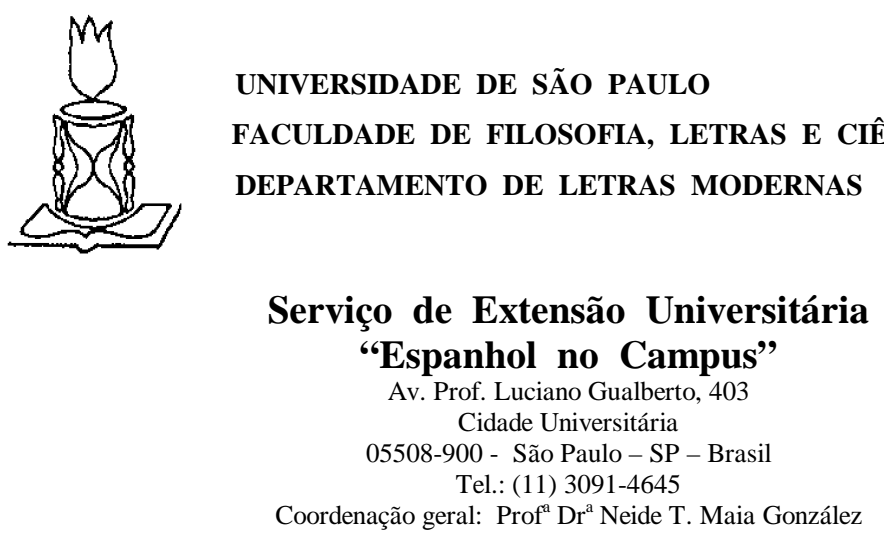

A U T T O R I Z A Ç $\tilde{A} \mathbf{O}$

$\mathrm{Eu}$, , aluno/a do

Espanhol no Campus, autorizo a utilização dos textos por mim elaborados para constituirem o corpus que servirá de material de pesquisa para os professores e alunos de pós-graduação da Área de Espanhol: Língua, Literatura e Tradução. Estou ciente de que meus dados pessoais serão mantidos em sigilo.

São Paulo, de de 


\section{ANEXO 09}

\section{$1^{a}$ Producão escrita: casa - Nível Básico I/ EEC}

\section{Hacia la redacción}

1. Estas personas buscan nuevas amistades y escriben en El Diario. Escucha sus cartas en la grabación y acompaña la lectura en el periódico.

\section{El Diario}

\section{Correspondencias}

Mi nombre es Charo. Soy española, $1,70 \mathrm{~m}$, ojos azules y pelo castaño. Soy delgada y muy hermosa. Tengo 25 años, soy aficionada a asuntos esotéricos, a la meditación y a la vida naturalista. Estudio Astronomía y Numerología. Me gustan los chicos inteligentes, comunicativos y simpáticos. Me gustaría conocer especialmente a los chicos brasileños. Mi dirección es Avda. de las Américas, número 2.381, Madrid, España.

Chica joven, 18 años, uruguaya, estudiante de alemán, ojos verdes, pelirroja, de pelo rizado y largo, 1,80m y delgada desea contactar con chicos de todo el mundo para sincera amistad. Mi dirección es C/ Flores de Arauco, 1.520, Código Postal 12.353, Punta del Este, Uruguay (Pamela María Guzmán).
Muchacho lindo, simpático, rico, soltero e inteligente, 26 años, ojos azules, pelo largo, rubio y lacio, piel morena, con bigote, cuerpo atlético, muy sensual y cariñoso, desea algo más que amistad con chicas brasileñas. Hablo un poco de Portugués y escribo bien en Inglés. ¡Chicas, a escribirme! Les aguarda Lucho. Dirección: Avda. Maipú, 27, Buenos Aires, Código Postal 89.504, Argentina.

Viudo solitario desea corresponderse con mujeres interesantes para larga amistad. Soy jubilado, tengo 60 años, pelo grisáceo, un poco calvo, $1,75 \mathrm{~m}$ de altura, soy gordo, tengo ojos castaños y piel clara. Me gusta el deporte. Y ya fui torero. Soy muy romántico. Mandar respuesta con foto a Don José Francisco Tomás Hernández

Manchego. Calle de Alcalá $n^{\circ} 576$, Madrid, Código Postal 46.961, España.

(Extraído de: BRUNO \& MENDOZA, Hacia el español: Nivel Básico. São Paulo, Saraiva, 5.ed., 2000, p.107.)

2. Elige una de las cartas y escríbele al remitente una respuesta que corresponda a sus expectativas. 


\section{ANEXO 10}

\section{$2^{\mathrm{a}}$ Produção escrita: casa - Nível Básico l/ EEC}

\section{Hacia la redacción}

2. Observa este dibujo y lee el texto. A continuación, rellena los espacios en blanco con la información que falta.

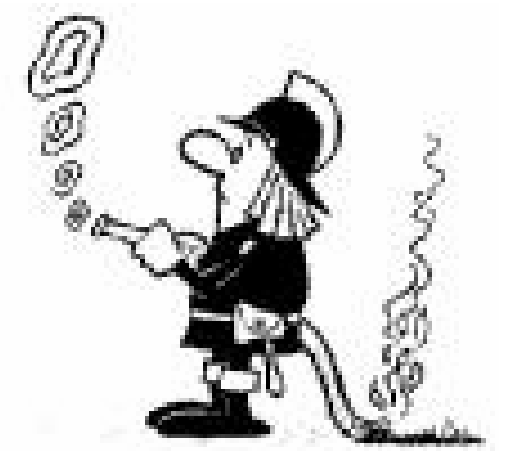

www.feuerwehr.pforzheim.de/gast
Se llama

Todos los días se levanta a las y desayuna en casa. Luego va a trabajar. Es .....

mañanas trabaja en las tardes a casa a las ........... cena con $\mathrm{y}$ vive en

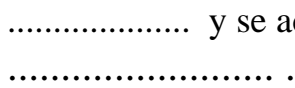

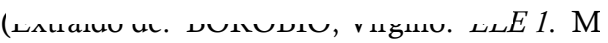

3. Ahora imagina que eres guionista de cine y que acaban de encargarte el guión de una película:

a) ¿Qué género tiene la película? Elige uno ${ }^{(*)}$.

b) Los productores te piden que escribas un resumen con informaciones sobre el/la protagonista de la película, a saber:

— cómo es físicamente;

— cuáles son sus rasgos psicológicos;

— a qué se dedica;

— cuáles son sus gustos y aficiones;

— qué cosas hace en un día normal (rutina). 


\section{ANEXO 11 \\ $\underline{3^{\mathrm{a}} \text { Produção escrita: prova parcial - Nível Básico l/ EEC }}$}

\section{VERSÃO 1:}

Vamos a imaginar que vives en un edificio cerca de la Avenida Paulista. El último jueves, como no tenías nada para hacer, decides quedarte en la ventana viendo el va y viene de las personas. Sin embargo, de repente, ves a un hombre y a una mujer secuestrando a un gran empresario. Inicialmente, tienes mucho miedo, pero, enseguida, decides llamar a la policía para contarles todo lo que viste. Haz el "retrato robot" de los dos secuestradores. Para ello utiliza las características físicas que has estudiado en el curso ${ }^{103}$.

\section{VERSÃO 2:}

Te ha tocado un viaje a España y has conocido allá a un(a) amigo(a) muy especial. Como quieres que tu familia lo (la) conozca, envíale una foto. Preséntalo(la) a tu familia incluyendo las siguientes informaciones:

a) Explica quién es, su nombre, edad, dirección, profesión y nacionalidad;

Cómo es físicamente y de carácter.

\footnotetext{
${ }^{103}$ Ejercicio basado en Abanico, p. 15.
} 


\section{ANEXO 12 \\ $\underline{4^{a} \text { Produção escrita: prova final - Nível Básico I/ EEC }}$}

\section{VERSÃO 1:}

Lee el siguiente texto:

Dormitorio de Señorita, $1937^{104}$

Entrando a la derecha una cama de plaza y media, con la cabecera pegada a la pared y encima un crucifijo con la cruz de madera y el Cristo de bronce. A la izquierda de la cama una estantería cargada de libros de texto de la escuela normal y algunas novelas. A la derecha de la cama una mesa de luz con una lámpara. En la pared opuesta a la cama una ventana con, a un lado, un estante adornado de muñecas y, al otro lado, una cómoda con espejo. La pared opuesta a la puerta de acceso enteramente ocupada por un ropero. En el ropero a un lado se alinean cajones cargados de ropa interior, blusas, pañuelos, medias, toallas y sábanas. Escondidos entre sábanas de hilos bordadas, dos libros científicos titulados "Educación para el matrimonio" y "La verdad sobre el amor".

¿Puedes imaginar cómo es esta "señorita"? Escribe un texto contándonos cómo se llama (nombre, apellido, apodo), qué hace (profesión, dónde trabaja), su vida cotidiana (su rutina y sus fines de semana) y cómo es físicamente; si es posible intenta emplear pero y sin embargo en tu texto:

\section{VERSÃO 2:}

Consigues cambiar tu vida profesional. iQué bien! Trabajas en la revista "Los Famosos" y haces tu primera entrevista con una gran actriz. Ahora tienes que escribir algunas cosas que descubriste sobre la vida de ella para la revista. El artículo deberá contener las siguientes informaciones:

a) Cómo se llama y dónde vive

b) Cómo es su vivienda, cuántas habitaciones tiene;

c) Cómo es su rutina;

d) Qué hace los fines de semana; qué (no) le gusta, molesta.

\footnotetext{
${ }^{104}$ Texto adaptado de Boquitas Pintadas, de Manuel Puig, por los profesores Fernanda S.C. Rodrigues y Marcio Funcia.
} 


\section{ANEXO 13 \\ $11^{\text {a Produção escrita: casa - Nível Básico II/ EEC }}$}

\section{BIOGRAF́A}

Si te gusta saber sobre la vida de los famosos, de celebridades del mundo de las ciencias, de tus escritores favoritos, seguro que ya has leído alguna biografía. Los textos biográficos cuentan la historia de la vida de alguien:

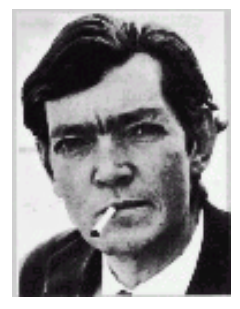

\section{JULIO CORTÁZAR}

Aunque de padres argentinos -con ascendencia vasca, francesa y alemana- Julio Cortázar nació accidentalmente en Bruselas. Fue en 1914, mientras los obuses estallaban en la ciudad. Su padre, técnico en materias económicas, estaba al frente de una delegación comercial que trabajaba en la embajada argentina en Bélgica. Al ser Argentina un país neutral, a la familia Cortázar se le permitió, durante la guerra, refugiarse en otros países europeos también neutrales: Suiza (Zurich) y luego España (Barcelona).

En 1951 se alejó de Argentina y desde entonces trabajó como traductor independiente de la Unesco, en París. En 1938 publicó, con el seudónimo Julio Denis, el librito de sonetos Presencia. En 1949 apareció su obra dramática Los reyes. Apenas dos anos después, en 1951, publicó Bestiario: ya surgía el Cortázar deslumbrante por su fantasía y su revelación de mundos nuevos que iban enriqueciéndose en su obra futura: los inolvidables tomos de relatos, los libros que desbordan toda categoría genérica (poemas-cuentos-ensayos a la vez), las grandes novelas: Lospremios (1960), Rayuela (1963), 62/Modelo para armar (1968), Libro de Manuel (1973). Julio Cortázar murió en 1984.

(Extraído y adaptado de www.sololiteratura.com y www.flakozitas.com.br)

Ahora ponte en la piel de un biógrafo y escribe un texto sobre la vida de tus padres o abuelos, con datos como: dónde nacieron, qué cosas hacían cuando eran chicos, cómo eran fisicamente, dónde vivieron, qué cosas hicieron de adultos (profesiones, viajes, etc.) y cómo se conocieron. 


\section{ANEXO 14 \\ $\underline{2^{a} \text { Produção escrita: casa - Nível Básico II/ EEC }}$}

\section{DIARIO DE VIAJE}

\section{BAUTIZADO CON EL NOMBRE DE SEDNA}

Descubren el que podría ser el décimo planeta del Sistema Solar : el planeta Sedna sería más pequeño que la Luna.

\section{EUROPA PRESS}

LONDRES.- El telescopio espacial Spitzer ha localizado el que podría ser un nuevo planeta del Sistema Solar, que giraría a una distancia mucho mayor que el resto y al que han bautizado con el nombre de Sedna, en honor a la diosa inuit (o esquimal) del océano, según informa la BBC.

El planeta también ha sido detectado por el telescopio espacial Hubble y la agencia espacial estadounidense (NASA) anunciará más detalles de sus observaciones. El planeta fue descubierto en el curso de un proyecto de investigación dirigido por Michael Brown, del Instituto de Tecnología de California.

(Extraído y adaptado de www.elmundo.com de 16 de marzo de 2004)

Pasando un poco a la ficción... Vamos a imaginar que se desc ubrió que este es un planeta habitado por formas de vida totalmente desconoc idas por los seres humanos. Necesitan urgentemente a una persona capacitada para explorar Sedna . Tú, que eres el mejor de los expertos en este tema, has sido seleccionado para esta gran misión.

Durante una semana tendrás que apuntar en tu diario de viaje todas las cosas que veas día a día. No te olvides de que todos los estudios sobre la civilización de Sedna dependen de tus apuntes. Sé lo más objetivo en todos los detalles de tus descripciones de tareas y obsenvaciones. Sigue el modelo abajo y ¡BUEN VIAJ E!

$\mathrm{O}$

Domingo (10-V-2050):

Hemos llegado a Sedna alrededor del mediodía (hora de la Terra). La nave espacial no ha tenido averías...

$\mathrm{O}$

$$
\text { Lunes (11-V-2050) }
$$

Nos hemos despertado a las ocho a causa de un ruido muy fuerte. He salido del abrigo a ver qué pasaba y... 


\section{ANEXO 15}

$\underline{3^{a} \text { Produção escrita: prova parcial - Nível Básico II/ EEC }}$

Comenta brevemente como se organiza

actualmente la rutina de las parejas en

nuestro país. 


\section{ANEXO 16}

\section{$\underline{4^{a} \text { Produção escrita: prova final - Nível Básico II/ EEC }}$}

Viajar es siempre una experiencia inolvidable y nos ofrece experiencia para planear otros viajes. Haz un relato contando sobre un viaje que hayas hecho y los planes que tienes para una próxima aventura. No dejes de incluir, entre otras, las siguientes informaciones:

- adónde fuiste y con quién;

- qué lugares visitaste y qué te pareció;

- qué te pasó de interesante;

- qué planes tienes para un próximo viaje y por qué;

- qué harás. 


\section{ANEXO 17}

$\underline{1^{a} \text { Produção escrita: casa - Nível Intermediário I/ EEC }}$

\section{¿Y el futuro?}

Eres el/ la mejoradivino/a de la ciudad, $y$ te has hec ho

famoso/a por tus predicciones que nunca fallan. Eige a uno de los clientes (1, 2, 3, 4 ó 5) y cuéntale qué cosas le van a pasaren el futuro (amores, familia, camera, viajes, éxitos, fracasos, etc.):

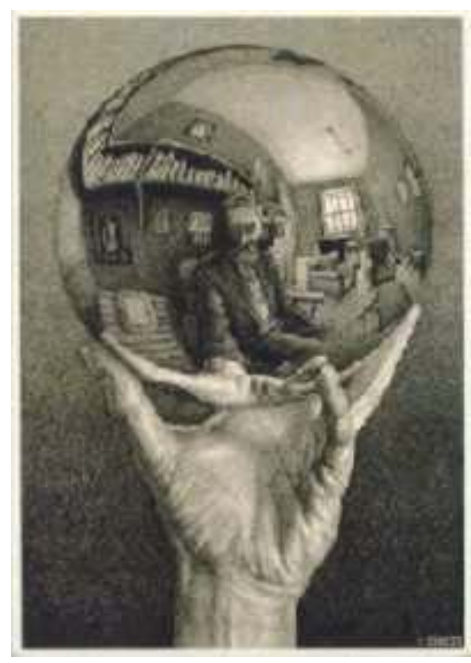

1. Un cura/ una monja con dudas sobre su vocación religiosa;

2. Un surfista que está empezando su carrera;

3. Un político implicado en un gran escándalo financiero;

4. Una modelo famosa que quiere cambiar de profesión;

5. Un chico joven que sueña con llegara ser un cientista tan famoso como Enstein; 


\section{ANEXO 18 \\ $\underline{2^{\mathrm{a}} \text { Produção escrita: casa - Nível Intermediário I/ EEC }}$}

\section{Fijate en el siguiente anunc io publicitario:}

\section{$\mathrm{Na}$ Espanha existe um caminho}

que se faz com o corpo e com a

alma. Desde o século $X$ até os

dias de hoje, peregrinos do mundo

inteiro vêm percorrer o Caminho

de Santiago, uma rota única pela

natureza e espiritualidade. Una-

se a eles. Descubra 116 cidades

e vilas com mais de 1.800

construções de valor histórico e

artístico, e desfrute da

hospitalidade de um povo que

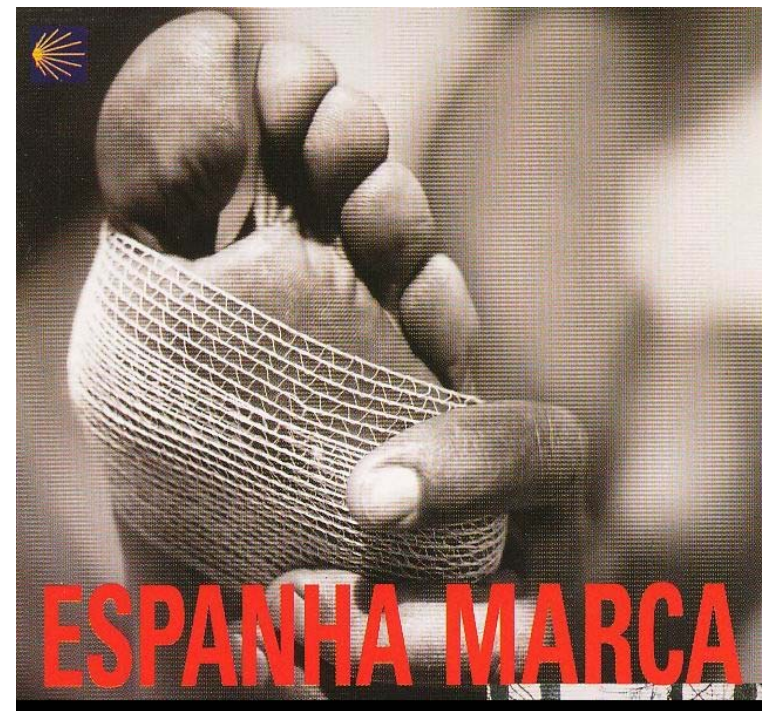

você jamais esquecerá. Venha e

faça parte do milagre.

Seja marcado pela

www.spain.info

Con el fin de atraer a más visitantes, la secretańa de turismo de tu ciudad ha decidido hacer anuncios como el que acabas de leer. Es más, los anuncios se refieren a los muchos barios de la ciudad y hablan de lo más interesante en cada zona.

Imagina que eres publicitario y formas parte del equipo responsable de esa campaña. Por casualidad, a ti te toca elaborar el anunc io comespondiente al bamio donde vives y que conoces como nadie. A vercómo lo haces... 


\section{ANEXO 19}

3ㅁ Produção escrita: prova parcial - Nível Intermediário l/ EEC

\section{Escritura}

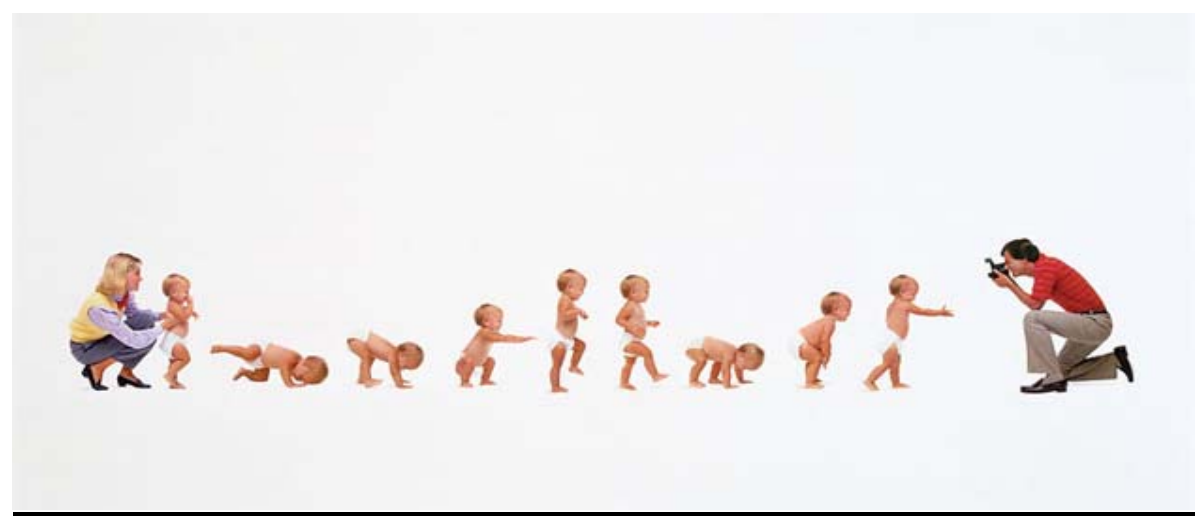

4) Describe lo que ves en la imagen. Puedes relatar en presente, usando los gerundios. 0 si prefieres, cuenta todo lo que hizo el bebé, usando el pretérito. ( 2.5 puntos) 


\section{ANEXO 20}

$\underline{4^{a} \text { Produção escrita: prova final - Nível Intermediário I/ EEC }}$

Primero describe cada imagen. Luego, compáralas. Encuentra las semejanzas y las diferencias.
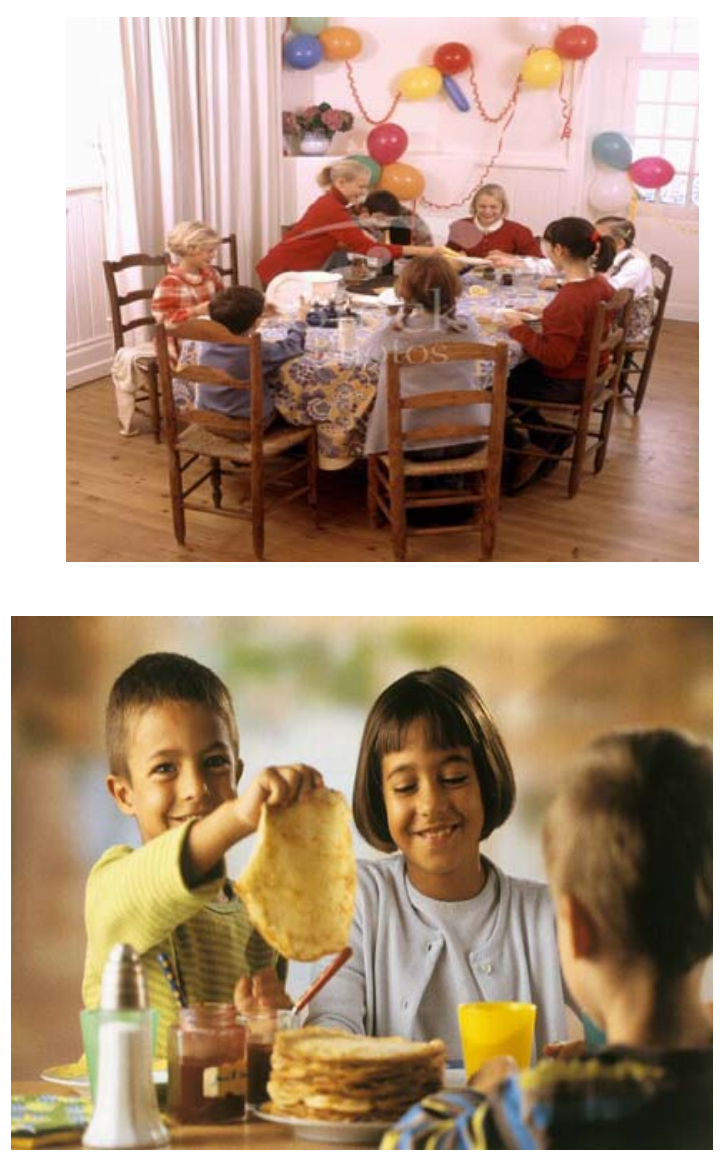


\title{
ANEXO 21
}

1ª Produção escrita: casa - Nível Intermediário II/ EEC

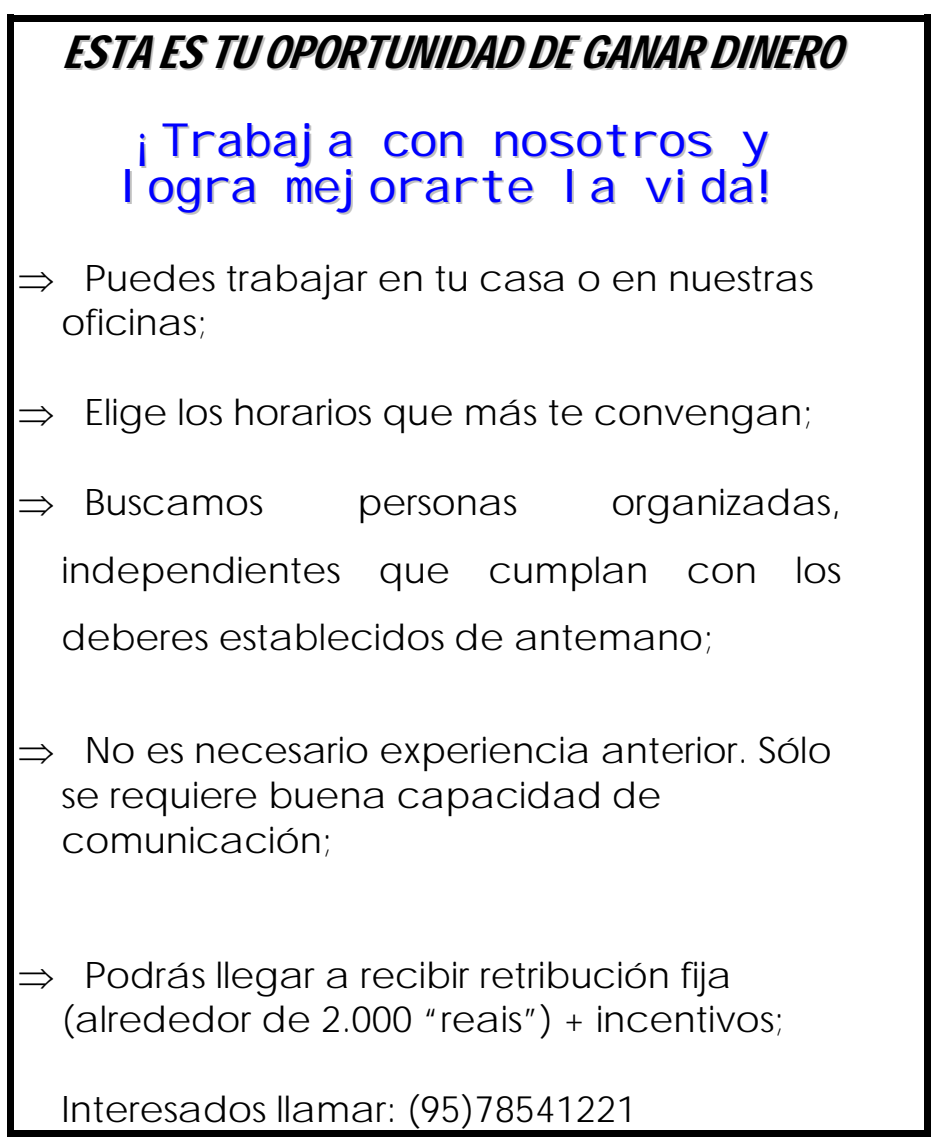

\begin{abstract}
Al leer este anuncio en el periódico " $\boxminus$ Planeta", te pusiste muy curioso/a para saber de qué se trataba realmente. la verdad es que estás interesado/a en el empleo pero antes quieres sacar algunas dudas. Así que decides llamaral teléfono que está en el anuncio y hacerles todas las preguntas sobre ese trabajo.
\end{abstract}

Escribe en forma de diálogo la conversación telefónica que tuviste con la empresa. 


\section{ANEXO 22}

\section{2ª Produção escrita: casa - Nível Intermediário II/ EEC}

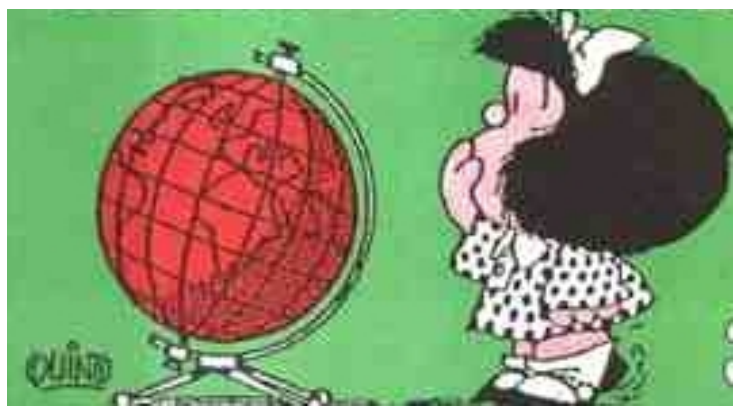

www.quino.com.ar

Harás un interc ambio con un/a estudiante de

É/Ela pasará un mes en tu casa y, lo más importante, viviendo como vives.

Escríbele un guión para que se entere de todo lo que debe hacer (consejos, recomendaciones) y de todo lo que tiene que hacer (obligaciones) durante esa temporada. 


\title{
ANEXO 23 \\ 3
}

A mucha gente le gusta leer la sinopsis de una película antes de verla. Algunas sinopsis tienen un propósito meramente comercial, otras son descriptivas y hay todavía aquellas con comentarios críticos.

¿Te acuerdas de esta película? A ver si estás de acuerdo con esta sinopsis. ¿Cómo la clasificarías?

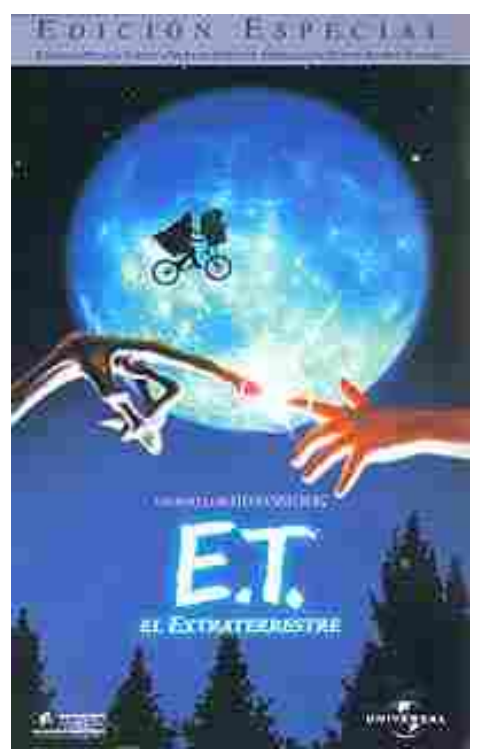

\author{
Dirección: Steven Spielberg \\ Género: Aventuras \\ Clasificación: Apta para todo público \\ "Un pequeño extraterrestre perdido a tres \\ millones de años luz de su hogar. Un niño \\ solitario de diez años que se siente sólo y quiere \\ llevárselo a casa. Dos vidas transformadas por \\ una aventura atemporal y una amistad que no \\ tiene límites. Steven Spielberg te invita a \\ recordar una de las películas más emocionantes \\ de la historia. Vuelve a descubrir E.T EI \\ Extratarrestre en esta edición especial de su 20 \\ aniversario con escenas inéditas, efectos \\ especiales mejorados y una banda sonora \\ remasterizada digitalmente. Ganadora de cuatro \\ Oscar y dos Globos de Oro, entre ellos el de \\ Mejor Película, ET es una historia divertida, \\ emocionantes y inolvidable."
}

http://www.blockbuster.es/ficha_pelicula.php?idp=30837

Imagina que eres periodista de "Ocio en el Campus" y a ti te toca escribir la sinopsis de la película que has visto en el curso. Hazlo utilizando los datos que juzgues necesarios y, por supuesto, ¡sin contarnos el final! 


\section{ANEXO 24}

$\underline{4^{a} \text { Produção escrita: prova parcial - Nível Intermediário II/ EEC }}$

Acabas de llegar a Dinamarca y todo para ti es desconocido. Sus habitantes tienen hábitos y costumbres diferentes de los nuestros pero están interesados en conocernos y tratarnos mejor. Por lo tanto, te piden que escribas un "Manual de instrucciones generales para tratar bien a los turistas brasileños". Para hacerlo, usa expresiones impersonales del tipo hay que, es necesario, hace falta etc. 


\section{ANEXO 25}

$\underline{5^{\text {a }} \text { Produção escrita: prova final - Nível Intermediário II/ EEC }}$

Es tu primer día de trabajo en un zoológico. Esta mañana tu jefe no ha estado allí y tú no has hecho todo. Echas a correr hacia la salida al oír a tu jefe, quien lógicamente se queda sorprendido. Pero cuando se repone de la sorpresa... No te queda más remedio que... explicárselo a tu jefe... Imagina que él quiere despedirte. Dale razones para que te eche a la calle o para que te mantenga en el puesto. Utiliza las expresiones aprendidas este semestre - aunque/ mientras (mientras tanto)/ así que / conque/ con lo cual (...) para organizar tu relato. 


\section{ANEXO 26}

$\underline{1^{\text {a }} \text { Produção escrita: casa - Nível Avançado I/ EEC }}$

Actividad 1:

Redacte una carta a partir de uno de los temas que se le proponen utilizando el tono y estilo adecuados:

a) $\mathrm{Al}$ abrir un bote de mermelada se ha encontrado usted una mosca dentro. Indignadísimo/a, decide escribir a la Asociación de Consumidores explicando el caso, dando todo tipo de informaciones sobre el producto en cuestión, y pidiendo que se tomen medidas legales contra el fabricante.

b) En televisión existe un programa que ayuda a buscar a personas desaparecidas. Su esposo/a desapareció sin dejar rastro hace seis años un día que salió a comprar tabaco. Cree que este programa puede ser su última esperanza de encontrarlo/a. Escríbales y no olvide incluir datos como descripción física, carácter, edad, ropa que llevaba... Puede apuntar también posibles causas de su desaparición, lugar donde podría estar... 


\section{ANEXO 27}

$\underline{2^{\mathrm{a}} \text { Produção escrita: casa - Nível Avançado l/ EEC }}$

\section{Actividad 2:}

Hace unos años tuvo una relación hermosa y apasionada (de ésas que dejan un buen recuerdo en la memoria) que la excesiva juventud rompió. El azar ha hecho que coincidan en un aeropuerto y que hablen de lo que vivieron juntos, de cómo han rehecho sus vidas y de cómo se encuentran ahora. Convierta esa conversación en un texto escrito, en forma de diálogo.

Adaptado de: Gálvez et alii. Preparación Diploma Superior Español Lengua Extranjera. Madrid, Edelsa, 1994, p. 57. 


\title{
ANEXO 28
}

3. Produção escrita: casa - Nível Avançado // EEC

\begin{abstract}
Actividad 3:
Van a ejecutar a un condenado a muerte por un infanticidio. Ha confesado la autoría del crimen y se tienen pruebas contundentes de ello. Es usted periodista y está a favor/ en contra de la pena de muerte. Escriba un artículo para un periódico defendiendo o atacando la decisión de llevar a cabo dicho castigo. No olvide poner un titular en su artículo.

Extraído de: Gálvez et alii. Preparación Diploma Superior Español Lengua Extranjera. Madrid, Edelsa, 1994, p. 57.
\end{abstract}




\section{ANEXO 29}

$\underline{4^{a} \text { Produção escrita: prueba parcial - Nível Avançado I/ EEC }}$

Redacción

2) Haga una disertación sobre el tema ¿Por qué tener hijos y cuáles sus consecuencias? Para darle cohesión y coherencia, utilice correctamente los marcadores textuales estudiados en sala. (2.5 puntos):

¿Por qué tener hijos y cuáles sus consecuencias? 


\section{ANEXO 30 \\ $\underline{5^{a} \text { Produção escrita: prueba final - Nível Avançado I/ EEC }}$}

\section{Redacción}

2) ¿Qué querías ser cuando eras pequeño? ¿Te has convertido en la persona que querías? Y ¿cuáles son tus planes o sueños para el futuro, para la vejez? Escribe un pequeño texto contando qué pensabas ser cuando eras pequeño y comparándolo con lo que has llegado a ser y con tus deseos para el futuro. Usa para ello los pasados, los verbos de cambio, las frases iniciadas por: cuando, si, deseo (deseaba) que, espero (esperaba) que, ojalá. (2.5 puntos) 
ANEXO 31

$11^{\text {a }}$ Produção escrita: casa - Nível Avançado II/ EEC

\section{Actividad 1:}

Situación:

Es verano y estás de vacaciones en la playa desde hace una semana. Tu problema es que no tienes tus maletas. En el aeropuerto las confundieron con otras y las enviaron a Tanzania.

Objetivo:

Quieres recuperar tus maletas o recibir una indemnización. Has hablado ya con muchos encargados dentro del aeropuerto pero ninguno te ha solucionado el problema. Ahora quieres solucionarlo directamente con el Jefe del “departamento de objetos perdidos” de la compañía áerea Zap Airlines, el Sr. Gutiérrez.

Escribe un diálogo representando la conversación que tienes con el Sr. Gutiérrez.

Extraído y adaptado de: Pinilla \& Acquaroni. ¡Bien dicho! 2. ed. Madrid, SGEL, 2002, p. 67. 


\section{ANEXO 32}

\section{$\underline{2^{a} \text { Produção escrita: casa - Nível Avançado II/ EEC }}$}

\section{Actividad 2:}

Los tejados de las casas están muy cerca los unos de los otros pero... ¡qué distantes están los corazones de los hombres en las grandes ciudades!

Escribe un artículo para un periódico sobre el tema de la soledad en la sociedad moderna.

Adaptado de: Gálvez et alii. Preparación Diploma Superior Español Lengua Extranjera. Madrid, Edelsa, 1994, p. 56. 


\title{
ANEXO 33
}

\section{$3^{\text {a }}$ Produção escrita: casa - Nível Avancado II/ EEC}

\author{
Actividad 3: \\ El hotel ibicenco “35”, que se dedica exclusivamente a un turismo juvenil \\ con edades que no rebasen la cifra señalada, necesita para la temporada \\ veraniega animadores y organizadores de actividades de entretenimiento y \\ diversión. Se requieren: personalidad abierta y comunicativa, formación \\ artística (música, baile, mimo, teatro) y dominio hablado de los idiomas \\ español, inglés y alemán. Las condiciones económicas son francamente \\ ventajosas. Envíe una carta al Sr. Peña, jefe de personal, ofreciéndose para \\ el puesto. Añada sus méritos profesionales y cualidades personales, así \\ como su experiencia si la tuviera. \\ Extraído de: Gálvez et alii. Preparación Diploma Superior Español Lengua \\ Extranjera. Madrid, Edelsa, 1994, p. 54.
}




\section{ANEXO 34 \\ $\underline{4^{a} \text { Produção escrita: prueba parcial - Nível Avançado II/ EEC }}$}

\section{Redacta - (total: 2,5)}

4.

Tú, que quieres ser un profesional estupendo, viajas a Madrid, a una reunión de trabajo. Te sientes creativo y optimista con tus ideas y dinamismo. Las cuestiones económicas te plantean problemas pues no controlas las compras y los gastos de la empresa. Las buenas relaciones entre los compañeros no te ayudaron a superarlos. Tu jefe quiere explicaciones. ¿Podrás resolver este asunto difícil? Escribe el diálogo que tendrás con tu jefe durante esa reunión. Hablarán en este diálogo solamente tu jefe y tú.

Para ayudarte:

- oír risas

- callarse y sentarse lejos del jefe

- contar una mentira / un chiste

- tardar demasiado en resolver el problema

- tratar a tu jefe como se merece 


\section{ANEXO 35 \\ $\underline{5^{a} \text { Produção escrita: prueba final - Nível Avançado II/ EEC }}$}

\section{Redacta - (total: 2,3)}

Lucía vino a decirte muy enfadada que tú hablabas mal de ella por toda la facultad. Le dijiste que era mentira, pero siguió discutiendo. Como prefieres el diálogo la discusión escribe la conversación entre Lucía y tú. No te olvides de poner algunos marcadores como por ejemplo: sin embargo, ya que, sino y otros. Estás libre para utilizar o no los temas que te sugerimos:

- ponderar la evidencia de alguna verdad - buscar complicaciones donde no las hay

- no ser tenido en consideración en algún asunto - no dirigir la palabra a alguien 
CORPORA 


\section{Corpus C1}

\section{INTERMEDIÁRIO II - A (I2.A)}

Total de alunos: 10

(I2.A.1) [Francisco] Se entregó por un momento [a] aquella tranquilidad vigilada por una gaviota. Fue sorprendido por un tiburón que casi le mató.

(I2.A.2) El tiburón fuiste, entonces, de encuentro a la isla y fuera del agua cansó y fue carregado por Francisco que ha se tornado muy famoso con la historia.

\section{INTERMEDIÁRIO II - B (I2.B)}

Total de alunos: 14

(I2.B.1) Así que llegó en el mar [Francisco] empezó a ser perseguido por el tiburón.

(I2.B.2) Una noche, [Francisco] fue despiertado por un tiburón que lo jugó fuera del bote.

(I2.B.3) Como Francisco no percibió que el tiburón estaba tras del bote, fue atacado por él. El bote, el pájaro y Francisco fueron lanzados al aire.

(I2.B.4) Algunas horas después nada más se podía mirar, solamente el agua por todo lado.

(I2.B.5) En verdad el tiburón quería comer el pájaro que se quedaba en la cabeza de Francisco pero cuando el tiburón intentó comer el pájaro, tanto Francisco como su bote fueron jugados.

\section{INTERMEDIÁRIO II - C (I2.C)}

Total de alunos: 13

(I2.C.1) Los animales eran trenados para el juego y cuando vencían eran lider dentro de un clan, manada o tribu. Ya los humanos son distinguidos por toda la humanidad y son vistos como los mejores y como héroes. 
(I2.C.2) El juego humano es un fenómeno de la cultura transmitido por la educación y el juego del animal es puramente instintivo, relativo a su supervivencia dentro de un grupo.

(I2.C.3) Los juegos humanos no son sólo atividades instintivas: también son un fenómeno cultural. Por lo tanto, no se transmiten geneticamente, sino por la educación.

(I2.C.4) El juego humano es un fenómeno cultural, no es transmitido geneticamente.

(I2.C.5) A causa de eso [un accidente], por lo que sé, todas las funerarias están siendo solicitadas hoy.

(I2.C.6) ¿Los ataúdes fueron entregues?

\section{AVANCADO I (A1)}

Total de alunos: 8

(A1.1) Deseo que usted pueda encontrar una solución para mis problemas y que, así que llegue a mi sarcófago encuentre un mensaje de buenas noticias a fin de que mi vida pueda ser vivida otra vez.

(A1.2) Fuimos recibidos por muchos y variados insectos que paseaban tranquilamente y nos invitaban a bañarnos con ellos en el charco que era la piscina climatizada.

(A1.3) (...) El restaurante de primera categoría no era más que un balcón donde se podían comer bocadillos y beber tequilla.

(A1.4) Para terminar, nuestro coche fue estropeado por ladrones que nos quitaron todo lo que teníamos.

(A1.5) Les escribimos después de habermos sido robados por su agencia. (...) Todo lo prometido se trató de una grandísima mentira.

(A1.6) El aparcamiento era tan bien "vigilado" que nos chocaron el coche, rompiéndole todos los vidrios.

(A1.7) Así que me gustaría dejar bien claro mis protestos y también solicitar que me sea restituída una importancia en dinero, que sirva para pagarme los prejuízos que tuve, a que tengo derecho, por ter sido ludibriada. 
(A1.8) Nuestro coche fue estropeado en el aparcamiento. No habia vigia, pero habia ladrones.

(A1.9) Al visitar le museo nuestra orientación fue solamente el libreto recibido en su portaria, pues no habia guias para nos ayudar.

(A1.10) Exigimos de usted: a) la devolución de nuestro dinero; b) el reparo del coche, bien como la reposición de todo que le fue robado (...)

(A1.11) ¡Yo ahora sé que el aparcamiento es vigilado por ladrones, que nos roban las partes del coche!

(A1.12) Ustedes me vendieron un viaje organizado, pero, nada de lo prometido fue verdad.

(A1.13) Para passear nos fue ofrecido un coche con sus vidrios quebrados (...)

(A1.14) Voy a buscar mis derechos y exigir que el dinero sea devolvido.

\section{AVANCADO II - A (A2.A)}

Total de alunos: 8

(A2.A.1) El Sr. López es respectado por su profesionalidad pero hay quien le tenga mucha envidia. Juanito no es admirado por nadie, pero es muy gracioso y tiene muchos amigos.

(A2.A.2) Los médicos son vistos como "deuses", llenos de salud, sin problemas, pero ni siempre es así.

(A2.A.3) En un primer momento se puede pensar que no hay semejanzas en las profesiones de médico y changarín, sin embargo si buscamos las semejanzas con seguridad encontraremos algunas.

(A2.A.4) Incluso en situaciones que ponen en riesgo la vida de personas se puede apuntar semejanzas, pues un médico puede llevar a la muerte un paciente si no le pone la devida atención (...) Así que siempre se puede encontrar semejanzas, incluso donde no parece que ellas no existen. 


\section{AVANCADO II - B (A2.B)}

Total de alunos: 8

(A2.B.1) Son dos profesiones diferentes: los médicos aprenden con la teoría y con la práctica, pero lo mismo no ocurre con los changarines, que generalmente todo lo que saben es adquirido por la práctica.

(A2.B.2) No hay como valorar las diferencias de esas dos profesiones, solo se puede decir que en las dos hay personas contentas y no contentas. Pero hay algo que se puede afirmar: los changarines reciben menos dinero por su trabajo que lo reciben los médicos.

(A2.B.3) Las profesiones presentadas son muy distintas, pero de extremo valor para la humanidad.

\section{AVANCADO II - C (A2.C)}

Total de alunos: 10

(A2.C.1) El film es ambientado en Madrid, y empieza cuando Paz, tras haber suspendido en los éxamenes, es obligada por su padre taxista a trabajar en su profesión.

(A2.C.2) La razón para ese odio, que se convierte en asaltos, palizas y asesinatos a sangre fría, puede ser explicada por el miedo que emerge cada vez mais en grande parte de la Europa de hoy: el de que los extranjeros quiten sus empleos, se casen con sus hijos y destruyan sus vidas "perfectas".

(A2.C.3) Aunque existan personas así, los que son retratados en el film no convencen.

(A2.C.4)) Sin duda, se puede decir que la película tiene como eje fundamental una historia de amor que es afectada por el mundo del prejuicio y del racismo. Al final, la historia de amor se resuelve, pero el problema de los fascistas, naturalmente, no tiene una solución.

(A2.C.5) A pesar de toda la violencia presente en la película, el guión, escrito por Santiago Tabernero, se estructura alrededor de una historia de amor entre dos jóvenes, hijos de dos de los taxistas referidos arriba. 
(A2.C.6) Saura muestra en su obra su rechazo por todas las formas de prejuicio existente en su país hoy día, debiendo ser vista no solamente como una forma de denuncia de una dura realidad, pero también como una arma de transformación de la sociedad.

(A2.C.7) Además del tema, que es actual y real, y debe por tanto interesar al grande público, la película fue muy bien dirigida y los actores elegidos son bastante adecuados para los personajes que representan.

(A2.C.8) En conjunto, resulta una bella película que merece ser vista por todos.

(A2.C.9) Tras haber suspendido en los exámenes, Paz discute con su padre y es obligada a aprender la profesión de su padre.

(A2.C.10) Todo el tiempo se nos ofrecen situaciones incómodas y duras, que nosotros no gustaríamos de vivir pero que están alrededor de nuestras vidas.

(A2.C.11) La película hecha en 1996 está bastante oportuna y actual ya que discute el prejuicio contra lo diferente.

(A2.C.12) Paz y Dani, por ejemplo, se presentan como jóvenes que tienen dudas, hacen descubiertas, quieren se enamorar como cualquiera, pero son obligados a enfrentar situaciones que los madurese.

(A2.C.13) Después de dirigir musicales como Bodas de Sangre, El Amor Brujo y Flamenco, lleva al cine, con el guión escrito por Santiago Tabernero la película Taxi, donde aborda el tema de la intolerancia de los europeos con inmigrantes y otras minorías.

(A2.C.14) Cuando Paz descubre el mundo violento y asqueroso en que vive el grupo de taxistas, su relación con Dani es afectada y Paz empieza a correr peligro.

(A2.C.15) Paz, interpretada de forma magnífica por Ingrid Rubio, es el personaje más fuerte de la trama.

(A2.C.16) Saura por veces ha tratado en sus obras de muchos temas polémicos y reales, y sigue esta tendencia en este trabajo: un drama sobre la violencia ejercida por la gente de la calle, en la que por primera vez filma un guión ajeno.

(A2.C.17) No obstante, Saura consigue en esta película una mezcla de sentimientos negativos y positivos: por un lado se evidencia sentimientos de odio. Falsedad, mentira, indiferencia, prejuicio, sentimientos que son, en general, escenificados por los dos personajes Calero y Niño, que todo el tiempo se muestran como personas malas; por otro, queda muy claro tratarse también 
de una historia de amor, caracterizada por el romance entre los dos personajes centrales, Paz y Dani.

(A2.C.18) El lenguaje utilizado en la obra es casi siempre coloquial y algunas veces aparecen registros vulgares.

(A2.C.19) En verdad, ciertas formas de violencia mostradas en la película no son aceptadas por el autor.

(A2.C.20) Dani, aunque compartiese la misma opinión de los fachas, es bastante influenciado por las ideas de Paz, de quien se enamora. 


\section{Corpus C2}

Devido à extensão do corpus C2 (1.172 redações), decidi incluir aqui apenas as produções escritas mencionadas nos exemplos. Tal procedimento visa a evitar que a versão digital desta dissertação seja demasiado extensa e, portanto, de pouca praticidade para baixar e/ou consultar. Se houver interesse do leitor/pesquisador em consultar o corpus na íntegra, peço que entre em contato com a coordenação do Español en el Campus (EEC) (Área de Língua Espanhola e Literaturas Espanhola e HispanoAmericana do Departamento de Letras Modernas da Faculdade de Filosofia, Letras e Ciências Humanas da Universidade de São Paulo).

\section{BÁSICO I}

\section{EA100372}

Una profissión digna

Miguel Peres es bombero y vive en Madri con sus padres. Todos los dias va a trabajar en la corporación de Bomberos de su ciudad. Le gusta trabajar en está profissión por considerala utile para la población.

Cuando llamado para sus actividades hace con mucha atención y competencia. Ayer tuvo una llamada para socorrer una senhora en un bairrio lejano de Madri que estaba con problemas de vazamiento de gás. Miguel es un muchacho muy querido por sus compañeros de trabajo y también por las personas que son socorridas por él. Tiene como sus valores: el coraje, la buena vontad y eficácia en su labor. Al volver para su casa trás más un dia de trabajo sientese orgulloso y con el sentimiento de deber cumplido junto a la comunidad

\section{EA100614}

Sin título

Estoy ahora con la señorita Maria. Su apellido es Sanches y es conocida como: "la santa". Es una mujer mui recatada que no dicha duda de su devoción espiritual. Trabaja en una escuela como maestra y sus alumnos tiene miedo de ela. Su rutina es desaynar a las siete y después vá a la escuela para lecionar para los chicos y las chicas. En sus fines de semana le gusta ir al cine y después en la casa, solamente no domingo, le gusta banharse.

\section{EA100752}

Una película policíaca

La película que yo quiero hacer es una película de policíaca onde el protagonista es un policía joven, fuerte con vasto domínio de las artes marciais. Su nombre es Lopes, teniente Lopes y tienes un colega que es muerto en acción durante una investigación. Pero los bandidos no se limitan a ter matado su amigo pero queren cesar con la vida de toda su familia y de elle. Como los bandidos son muy influyentes, ellos conseguen 
culpar lo teniente pela muerte de su colega. Sin apoyo y buscado pela policía, el teniente tem que probar su inocencia y salvar todas las personas y acaba con la organización criminosa. Pero el cabeza del bando es preso y promete que un dia irá se vengar. Por su coraje y valor, es condecorado y vuelta para la corporación - Fín.

\section{EA100872}

"Ciudad de Sueños"

La protagonista de la película que estoy a guiar se llama Camila. Ella es una cantante que trabaja por las noches en el club "Silenzio". Es una joven de veintitres años muy guapa, morena, alta, delgada, tiene un nariz pequenito, ojos grandes, cuello largo, pelo negro, lacio y largo. Le gusta mucho engalanarse, llevar zapatos altos y coloridos, minifalda y gafas de sol, pero le encanta mismo las semijoyas; posea una colección. Adora los disfarces y las pelucas.

Camila vive en San Francisco, con su tia Elza, en una casa enorme. Se levanta al mediodia, toma una taza de café, hace el almuerzo pronto. Come a las tres con su tia que llega del oficina a las dos y cuarto en punto. Lava los platos, bañase, afeitase y sale de casa. A las seis de la tarde usa el coche de su tia para desplazarse al club, donde trabaja hasta las cuatro y media de la mañana. Vuelve a casa, se acuesta a las cinco. No trabaja los domingos, tampoco los lunes, cuando va de compras, o al cine con sus compañeros.

Camila sueña ser protagonista de una película guiada por el guionista David Lynch.

\section{EC101442}

Sin título

Emilio Martin Valdez es un hombre muy gordito y extraño, tiene bigote, una voz roca y un rostro de pocos amigos. Una inteligencia fantástica, astucia y cautela. Este es el perfil perfecto a la profesión de policia . Una cicatriz en su cuello haz de ello un persona muy temida por todos, resultado de un cambio de tiros con traficantes del barrio de Cuesta Azul en Cali, Colombia. Valdez tiene una caracteristica muy admirada por todos - el faro por ladrones, se destacando en las investigaciones mas complexas. Es el principal policia de la Delegacia de Operaciones Especiales de la ciudad de Bogotá.

Sus caracteristicas son consecuencias de muchos estudios y de una vida muy dedicada al trabajo y también por una aficción que le gustan mucho - las películas de ciencia ficción donde los personagens son como misterios a seren desvendados.

Despierta por las 6 de la mañana y simpre haz una reza a San Pablo. La protección de su familia y tuya es de gran importancia porque los peligros de la vida y de su profesión son muy numerosos. Por las 7 desayna con su esposa Constanza y su hijo Miguel, después despede de ellos con un beso muy cariñoso, pero el temor de su profesión deja siempre una duda de que un día no volverá.

Cuando llega en la Delegacia cumplimienta sus compañeros de trabajo y su jefe, el delegado Juan Domingues. Después sali con tu pareja, el policia Mendoza en las calles de Bogotá. Cuando oyen el sonido del radio luego se ponen en alerta para los peligros que los ciercan. 
A las 12 vuelve a la delegacia para almonzar y esta es una buena hora para hablar con su esposa. Mientras come juga al ajedrez con su jefe como un ejercicio de estrategia militar.

Ni terminan de jugar y comer y una llamada los interrompen. - ¡Fuerza total!, grita un policial y Valdez sali con otros policiales hacia al punto de la llamada.

Terminada las tareas del día todos vuelven a sus casas y Valdez siempre camina hasta al colegio Santa Edwigenes encontrar con su hijo Miguel. Cuando llegan en casa, su esposa ya los esperan con una cena muy deliciosa. Es un momento encantador en la vida de la familia de Valdez, donde todos comparten sus experiencias y sus afectos.

\section{EC101472}

Sin título

Bueno, el protagonista es un hombre muy alto, de media edad, con pelo corto y grisáceo. Es un poquito gordo y tiene un vozarrón. Él parece ser muy serio, muy formal, pero en realidad es gay. Su problema es que como es un vendedor de oro, debe ser de buen parecer. Entonces sin embargo le gusta mucho su trabajo, a veces está muy triste porque sabes que todos son muy preconceituosos pero es una persona muy feliz e muy desordenado, hace que todos rían de él. Se despierta muy temprano, a las siete, desayuna así que se levanta, se ducha, cepilla los dientes, peina muy bien el pelo e va a trabajar. Él tiene hora marcada con sus clientes e llega a casa de la primera a las ocho e media. Y así es, por todo el día está a caminar de una casa a otra, para vender su oro. Vuelve a su casa a las ocho o más, porque siempre encuentra una rica que quiere ser atendida sin marcar hora. No tiene una hora exacta para el almorzo, cuando llega en casa trata de cenar e ducharse porque sus amigos están le esperando para salieren de copas y de tapas. Cuando salen juntos se visten con cosas coloridas, mucho accesorios y con mucho maquillaje. Le gusta mucho las películas de le hagan llorar, le gusta leer romances y estar con sus amigos.

\section{EC101542}

Sin título

Se llama Juan y vive en Córdoba con su novia. Todos los días se levanta a las cinco y media y desayuna en casa. Luego va a trabajar. Es bombero. Por la mañana trabaja en cuartel. Por las tardes va en parque hacer un paseo

Vuelve a casa a las siete por la noche cena con su novia a las ocho en punto y se acuesta a las diez.

La despierta a las cinco y media, se levanta a las seis, desayuna a las seis y media, empieza a las siete, como al mediodía y media vuelve a las cinco por la tarde, por la noche va al parque hacer una caminata, un paseo. Vuelve del parque a la ocho, cena a las nueve se acuesta a las diez.

Elle se dedica en salvar-vidas, trabajo mucho humano, bondadoso.

Él es bombero gusta caminar, nadar, leer, ver una partida de fútbol

Elle es un hombre fascínate, es muy alto, delgado, pelo curto alisado, ojos verdes, boca carnosa.

"Un bombero atenle un llamado, una mujer muy guapa dialoga.

- ¿Buenos días, señora López, que tal? 
- ¿Yo voy bien señor, qué pasa?

- ¿Permiso, señora, su marido está?

- ¡No señor!

- Que óptimo. ¿ Puedo entrar, señora?

- ¿Que pasa?

- ¿ Bien, tiene fuego en su casa?

- ¡No señor!

- Entone quien sabe en su jardín?

- Bien señora , soy un hombre , bien solitario, preciso hablar con una Pessoa encantadora, educada y dócil..

- Señor, soy una mujer casada. No tiene problema

\section{ED101722}

"Hercule Poirot en Madrid"

Hercule Poirot es un detective particular belga. Él es bajito, usa un vasto bigote e una galera negra en la cabeza. Es una persona muy agradable, sin embargo quieta y pensativa. Es muy conocido por su argucia, su capacidad de resolver misterios y por su sistematización al hacer sus tareas.

Él no tiene su oficina particular. Cuando hay alguno caso a se resolver, generalmente él se queda en la casa onde hay ocurrido el crimen.

No le gusta nada cualquiera desorganización, sea en su trabajo, en su casa y ¡hasta en la forma como quedase su bigote! Pero es este su rasgo perfeccionista que le ayuda generalmente a resolver sus casos.

Él solea levantarse temprano y desayunar mientras lee el periódico del dia. Después va a hacer su higiene personal. Solea leer la correspondencia y sae a la comisaría de policía donde ayuda su amigo Inspector Jap.

En esta película, Poirot va a viajar por Madrid, cuándo ocurre un crímen en la casa del embajador inglés. Este llama Poirot para resolver el crímen.

\section{BÁSICO II}

\section{EB200284}

Sin título

En el año pasado he ido a visitar Ouro Preto. He ido con dos amigos. Hemos ido a visitar las iglesas antiguas, los museos, hemos conocido restaurantes muy buenos, que tenías comidas muy saborosas.

Hemos quedado en un hotel simples pero muy confortable. A mi me gustó mucho visitar Ouro Preto, una ciudad antigua, con muchas histórias y lugares encantadores de se conocer.

Yo creo que no final deste año voy viajar a Pantanal, me gustaría mucho veer la vegetación, los animales, los ríos con aguas cristalinas. Yo creo que voy hacer paseos 
turísticos para conocer un poco mas sobre este lugar, que para mí, me parece ser muy excitante.

\section{EB200312}

Diario de viaje a Sedna

Lunes (14-V-2004)

Quedamos conociendo las características ambientais (clima, tamaño...) de Sedna pórque la viaje empezará por la mañana de Martes.

Pienso salir del nuestro planeta con mucha curiosidad, tranquilidad y un poco de miedo del desconocido.

La nave espacial ya fue revisada en la semana pasada y el equipo ya recebió entrenamiento.

\section{Martes (15-V-2004)}

La nave ha salido de la Tierra a las 6:30h con algunas dificuldades de arrancar, pero nada serio.

Era 18:30h de la noche 12 horas después de la saida de viaje, ya estabamos alojados y con mucha ansiedad, llegamos en Sedna somente al amanecer.

Miércoles (16-V-2004)

Hemos llegado a Sedna hoy al amanecer y empezamos a caminar por cerca de la nave.

El clima estaba muy caliente y el cielo rojo.

Durante todo el dia conocemos sólo una fuente de vida, una rosa de color gris en uno llano de piedras.

Jueves (17-V-2004)

Nos hemos despertado a las siete con el despertador de la nave, desayunamos y salimos al trabajo.

Nadie ha encontrado cosas incomúns, sino otra rosa gris en llano de piedras.

El cielo también continuo rojo como ayer.

Viernes (18-V-2004)

Hemos salido de la nave, nuestro abrigo, por la noche (hora de la Tierra) para vir al cielo y conocer a Sedna en otro horario.

Hemos volvido para nave, desayunamos y nos acostamos.

Sábado (19-V-2004)

En este día ha terminado el tiempo de la viaje y nosotros ya habíamos conocido todo el planeta Sedna, él es muy pequeño.

No hubo nenguna novidad registrada, sólo las rosas gris en llano de piedras y el cielo rojo veinticuatro horas (en el tiempo de la Tierra).

Tuvimos algunos dibujos y pocas informaciones aunque muchas dudas y preguntas sobre la origen de la vida y suyas manifestaciones.

Domingo (20-V-2004)

Hemos salido de Sedna por la mañana y ahora son 18:30, estamos cansados y con mucha añora de mi pueblo y de la Tierra. 


\section{EB200492}

Diario de Viaje

Domingo (10-07-2050)

Hemos llegado a Sedna alrededor de las dos de la tarde (hora de la tierra), dos horas después del programado. La nave espacial no ha tenido averias, pero hemos tenido dificultad en la aproximación de Sedna a causa de su camada atmosferica. Ha sido muy difícil penetrarla.

Lunes (11-07-2050)

Nos hemos despertado a las ocho a causa de un ruido muy fuerte. He puesto la ropa especial y he salido del abrigo a ver qué pasaba y hemos encontrado una cráter hecha por un meteoro. He caído muy cerca de nuestra nave y he tenido un sobresalto. A las once hemos empezado la primera misión de reconocimiento. Hemos encontrado un río muy largo, una vegetación abundante y un terreno muy accidentado. ¡Pero todo es diferente! La agua es negra y la vegetación es muy variable en altura y tiene tonos de color cinza. Hemos encontrado también algunos animales. Todos muy pequeños, algunos con dos piés y otros con tres. Es normal ellos teneren dos cabezas y solo un ojo en casa. Pensamos que es para su protección. Cogemos amuestras de todo que encontramos y volvimos a la nave, donde empezamos la clasificación y arquivamento de todo que colectamos.

Martes (12-07-2050)

Hemos salido a las 9 y hemos ido para el otro lado, dirección sur. Encontramos una gruta muy grande donde hemos decidido cambiar la nave espacial de lugar para ají, porque estaremos más seguros y llamaremos menos atención. Hoy hemos encontrado más especies de animales, algunos que viven en comunidad, aparentemente herbívoros. Hemos visto también un gran animal con cuernos gigantes y una extensión de su boca que parece una trompa. El es carnívoro y nos hemos tenido que esconder, para no sermos comidos.

Miercoles (13-07-2050)

Hoy hemos decidido explotar la gruta donde estamos aterrizados. ¡Es muy grande! Hemos encontrado algunos objetos que parecen indícios de que alguno tipo de vida inteligente vivió allí. Puede já estar extinta porque el sitio parece abandonado. Pero los objetos parecen ser muy elaborados, aparentemente usados para la caza y también hay algunos apuntes que parecen ser un control de algo a través de un lenguaje que no hemos podido identificar.

Jueves (14-07-2004)

Hoy hemos cogido nuestro coche espacial y hemos ido más lejos. Hemos encontrado sítios muy fríos, con mucho hielo y no pudimos reconocer casi ninguna forma de vida animal, ni tampoco vegetal. No hemos podido ir mucho más lejos porque habían muchos locales donde el hielo estaba muy delgado y podríamos caer con el coche. No hemos podido arriesgar. 
Viernes (15-07-2050)

Hoy salimos más tarde, a la una porque ha ocurrido una tempestad de arena que nos ha empedido de salir. Hemos hecho algunos experimentos con las amuestras de água y hemos descubierto que la agua es compuesta de hierro en gran proporción, tiene niveles de oxigenio muy bajos y solo se evapora a 130 grados.

Hemos estado en una visión más clara de nuestro rededor. Hemos visto un sítio diferente. Puede ser una comunidad porque parece una aglomeración de abrigos. No sabemos al cierto pero parece un ambiente artificial, lo que demostra que hay vida inteligente y organizada. Cuando volvíamos hemos oído un barullo y algo se movió. Hemos averiguado pero no hemos conseguido descubrir lo que era.

Sabado (16-07-2050)

Hoy vamos explorar la comunidad que vimos ayer. Estoy muy contenta porque es la descubrimiento más sorpreendente de la viaje y mañana vamos a volver a la Tierra. Por eso és mucho importante esa ultima expedición.

Hemos ido hasta la comunidad que vimos ayer. Hemos dejado el coche cien metros lejos. Habían muchas casas de piedra. Eran como los iglús del pólo norte en la tierra, pero hecha de piedra. En un determinado momento yo me he apartado de mis compañeros porque he decidido entrar en una casa que parecía vacía. En este momento he oído un gran estruendo. Fui a ver lo que pasaba a traves de la ventana. Habían muchos seres raros y se quedaron alrededor de los otros pesquisadores. Ellos eran muy delgados, tenían grandes ojos azules, su piel era manchada, muy oscura, tenían una cola con espinos en su punta. Eran muy peludos, parecía que tenían también una especie de cartílago en sus espaldas como los pez.

Estaban muy nerviosos y hablaban una lengua muy rara. Mis compañeros no sabían que hacer. Cuando me he dado cuenta que todos estaban en peligro he decidido escapar. He cogido el coche y he volvido a la nave espacial. ¡Pero no sé lo que pasa! ¡El radio no funciona! ¡No puedo comunicarme con la Tierra! ¡Por Dios!, ellos estan cerca, iiiestán llegando!!! ¡Socorro!

\section{EB200602}

Diario de Viaje

Domingo (10-V-2050)

Hemos llegado a Sedna alrededor del mediodía (hora de la Tierra). La nave espacial no ha tenido averías y vagarosamente el trípode de sustentación toca en suelo del planeta.

Lunes (11-V-2050)

Nos hemos despertado a las ocho a causa de un ruído muy forte. He salido del abrigo (un abrigo más adecuado para la situación pero muy semejante del abrigo del esquimal) a ver que pasaba y nos asombramos al mirar un animal (cabalgadura) muy grande y lindo, muy calmo, sin agresividad.

Martes (12-V-2050)

Nos hemos começado la exploración del planeta con la ayuda del animal (nosotros escogemos el nombre para él= Amigo) que demonstraba entender lo que hacíamos. 
Miércoles (13-V-2050)

Hemos encontrado un suelo muy semejante al de la Tierra, caminos como terruños, agua cristalina, unas árvores, más nada tan sorprendente como el oxígeno atmosférico, dispensando el uso del ropage convencional.

Juenes (14-V-2050)

Nos hemos despertado muy tranquilos, Amigo estaba esperandonos quieto; nosotros salimos y juntos empezamos nuestro trabajo. En el lado opuesto del abrigo, caminando dos horas, increíblemente nos quedamos frente a una visión que, a la Tierra nos llamaríamos de "las siete maravillas del mundo". Una grande ciudad, una cadena de montañas al fondo, como un marco de un cuadro, como una pintura de un maestro de la arte.

Viernes (15-V-2050)

Volvendo al mismo sitio luego por la mañana, nos hemos sido recibidos con los brazos abiertos, por un batallon de seres semejantes los hombres terrícolas, uniformes como trajes, pero, los piés estaban por arriba del suelo vinte centimetros, haciendonos entender la superioridad de vida, de conocimientos, de ética y de acatamiento a los seres de menor evolución.

Sabado (16-V-2050)

Como cicerones, nuestros nuevos amigos exibiran las novedades, las innovaciónes desconocidas en la Tierra, el adelantamiento de la medicina, de la cultura, de la ética, del cuerpo más sano, menos sujeto a las enfermedades tan comunes en nuestro mundo (Tierra).

Domingo (17-V-2050)

Continuando nuestro espanto, aprehendemos que, en Sedna, se camina sin poner los piés al suelo, se viaja con apenas una orden del pensamiento y se usa una nave espacial para sitios muy lejos. La alimentación es ligeira, nada de carnes, solamente una comida que a nosotros nos parecen legumbres, todo muy apropriado al cuerpo más diáfano. No hay agresividad entre los habitantes, no hay robo, no hay asesinato, las parejas viven la vida juntos ( como los casamientos que conocemos), sin peleas y también sin cambio de parejas.

Lunes (18-V-2050)

Ha llegado el día de nuestro regreso. Despedirse del Amigo fué dificil, de los otros también. Agradecemos la hospitalidad, con la nave en movimiento, miramos todos haciendo señas para nosotros. La nostalgía ya apretándonos el corazón, la nave partió, los ojos se quedaran atentos ayá lejos Sedna cambiarse en un puento minúsculo.

Ahora, a camino de casa, nos quedamos a filosofar con respecto a todo que vimos y la conclusión más patente, más lógica, solamente podría ser la siguiente:

1- ¡Hay que mejorar nuestra Tierra!

2- ¡Hay que amarse más para vivir mejor!

3- ¡Tenemos que cambiar nuestro comportamiento, nuestra comprensión, para poder conocer una vida como en Sedna. 


\section{EB200881}

Biografía

Mi madre se llama Rita. Ella nació en la provincia de Paraiba en 1933.

Su madre murió un año después, por eso fue educada por sus abuelos.

En 1937, con cuatro años, ella y sus abuelos fueron vivir en Santos. Allí pasó su infancia entre bromas como escondite, cantar en círculo, hacer muñecas con espiga de maíz.

Estudió en una escuela de monjas hasta los doce años, donde aprendió a bordar, coser, cocinar y muchas cosas más.

Con doce años empezó a trabajar en una fábrica. En 1950 hizo el curso de enfermería y después trabajó en la Santa Casa de Santos.

En 1962 vino trabajar y vivir en São Paulo. Conoció su futuro marido, Luiz, en 1964 por medio de una amiga. Ellos se casaron en 1968 y vivieron juntos até 1995, cuando se quedó viuda.

En la actualidad viaja siempre para la playa y participa de grupos de ancianos.

\section{EC201152}

Diario de viaje

Domingo ( 28-I-2038 )

Hemos llegado a Sedna a las dos, por la tarde (hora de la Tierra). Hemos despertado cuando la nave espacial aterrizó con dificultad. Los operadores del turno estaban desmayados y sus narinas habían sangrado un poco, pero pronto estaban bien y nos informaron que habíamos llegado a Sedna, el nuevo planeta del Sistema Solar. En este primer día nos quedamos en la nave para arreglar lo que se había desordenado.

Lunes ( 29-1-2038)

Nos hemos despertado temprano. En verdad poco hemos dormimos aquella noche.Tomamos nuestras píldoras de desayuno e nos preparamos para dejar la nave. Antes de salir empezamos a oír un sonido familiar. Como una música muy afetuosa que nos tranquilizaba. Para nosotros era mañana, pero no había el día. Era una noche azul, fria y brillante. Una luz nos hería los ojos. Como un sol de metal reluciendo en la noche. Despues nuestros ojos se acostrumbaron con esa luz y podían ver sin usar lanternas. Pero no había nada para ver aparte piedras ovaladas de diversos tamaños. Volvemos a la nave un poco desalentados.

Martes ( 30-1-2038)

Leímos de nuevo el informe sobre los seres que viven acá. ¿ Pero dónde estaban? ¿Qué música era aquella que tocaba siempre?. Volvimos al suelo del Sedna y empezamos a sacar algunas piedras para fotografiarlas y estudiarlas. Por la tarde nos quedamos en la nave haciendo informes sobre ellas, sobre la luz azul y sobre la música que se agrandaba. 
Miércoles ( 1-2-2038)

Hemos despertado con la voz de la Tierra. Podíamos nos comunicar con nuestro planeta de nuevo. i Que bueno! No estábamos solos.Cuando nos preguntaron porque hablábamos casi gritando, hemos notado que la música sonava más alto que antes. Ahora nos transtornaba más que encantaba. Redujimos el sonido del micrófono encuanto tentábamos descubrir el misterio de la música.

Hueves ( 2-2-2038)

Poco hemos dormido. Salimos de nave antes de amanecer. La noche era como el dia con su luz de plata. Pero no había más ninguna piedra, ni música. Fatigados y ahora más calmos, nos acostamos al suelo y dormimos un poco. Despertamos con ruidos estraños en nuestra nave. La puerta se abrió de pronto. Salió una figura rara que no caminaba, volaba y cantaba. Era pequeña y brillante con el pelo largo y rojo. Tan largo que barría el suelo destapando las piedras que estaban bajo la arena . He venido en nuestra direción, peró voló al espacio. Las piedras se transformaron en seres muy anormales, menores que el primero. Peladas, verdes y brillantes también, empezaron a cantar y a volar en su direción.

Viernes (3 -2 -2038)

No hemos dormido de nuevo. La Tierra intentaba hablar con nosotros. No contestábamos porque no sabíamos o que decir. La música ahora era terrible pues las piedras que estaban en la nave también se transformaron y cantaban más alto. Abrimos la puerta y ellas salieron. Afuera había una otra figura, mucho más alta que las otras. Estaba cerca de la nave y nos miraba. Nos acordaba un ángel titán, con el pelo de múltiple colores, corto y desastrado. Guapo y más brillante que todo. Podría ser el jefe. Con cautela nos acercamos de él para informaciones. De pronto la figura empezó a mover los diversos brazos que íban brotando de su cuerpo. Volvió la música, más fuerte y no se entendia nada.Despacio fuimos volviendo a la nave. Por suerte los seres estaban entretenidos con el probable jefe. Cuando vieron que estábamos partindo se quedaron nerviosos y empezaron a volar en nuestra direción. Por suerte nuestra nave era más ligera.

Sábado ( 4 - 2 - 2038 )

Hemos vuelto al espacio, ahora con tranquilidad, hablando normalmente. Sacamos muchas fotos de aquellos seres y del nuevo planeta, cuando huimos. Informamos a la Tierra que estábamos volviendo con informes muy interesantes. Teníamos un mes para prepararlos. Pero cuando miramos las fotos en el ordenador nos quedamos surpresos y aflitos. Sólo había piedras y más piedras para se estudiar. Las fotos que sacamos de la nave, cuando huimos, no exibían nada, porque los seres se fundieron a la luz azul. Sólo teníamos las fotos de las piedras antes de se transformaren en seres voladores que dejamos huir.

Desalentados seguimos nuestro viaje porque hemos fracasado, ya que no podemos probar o que hemos visto aquí. 


\section{ED201392}

Viaje a Sedna, el planeta desconocido: Diario de un viaje

\section{Domingo (13-05-2100)}

Hemos llegado a Sedna alrededor del diez horas de la mañana (horario de la Tierra). Es un planeta muy agradable, semejante a la Tierra (en las vegetaciones y en el clima) y me he quedado muy sorpreso por esto. Hasta ahora hemos visto varias especies de animales exóticos. Por la tarde he averiguado nuestra nave y está todo bien. Mientras averiguaba, creo que he percibido alguien o algo mirándome, pero no vi nada. He comunicado a los demás compañeros de la nave que se han quedado muy impresionados.

\section{Lunes (14-05-2100)}

Nos hemos despertado muy temprano, a las ocho. Hemos salido a las diez de la mañana y hemos hecho nuestra investigación. Mientras caminábamos hemos escuchado muchos ruidos. Hemos llegado cerca donde salía y hemos visto una ciudad maravillosa. Su pueblo figurase mucho a nosotros humanos, pero tienen tres ojos y no tienen pelos ni cabellos. Han vestido ropas sencillas, muy parecidas a los antiguos griegos, todos por igual. No hemos hablado con nadie pues nos no han visto. Hemos vuelto a nuestra nave.

\section{Martes (15-05-2100)}

A las nueve de la mañana hemos vuelto a la ciudad. Hemos entrado y nuestra presencia ha suscitado mucha admiración, pero miedo también. Todos han corrido hasta algo parecido a habitaciones (algo como grandes cuadrados y con sólo una puerta). Hemos visto que no hay coches, ni medios de transporte, y pela calle hemos visto como que plantas muy coloridas, unas más grandes, otras más pequeñas. Nadie ha venido para hablar con nosotros y, por esto, hemos vuelto a nuestra nave.

\section{Miércoles (16-05-2100)}

Nos hemos despertado a las nueve pues hemos escuchado muchos ruidos, voces. He salido de la nave y me he quedado muy sorpreso con la presencia de unos veinte "sednenses" inmóviles. He intentado hacer comunicación con uno de ellos, que se ha parecido su líder y, para mi admiración, he sido comprendido, pues he visto que tenían algo como un radio traductor de lenguajes universal. Después de muchas charlas he percibido que es un pueblo muy pacifico y, con mis otros compañeros, hemos hecho una gran amistad con ellos. Nos han hablado de sus costumbres, lo que suelen hacer, de su cultura, en fin, de todo su pueblo. He escrito todo esto en nuestra computadora. Nos han invitado a una fiesta al día siguiente, una fiesta típica donde han celebrado la buena cosecha de aquellos días.

Jueves (17-05-2005)

Nos hemos levantado a las once para la fiesta. Nos han venido buscarnos pues ha sido costumbre buscar a los invitados. Hemos llegado y, poco después, hemos dicho a todos que somos de la Tierra, un planeta muy semejante a Sedna principalmente en su vegetación, pero hoy no hay mucho más, pues el hombre de la Tierra ha destruido todo en nombre de su codicia. Todos se han quedados muy maravillados por todo esto. Después que hablamos, han hecho muchas danzas, con ropajes llena de colores, comidas exóticas que nos hemos probado. Hemos bebido un jugo que es una mezcla del 
zumo de una fruta típica llamada "cash" con una plantita llamada "aça". Hemos vueltos a la nave todos emborrachados.

Viernes (18-05-2100)

Hemos visto que es una civilización no desarrollada, pero muy bien estructurada. Puedo compararla a civilización azteca pre-hispánica. Han sido una sociedad matriarcal. Han adorado a nuestros conocidos sol y luna, a quien hacen ofrendas en sus templos, que nos han mostrado. Nos han mostrado sus plantaciones, muy semejantes a la tierra en la manera de hacer la siembra, pero no he podido identificar las cosas sembradas. Es un pueblo muy tranquilo y sencillo.

Sábado (19-05-2100)

He levantado a las siete de la mañana y he caminado por la ciudad. He hecho los últimos registros de esta civilización y mis demás compañeros han hecho registros de muchas especies de plantas, animales, insectos, vegetales, etc. Los sednenses nos han ofrecido muchas cosas, como ropas, algo como bisuterías, cosas de sus siembras. Hemos vuelto a la Tierra muy contentos con esta experiencia, pero particularmente he vuelto muy preocupado y pensativo, pues si una vez ya hicimos tantas cosas malas a los pueblos que habitaran a América pre-hispánica, ¿qué será hecho de este nuevo pueblo, tan sencillo y desprotegido como nuestros antepasados indígenas?

\section{ED201394}

Sin título

Ultimamente no he viajado, pero hace tres anõs viajé a Monguaguá con mi madre. Nos quedamos en un hotel lejos del centro de la ciudad, pero muy cerca de la playa.

Fuimos todos los días bañarnos en el mar. Visitamos a la iglesia del centro, fuimos a las ferias donde se venden muchas bizuterías y enfeites en general, pero nada importante.

Fueron días en que he descansado mucho, pues me puse muy nervioso con algunos problemeas ocurridos en mi trabajo, aun las muchas pruebas en la facultad.

Fueron días tranquilos, esto fue lo interessantedel viaje.

Desde que entré en el autobús hasta la playa fui escuchando musica, charlé con mi madre, pero nada arespecto de trabajo y si sólo chistes y juegos pues,, al fin, estaba muy agotado y aburrido.

He pensado para el mes de julio viajar con mi hijo, mi madre y mi novia hasta el interior de São Paulo, en una ciudad muy pequeña llamada Agudos.

Podré, así, presentar mi hijo a mis tíos, primos y amigos que viven lá, pues ellos no lo conocen. 


\section{INTERMEDIÁRIO I}

\section{EC300214}

Sin título

Em la primera foto hay una familia comemorando el cumpleaños de uno de sus membros. Hay globos adornando el salón y la madre es carinosa con todos.

Em la otra foto, los niños están cocinando y hacen una especimem de crepes. estan divertindose.

En las dos situaciones, se puede perceber que todos están felices, pero em la primera tal vez porque tenga adultos, todos están más comportados. Ya los niños que se quedaran solos, parecen divertirse mas que los otros.

\section{EC300282}

Sin título

En el Estado de São Paulo existe una pequeña ciudad que se llama Salto. Por presentar una gran variedad de la naturaleza, bellas flores y diferentes especies de pájaros, recibió el título de "Estancia Turística de Salto".

Salto se localiza muy cerca de la ciudad de São Paulo, cerca de cien kilómetros por la carretera Castelo Branco. Es también una ciudad vecina de Itu, una ciudad muy antigua conocida por tener objetos gigantes.

Salto está cortado por el río Tiete, que lamentablemente hoy, se encuentra contaminado, pero antiguamente era navegable y muchas personas nadaban en él.

Hay un parque llamado Rocha Mountoneé, porque existe una roca rosada muy bella, y dicen existir solamente en Salto y en França.

¡En la ciudad de Salto, ponte comprar muchos regalos para tus amigos! ¡ Salto tiene el mejor queso fresco de la região! Mas allá encontrarás mucha diversão y una población muy alegre y receptiva.

¡Ven! ¡Compre! ¡ Tu vas enamorarse por la ciudad de Salto!

\section{EC300402}

Anuncio Publicitario

Lejos 200 kilómetros de São Paulo existe una ciudad pequeña, pero muy bella y acogedora, llamada São Pedro.

Conocida por su hospitalidad, tiene muchos hotel hacienda donde se puede quedarse en contacto con la naturaleza, comer frutas del tiempo, hacer caminata, montar a caballo o entonces solamente reposar.

Las cascadas son un punto turístico mucho visitado por su belleza natural y São Pedro las tiene muchas.

Sus iglesias también deben ser visitadas poes son todas de lo siglo pasado y nos llevan a un contacto próximo con Dios. 
Todos los finales de semana se puede participar de fiestas tradicionales con comidas y danzas típicas de varias regiones.

Pero lo que mas llama la atención y atrae los visitantes son los bordados. Sao Pedro también es conocida como capital de lo bordado y allá se puede comprar todo que es necesario para una casa como cama, mesa y baño.

Venga y conozca una das mejores ciudades de lo Estado.

\section{EC300882}

Respirando História en Ipiranga

El barrio Ipiranga es uno de los barrios más antiguos y históricos de São Paulo.

Los conocimientos sobre la región de Ipiranga remontan a 1510 y el nombre, proveniente de lengua indígena, quer decir "agua roja o agua con barro", debido al riachuelo que corre por allí. Los primeros habitantes de la región fueron los indios Guaianazes.

El principal acontecimiento histórico que ocurrió en Ipiranga fue la Proclamación de la Independencia de Brasil, en 7 de septiembre de 1822.

Para representar ese importante acontecimiento, fueron construidos el Museo Paulista, el monumento del Ipiranga y el parque de la Independencia; puntos turísticos del barrio. El museo,con grandiosas proporciones posee objetos indigenas, mobiliario, armas, pinturas, ferramientas, coches, vestimentas y muchos otros objetos. Ya el parque, recientemente reformado, posee bellos jardines.

También merece una visita el Museo de Zoología que dispone de animales taxidermizados expuestos y de una biblioteca con más de 73.000 volumenes especializados en zoología.

No deje de visitar el barrio Ipiranga y conocer parte de la história de São Paulo y de Brasil.

\section{EC300892}

El Paradoja Butantã

El Butantã surgió al final de siglo XVI como un portal de salida de los exploradores de la ciudad de São Paulo en busca del oro en Minas Gerais. Él nació en una área de nava y en la lengua indígena llamaba "tierra dura". En 1799, las tierras de esa región fueron arrendadas y transformadas en una hacienda llamada Hacienda Butantã. Por estar lejos del centro de la ciudad, esa hacienda fue comprada de su dueño, Dr. Arnaldo de Oliveira Barreto, en 1898, para la instalación de un instituto para la produción de un suero contra la peste. Participaba de la equipo de médicos, el científico y médico Vital Brasil.

El barrio fue desarrollando a partir del Instituto Butantã y hoy es un ejemplo del paradoja de São Paulo pues en el conviven áreas de adinerados, de clase mediana y pobres.

Eficaz en sus investigaciones sobre venenos de animales ponzoñentos, el Instituto Butantã es famoso por la produción de vacunas y por la exposición de culebras, arañas y alacranes.

La Ciudad Universitaria de la Universidad de São Paulo es otro sitio de gran importancia en Butantã. La Universidad de São Paulo es la mayor instituición de 
enseñanza universitario del Brasil y en la gran extensión de la Ciudad Universitaria hay 23 unidades de enseñanza, radio, televisión, periódico, bancos, correo, cafeterías, gasolineras, hospital, hospital para animales y mucha área arboleda.

\section{INTERMEDIÁRIO II}

\section{ED400214}

Sin título

Los turistas brasileños son muy alegres y festivos, así es que para agradarlos hay que ser informal y cariñoso. A ellos les gusta que se use expressiones como: "(mi) cariño", "(mi) precioso", etc.

Los brasileños costumbran saludar a todos con besitos y abrazos. Es necesario que no os asustéis con esas manifestaciones.

Para agradarlos debéis conocer un poco de su música y nunca debéis llamar la capital del Brasil de Buenos Aires.

Hay que conocer también, un poco de su cultura, y por último és necesário que elogiéis sus playas.

\section{ED400273}

Sinopsis de la película: "Closer - Cerca demasiado"

"Closer" es la más nueva película del grande director de cinema Mike Nichols, desde su último trabajo "Angels in America". La película estrenó en Brasil en janeiro de 2005 y sigue siendo un gran suceso de público.

Los personajes son vividos por Julia Roberts, Jude Law, Natalie Portman y Clive Owen. Juntos ellos forman dos parejas que en determinado momento de sus vidas si encuentran, siendo que del encuentro surgen nuevas tramas. La historia tiene como escenario los paisajes de Londres.

"Closer" trata de las historias de amor que normalmente ocurren en nuestras vidas, pero las historias no son contadas como se fueran un "cuento de hadas", la película muestra los problemas que las parejas enfrentan todos los días y como es difícil la vida a dos.

No hay cenas mucho calientes, no se muestran cenas de sexo, la atención del público es llamada pelos diálogos intrigantes y irónicos de los personajes. Además los misterios de la película, con traiciones y algunas mentiras, son otros puntos que hacen de "Closer" un gran suceso.

\section{ED400281}

Sin título

!Ring!

- Joana. ¡Buenas tardes! ¿En que puedo ayudarte?

- Hola, Joana, acá es Manoela. Me gustaría saber a respecto de un anuncio que he visto en el periódico. 
- Sí, claro.

- ¿O que exactamente ustedes buscan?

Buscamos personas organizadas, independientes y que cumplan con los deberes establecidos.

- Sí, comprendo.

- No es necesario experiencia anterior, sólo se requiere buena capacidad de comunicación.

- ¡Vale! Creo que tengo esas características. He leído que puedo trabajar en casa, ¿Cómo eso funciona?

- No hace falta venir acá al escritorio todos los días, tu puedes trabajar en su casa también.

- Bueno, pero, ¿ Qué tengo de hacer?

- Es una cosa muy simples. Tendrás de ser cobaya en algunos exámenes.

- ¿ Perdona? ¿ Qué tipo de exámenes?

- Tendrás de probar la eficacia de algunos fármacos, de algunos experimentos científicos, entre otras cosas.

- Correcto, pero eso no es lo que yo estoy buscando en el momento.

- i No tengas miedo! Todos los exámenes son controlados por especialistas. Nada de mal va a ocurrirte. Además, es una buena recompensa la que vas a ganar.

- Si, estoy precisando de un bueno pago, pero...

- Pensé bien..

- $i$ Ya he pensado! No es miedo, solamente eso no es lo que estoy buscando. Gracias.

\section{ED400701}

Sin título

- ¡Hola! ¿78541221?

- Si, "Confecciones Lola".

- Buenas tardes senõr, leí un anuncio en el periódico "El Planeta", me puse muy curiosa, y necesito de algunas informaciones.

- Dígame. ¿Cuáles son sus dudas señorita? Soy Pepe Herrera, director en esta empresa.

- Sucede que leyendo este anuncio me quedé muy interesada y me gustaría saber cuál es realmente este trabajo.

- Acá, tenemos una confección de ropas donde vendemos y distribuimos para muchas tiendas. Existe el sitio donde se fabrica las

piezas . El anuncio en cuestión se trata de la necesidad de completar nuestro equipo de modistas.

- Muy bien, yo soy modista, conozco un poquito de informática y, ya trabajé cómo vendedora.

- ¡Qué bien! Es la persona indicada para trabajar con nosotros.

- ¿Puedo saber cómo podré ocupar esta vacante?

- ¡Mira!, tienes que hacer su curriculo, enviarlo a nosotros para que hagamos una evaluación, y después de la entrevista encuesta, si pasas, será un placer tenerla cómo parte de nuestro equipo.

- ¿Cuáles el horario que se debe cumprir?

- Si elige, su casa para trabajar, el horario es usted quien decide, si quiere trabajar en nuestra oficina el horario es de las ocho de la mañana hasta las dieciocho horas, con dos 
horas para el almuerzo, y quince minutos para la merienda de la tarde, en horario a combinar.

- ¿E el sueldo, cómo si queda?

- En conformidad con el anuncio, recibirá un fijo de 2000 "reais", y un incentivo de 100

"reais", caso supere la cuantidad de piezas acordadas, en hasta treinta por cento.

- Estoy muy interesada, y me quedaré muy contenta, caso sea bien sucedida. Haré todo lo posible para conseguir este trabajo.

- Muy bien, la espero a las nueve horas, en la próxima semana para una encuesta, en el viernes próximo, 26 de mayo.

- Muchas gracias, señor Herrera.

- Hasta la vista.

\section{ED400744}

Sin título

Primeramente, tiene que hablar muy bien el portugues; hace falta conhecer el Brasil, pues tendrás mas assuntos con los turistas brasileños.

Como todos los saben en el Brasil las personas son muy simpaticas y amaveis, tiene que tratarlos muy bien, porque pueden ser un povo muy bueno, pero todos adoran ser bien tratados.

No puede hacer diferencias entre raças, religião, etc pues en el Brasil hay muchas raca distintas y hablando algo male sobre eso, puede hacer una grande gafe

Atravez desto manual esperamos que todos los brasileños sean benvindos en todo el mundo.

\section{AVANZADO I}

\section{EE500021}

Carta formal

São Paulo, 25 de noviembre de 2005.

Al responsable por el Sector de Calidad y Atención al Consumidor

Por la presente carta deseo expresar mi indignación y mi descontentamiento con vuestra empresa, de la que yo soy comprador regular desde hace muchos años y ahora, para mi sorpresa, tubo el desplacer de notar que no está inmune a incidentes desagradables.

El día 22 pasado me compré en el supermercado de mi barrio un bote de mermelada con el rótulo de "La finca de los dioses", así como lo hago todos los meses. La tenían en tres sabores distintos, de los cuales escogí el de fresas, mi favorito. El bote estaba cerrado, con el lacre de la empresa, donde se puede leer la información de seguridad "no la compre si ya se rompió el lacre”. Seguí la instrucción del fabricante, conferí el lacre y me lo llevé a casa, donde lo guardé en un armario adecuado para estos productos, con puertas. 
El día siguiente por la mañana me tomé el bote de mermelada para disfrutarlo en mi desayuno: rompí el lacre con una tijera, giré la tapa y con un cuchillo saqué un poco de mermelada para poner sobre el pan. De pronto mi mujer me tomó el pan de las manos antes que yo lo pusiera en la boca y empezó a revolver la mermelada con el cuchillo. Cuando finalmente encontró lo que buscaba, vi su cara de horror: una mosca grande y entera estaba misturada a la mermelada.

Creo que comprendéis mi enorme desagrado con esta situación: por el lacre cerrado, estoy cierto de que la mosca no entró allí en el supermercado o en mi casa, sino en la propia empresa "La finca de los dioses", durante su proceso de producción. Y vos pregunto: ¿Cómo puedo yo reaccionar delante de esto? Como he dicho, consumo las mermeladas de vuestra empresa desde hace mucho tiempo y siempre las admiré por su sabor y calidad. Pero no puedo aceptar ahora que mi familia esté sujeta a consumir un alimento cuyo origen no conocemos y que nos probó no ser muy confiable.

Les escribo para comunicar el ocurrido y no para ser compensado por ello. No sé si hay algún modo de cambiar la situación y pienso en quejarme también al Servicio de Defensa de los Consumidores.

De toda manera, quedo a la espera de vuestra posición sobre este caso.

Atentamente,

Sr. Alberto Díaz

\section{EE500403}

El crimen de infanticidio y las Leys en Brasil

En los Estados Unidos van a ejecutar a un condenado a muerte por infanticidio. Ese hombre ha confesado la autoría del crimen y se tiene pruebas contundentes e ello.

Aunque sea un crimen horrible aqui en Brasil nos es asi.

Segun el código penal brasileño, articulo 123 (cento veintetres), infanticidio es: matar bajo influencia do estado puerperal, su propio hijo, durante el parto o luego después. Detención de dos (2) a seis (6) años.

Entonces ese crimen solamente podria ser considerado un infanticidio, aqui en Brasil, si esto hombre tuvo consentimiento de la madre del niño, caso contrario no seria um infanticidio y si un homicidio (articulo 121 (cento vienteuno) del código penal).

Con respecto a esto y un otro absurdo es que la pena para homicidio es de reclusión de seis (6) a veinte (20) años.

En resumen la pena para aquél que mata a un niño es mucho más pequeña que para aquél de mata a un adulto.

En conclusión se deja aqui una cuestión. ¿En Brasil se deve adoptar la pena de muerte? ¿Puede un hombre que manta a un chico tener una pena más pequeña que aquél que mata a un adulto? ¿Podemos continuar con esta leys?

¡La unica cosa que se puede dicir de toda esta confusión es que nuestras leys son una vergüenza!! 


\section{EE500671}

\section{CARTA A LA ASOCIACIÓN DE CONSUMIDORES}

São Paulo, 23 de septiembre de 2005.

Señores responsables por la asociación:

Como compré un tarro de mermelada que, de modo sorprendente, vino acompañado de una mosca en su contenido; me tomo la libertad de enviarles esta carta con el fin de que ustedes tomen una providencia con relación al establecimiento comercial responsable por esa venta que considero, al mínimo, equivocada.

Por otra parte sé que la moda es el consumo de alimentos sin defensivos agrícolas y por eso poseen el riesgo de presentarem algunas imperfecciones. Sin embargo, una mermelada no pertenece a esa clase de alimentos ya que debe ser vendida en envases totalmente esterilizados, de modo que una mosca representa una afronta a la complacencia del consumidor y además nunca será vista como um animalito o un guzano propio de alimentos orgánicos.

Por lo tanto, exijo que hagan todo el posible para pequisar el establecimento en el cual compré esa memelada para que un acontecimiento de tal naturaleza no vuelva a ocurrir con otras personas.

Les agradezco anticipadamente.

\section{EF501083}

La pena de muerte: actitud bárbara

Miércoles, día 02, Sr. Carlos de Pasos Riony recibió una sentencia de muerte por infanticidio. Las pruebas son contundentes, él mismo se confesó y no hay duda de que es culpable. Por eso, debe morir.

¿Debe morir?

La pena de muerte no es una costumbre de todos los países del mundo. Hay países que defienden la prisión perpetua, otros que obligan los criminosos a hacer trabajos para la comunidad. Pero aquí en nuestro país la pena de muerte es legitima.

Sin embargo, eso no es comprensible en muchos aspectos. En primer lugar, España es un país católico, y la religión católica condena el homicidio. Por la visión de la iglesia, un hombre como Carlos es un "pecador"; si hay arrepentimiento, el pecador debe ser perdonado.

En segundo lugar, la actitud parece una paradoja: si creemos que un asesino (o sea, una persona que practica la violencia) debe ser punido - por esa violencia -, ¿cómo podremos proceder con la misma violencia que lo condena? ¿Cómo punir la violencia con violencia?

Por supuesto que Carlos debe ser punido por su crimen. Sólo no debe morir por eso. Ningún hombre debe morir, ni los criminosos. Total que, contra la violencia, prisión: no la muerte. 


\section{EF501114}

¿Por qué tener hijos y cuáles sus consecuencias?

¿Por qué tener hijos? Ésta es una pregunta dificil de se contestar. Tampoco lo se si quiero tener hijos, pero creo que, después de una certa experiencia de vida, las personas desean tener algo que les de un mayor significado para vivir.

Tener hijos es algo único, principalmente para una pareja que está casada (o viviendo junto) y planea una familia. Es una alegría increíble, pero también la mayor responsabilidad en la vida de una persona.

Las consecuencias de tener hijos son muchas. La vida de la persona cambia completamente: uno debe siempre pensar en sus hijos cuando desea hacer cualquier plano, "perde" sus oras de ocio, debe tener mucho más dinero, para gastarlo con educación, que creo ser lo más importante.

Además de eso, es muy importante que los padres estén preparados para dar mucho amor y cariño, porque esto es fundamental en la vida de un niño.

Para terminar, pienso que la responsabilidad de se tener hijos es muy grande, pero la felicidad que ellos traen es mayor. Espero un día estar preparada.

\section{EF501123}

¿Qué remedio?

El 29 de Junio será ejecutado el peligroso asesino Juan Pablo Gutiérrez, a causa de la muerte de más de nueve niños, en la Ciudad del México. Disfrazado de payaso, Juan los engañaba prometiéndoles dulces, boletos para el cine y paseos en moto. La mayoría de las víctimas tenía menos que cinco años y era de familia rica.

Los cuerpos fueron encontrados detrás del mercado "Buen Precio", todos dilacerados y con un billete en la boca, que decía: "No quedará vivo ni un hijo del Capitalismo".

Juan Pablo, culpable asumido, se justificó con un cliché: "hice para salvar el mundo". No es necesario mucho para darse cuenta de que hablamos de un psicópata y fue lo que también concluyeron la policía y los médicos. Luego de eso, Juan fue juzgado y condenado a la penalidad máxima.

Aunque las personas sabían de todas las atrocidades por él cometidas, más de cuatro mil mexicanos de todas las partes del país vinieran hasta Ciudad del México para defender el reo en nombre de los derechos humanos y piden que sea hospitalizado en el manicomio de la cárcel.

Está claro que por una parte ellos tienen la razón: no es correcto quitar la vida de una persona, aunque haya la intención de hacer justicia y matarlo no traerá los niños nuevamente a sus padres. Pero por otra parte, sabemos que un manicomio no lo hará sano y que él no podrá volver a las calles como una persona común. Y si vuelve, aunque los médicos digan que está sano, ¿quién se acercará de él? ¿Quién le dará un empleo? ¿Quién conseguirá olvidarse de todo lo que hizo?

Así que se quedará aislado de la sociedad y su enfermedad volverá, poniendo todos en riesgo pues, libre, podrá repetir sus errores y incluso cometer otros peores. Entonces uno puede decir: "que siga encarcelado en el manicomio hasta la muerte". Suena bonito, pues no le quitarían la vida y él no amenazaría la sociedad. Sin embargo, no es justo con el pobre ciudadano que tiene todo el sueldo consumido por los impuestos, muchos de estos usados para mantener criminosos en la cárcel sin que trabajen, con comida y salud 
garantizados por un gobierno que no proporciona eso a su pueblo. Total que no hay otro remedio sino matarlo. Además de eso, el ejemplo hará que las personas piensen mil veces antes de cometer errores tan terribles como él los cometió.

\section{EF501134}

¿Por qué tener hijos y cuáles son sus consecuencias?

¿Por qué tener hijos? Esta no es una pregunta simples. Si, por un lado, muchas personas tienen ganas de ser padres, por otro hay que pensar en la educacion, en el futuro, en el dinero.

Creo que tener hijos actualmente es una tarea compleja porque es muy caro. Además, los padres tienen que trabajar y no pueden criarlos, sino que los niños son criados por canguros! Incluso hay muchas mujeres que intentan buscar canguros antes mismo de tener hijos para conocerlos mejor. Algunas veces los niños ni hablan con sus madres, solamente con los canguros.

En adicion, las escuelas son un gasto alto para la familia. Asi como las despesas con medicos, píldoras y otras cosas.

Por otro lado, tener hijos es una oportunidad unica en la vida de la pareja. Las persona que tienen hijos son muy felices y a ellos no les importa tener que pagar tantas cuentas. Sin embargo, las cuentas son altas, pero la felicidad es mas grande. Incluso hay medios de criar un niño sin gastar todo su dinero. Pero, también es necesario pensar en cual mundo este niño vivirá. No obstante, si hay amor en la familia eso ya es muy bueno y el niño puede ser feliz, independiente de todo. En comclusion, los padres tienen que decidir se deben o si tienen dinero para eso. 


\section{AVANZADO II}

\section{EF600075}

Sin título

El jueves pasado me lo pasé muy mal. Una de mis mejores amigas, Lucía, vino a decirme que hablaba mal de ella por toda la facultad. Por supuesto que me enfadé con ella, sin embargo mantuve la tranquilidad y simplemente le dije que alguien le estaba mintiendo al decírselo. Lucía no me creyó y dijo:

- ¡No pienses que podés librarte así tan fácil de la cuestión! Lo que escuché no eran chismes, eso lo tengo por cierto, porque lo escuché de gente confiable. Yo le contesté, muy despacio y tranquila:

- ¿Ah, sí? Pensaba que vos me consideraras a mí una persona confiable, pero ya veo que no es así.

Me parece que sólo entonces Lucía se detuvo un instante y pensó antes de hablarme. Se quejó de que no tenía como fiarse de uno u otro, a fin de cuentas, los dos eran gran amigos. Me decidí, entonces, por preguntarle:

- ¿Quién te dijo este absurdo, Lucía?; Decímelo, por fin!

Lucía no me lo dijo de pronto, estuvo dando vueltas por casi diez minutos, desculpándose, pidiéndome que considerara su enojo al oír que una de sus mejores amigas la traicionaba de esta manera. No me pude más aguantar y le pregunté una vez más quién se lo dijera. Al fin ella me contestó: Eduardo me lo dijo. Cuando Lucía oyó mi inevitable riza, me parece que se dio cuenta de lo que pasaba. Eduardo, mi ex-novio, le dijera chismes mentirosos, esperando que eso hiciera alejarme de una de mis grandes amigas. Así que todo quedaba resuelto: el espíritu vengativo de los hombres intentaba destruir una amistad.

\section{EF600121}

Mis vacaciones

Esta mañana yo llegué a la ciudad de San José del Agua Fría para aprovechar mis vacaciones. San José es muy formosa por sus playas y tiene un de los mayores aeropuertos de la nación. Es muy grande y el número de turistas. Miles de turistas llegan acá en San José todos los días.

Cuando fue buscar las maletas no las encontré. Primer pensé que había engañado del lugar. Pero luego vi que mis maletas se habían descaminado, por lo tanto fue asta la intendencia para tener ayuda.

- ¡Sr. Intendente mi nombre es Juan y estoy con un problema!

- ¡Buenos días Sr. Juan! Mi nombre es Gutierrez. ¿Cuál su problema?

- Primeramente tuvo mis maletas perdidas. Ellas fueran descaminadas y pelo que investigué ellas están en Tazmania. ¿Como voy tener mis vacaciones sen mis trajes? ¡También estoy sen plata alguna! ¿Cómo voy proseguir con mis vacaciones? Ya hable 
con muchas personas y ninguna he solucionado mi problema. La única información que tubo fue que las maletas están a camino da Tazmania. ¡Yo necesito de trajes y plata!

- Antes de nada vamos nos informar lo departamento de objetos perdidos. Así que tengamos echo eso usted tienes que henchir unos papeles. Después de henchido los papeles vos aseguro que recebarás la indemnización y o Sr. podrirá salir de compras y tendréis nuevos trajes y también toda su plata.

- ¡Entonces si tengo su palabra, vamos nos asta su oficina! Yo espero salir rápidamente puesto que estoy muy ansioso para conocer sus lindas playas e sus hermosas chicas.

\section{EF600495}

Sin título

Yo: Mira Lucia, Juan dice que yo hablé mal de tú porque no entendió nada.

Lucia: ¿Como? ¿No dijistes que yo no sé portarme bien en las clases, que soy boluda?

Yo: No, Lucia. Cuando las pruebas fueron entregues por los profesores de física y nadie sacó buenas notas, palavras muy duras fueron dichas por Mario. Y por eso ellos fueron rechazados por la clase. He comentado con Juan que la confusión fue precipitada por Mario y que no he entendido porque tú le ha apoyado.

Lucia: ¿¿Fui llamada de boluda por eso?

Yo: No, Lucia. Mira, la expresión boluda fue inventada por Juan. ¡Nunca la he dicho! Lucia: Vale entonces, pero se pasa algo, hablar conmigo antes que con otros, ¿vale?

Yo: ¡Vale! Y tú, no te creas en lo que dicen terceros. Cada uno entiende como le conviene. En ese caso, la situación fue mal interpretada por Mário. Tal vez no sea por mal, pero se no estabas allí cuando todo se pasó, no puedes concluir nada. 